UNIVERSIDADE DE SÃO PAULO

FACULDADE DE ODONTOLOGIA DE RIBEIRÃO PRETO

ANA CAROLINA HAWTHORNE

Avaliação comparativa entre enxertos alógenos e autógenos “onlay”. Estudo histológico, imunohistoquímico e tomográfico em coelhos 


\title{
AVALIAÇÃO COMPARATIVA ENTRE ENXERTOS ALÓGENOS E AUTÓGENOS “ONLAY”. ESTUDO HISTOLÓGICO, IMUNOHISTOQUÍMICO E TOMOGRÁFICO EM COELHOS.
}

\begin{abstract}
Dissertação apresentada à Faculdade de Odontologia de Ribeirão Preto - USP, como parte dos requisitos para obtenção do título de Mestre em Cirurgia e Traumatologia BucoMaxilo-Facial.
\end{abstract}

Orientador: Luiz Antonio Salata

Ribeirão Preto 
Autorizo a reprodução e divulgação total ou parcial da presente deste trabalho, por qualquer meio convencional ou eletrônico, para fins de estudo e pesquisa, desde que citada a fonte.

Catalogação da Publicação

Serviço de Documentação Odontológica

Faculdade de odontologia de Ribeirão Preto

Hawthorne, Ana Carolina

Avaliação comparativa entre enxertos alógenos e autógenos “onlay". Estudo histológico, imunohistoquímico e tomográfico em coelhos. / Ana Carolina Hawthorne ; orientador Luiz Antonio Salata Ribeirão Preto, 2010.

99p. : il., $30 \mathrm{~cm}$.

Dissertação (Mestrado) - Universidade de São Paulo, 2010

1. Enxerto Ósseo "Onlay". 2. Enxerto Ósseo Alógeno.

3. Enxerto Ósseo Autógeno. 4. Avaliação Tomográfica.

5. Avaliação imunohistoquímica. 6. Avaliação Histológica. 
Nome: HAWTHORNE, Ana Carolina

Título: Avaliação comparativa entre enxertos alógenos e autógenos “onlay”. Estudo histológico, imunohistoquímico e tomográfico.

Dissertação apresentada à Faculdade de Odontologia de Ribeirão Preto da Universidade de São Paulo, para obtenção do título de Mestre em Cirurgia e Traumatologia Buco-Maxilo-Facial.

Data da defesa:

Banca Examinadora

Prof. Dr.

Instituição:

Julgamento:

Assinatura:

Prof. Dr.

Instituição:

Julgamento:

Assinatura:

Prof. Dr.

Instituição:

Julgamento:

Assinatura: 


\section{DEDICO ESTE TRABALHO}

Primeiramente à Deus, por ter me dado essa grande oportunidade que é a vida, para realizar meus sonhos e objetivos. Por ter me dado saúde, coragem e principalmente força, para superar os grandes obstáculos que encontrei até este momento.

Aos meus pais maravilhosos Celso Arthur Hawthorne e Sonia Eli Zucoloto Hawthorne por terem me proporcionado suporte para realizar meus sonhos e conquistar meus objetivos. Agradeço o amor incondicional, a força, a segurança, a paciência a mim dada. Obrigada imensamente por serem pais presentes em minha vida. Amo muito vocês!

Ao meu grande irmão Celso Arthur Hawthorne Junior por compreender a minha ausência nesses anos que estive fora. Por preencher o espaço vazio na casa, minimizando a saudade dos nossos pais. Agradeço pelo amor, o carinho e a torcida até agora. Amo você! 


\section{AGRADECIMENTO ESPECIAL}

Ao meu orientador Prof. Dr. Luiz Antonio Salata por ter me aceitado como orientada em um momento muito difícil desses dois anos que estive nesta querida Universidade. Agradeço a grande oportunidade a mim dada. Sou imensamente grata pelos conhecimentos, a paciência, a disponibilidade, a dedicação e a amizade proporcionados.

Ao Prof. Dr. Samuel Porfírio Xavier, primeiramente pela confiança depositada na época de graduação. Agradeço com muito carinho a amizade entre nós e desejo que continue após essa etapa da minha vida. Sou grata pela oportunidade em conquistar este meu objetivo e pelos ensinamentos proporcionados.

Aos professores Prof. Dr Adalberto Luiz Rosa, Prof. Dr. Cássio Edvard Sverzut, Prof. Dr. Alexandre Elias Trivellato e Prof. Dr. Paulo Tambasco de Oliveira pelos conhecimentos e experiência transmitidos.

À Profa. Dra. Roberta Okamoto pelo carinho dado durante os experimentos em Araçatuba. Sou imensamente grata por todo esforço $e$ dedicação depositados para que os obstáculos encontrados fossem conquistados e os experimentos finalizados. 


\section{AGRADECIMENTOS}

Aos meus grandes amigos de mestrado, Gustavo, Luciana, Marcelo, Michel, Patrício, Renan e Rogério. Agradeço todos os momentos vividos nesses dois anos. Levo no coração a amizade conquista entre nós. Sentirei saudade de todos vocês!

Aos meus grandes amigos, Ana Paula, Luciana, Michel, André, Priscila, Pepato e Pando, por terem participado dos dois anos de especialização. Foram anos maravilhosos e cheios de cumplicidades. Obrigada por fazerem parte de uma etapa da minha vida.

Agradeço às pessoas que foram fundamentais para a realização deste trabalho, Paulo Esteves Faria, Ariovaldo Theodoro, Antônio Sérgio Aparecido Mesca, Antônio Massaro e Vani, pela enorme ajuda, disponibilidade e dedicação. Em especial aos meus amigos Patrício, Luciana, Maria Amélia e ao meu pai por estarem disponíveis para me ajudar nas cirurgias.

Às grandes amigas e secretárias do Departamento de Cirurgia $e$ Traumatologia Buco-Maxilo-Facial e Periodontia Tatiana Angeli Fernandes e Aparecida Dulce de Oliveira Negretti, agradeço a amizade, a paciência, as grandes ajudas. Vou levá-las sempre no meu coração. Obrigada por estarem sempre à disposição. Sentirei saudades!

À Adriana Almeida pela amizade! Agradeço de coração a ajuda, a paciência, a disponibilidade dada a mim. Obrigada pelos conselhos! Sentirei saudade das horas passadas no laboratório. 
À FAPESP, Fundação de Amparo à Pesquisa do Estado de São Paulo, pelo suporte financeiro que possibilitou a execução deste projeto e pela concessão da Bolsa de Mestrado.

À FORP - USP por toda estrutura e acolhimento encontrada aqui, que me possibilitou adquirir novos conhecimentos. 


\section{RESUMO}

HAWTHORNE, AC. Avaliação comparativa entre enxertos alógenos e autógenos “onlay”. Estudo histológico, imunohistoquímico e tomográfico em coelhos. Ribeirão Preto, 2010. 99p. Dissertação [Mestrado] - Faculdade de Odontologia de Ribeirão Preto, Universidade de São Paulo.

A reconstrução dos maxilares em implantodontia através de métodos de enxertia óssea constitui o procedimento cirúrgico mais utilizado frente à perda fisiológica ou traumática a que estes ossos estão sujeitos. Os enxertos autógenos mostram vantagens em relação às demais técnicas de reconstrução no que se refere ao potencial regenerador ósseo, entretanto, a sua remoção implica obrigatoriamente na necessidade de áreas doadoras. Nas últimas décadas tem ocorrido um grande interesse pelos enxertos alógenos de banco de tecidos músculoesquelético (BTME) como alternativa às enxertias autógenas, como forma de evitar morbidade do sítio doador e redução de tempo e custos da cirurgia. O propósito do estudo foi comparar o comportamento dos enxertos alógenos com autógenos avaliados por métodos imunohistoquímicos, histológicos e tomográficos. Trinta e seis coelhos da linhagem New Zealand White foram submetidos a cirurgias para enxertia "onlay" de osso autógeno (grupo controle) e osso alógeno em lados diferentes da mandíbula de forma aleatória. Seis animais de cada grupo foram sacrificados aos 03, 05, 07, 10, 20 e 60 dias após as cirurgias. Cortes histológicos foram corados com Tricrômio de Mallory para as análises histológicas. As imuno marcações foram realizadas com osteoprotegerina $(\mathrm{OPG})$; receptor activator of nuclear factor$\mathrm{k} \beta$ ligand (RANKL); fosfatase alcalina (ALP); osteopontina (OPN); vascular endothelial growth factor (VEGF); tartrate-resistant acid phosphatase (TRAP); colágeno tipo I (Col I) e osteocalcina (OC). A manutenção do volume e densidade dos enxertos foi avaliada por meio de tomografias obtidas após as cirurgias e após os sacrifícios. Os enxertos autógenos e alógenos exibiram padrões de preservação de volume e densidade similares; os dados histológicos mostram que a remodelação óssea no grupo alógeno ocorreu de modo mais intenso que no grupo autógeno; a avaliação por microscopia de luz mostra que a incorporação do osso autógeno ao leito receptor foi mais eficiente que no grupo alógeno; no grupo alógeno os resultados de imunohistoquímica demonstraram um quadro típico de intensa remodelação dos enxertos.

Palavras-chave: Enxerto Ósseo “Onlay”, Enxerto Ósseo Alógeno, Enxerto Ósseo Autógeno, Avaliação Tomográfica, Avaliação imunohistoquímica, Avaliação Histológica. 


\begin{abstract}
HAWTHORNE, AC. Comparative evaluation about onlay allograt and autogenous graft. Histological, Immunohistochemical and tomographic study in the rabbits. Ribeirão Preto, 2010. 99p. Dissertação [Mestrado] - Faculdade de Odontologia de Ribeirão Preto, Universidade de São Paulo.

The reconstruction of jaws in implantology using methods of bone grafting constitutes is becoming the most popular surgical procedure due to the physiologic bone loss that follows teeth extraction or trauma. The autogenous grafts show advantages in relation to the other reconstruction techniques because its potential as bone regenerator. However, its removal implicates obligatorily in the areas donor areas. In the last decades aroused the interest for the bone bank (BTME) as alternative to the autogenous grafting, as a manner to avoid donor sites morbidity and reduction of time and surgery costs. The purpose of the study was to compare the behavior of allografts with autogenous using methods of immunochemistry, histology and tomography. Thirty six rabbits of the lineage New Zealand White were submitted to surgeries for onlay grafting of autogenous bone (group control) and allogenous bone randomly placed bilaterally in the mandible. Six animals of each group were sacrificed to the $03,05,07,10,20$ and 60 days after the surgeries. Paraffin sections were stained with Mallory's Trichrome for histologics analyses. Immuno labeling accomplished with osteoprotegerin (OPG); receptor activator of nuclear factor-k ligand (RANKL); alkaline fosfatase (ALP); osteopontin (OPN); vascular endothelial growth factor (VEGF); tartrate-resistant acid phosphatase (TRAP); collagen type I (COL I) and osteocalcin (OC). The maintenance of the volume and density of the grafts was evaluated on tomographs obtained after surgeries and sacrifices. The autogenous grafts and allografts exhibited patterns of volume preservation and similar density; the histological data show that the remodelation bone in the group allograft happened in a more intense way than in the autogenous group; the evaluation for light microscopic shows that the incorporation of the autogenous bone on donor's bed was more efficient than in the allogenous group; in the allogenous group for immunohistochemical results demonstrated a typical picture of intense remodelation of the grafts.
\end{abstract}

Key Words: Onlay Bone Graft, Alogeneic Bone Graft, Autogeneous Bone Graft, Tomographic evalution, Immunohistochemistry, Histologic evaluation. 


\section{LISTA DE FIGURAS}

Figura 01 - Coelho mantido em gaiolas individuais com água e comida à vontade em sala climatizada a $25^{\circ} \mathrm{C}$

Figura 02 - Anestesia geral por via intramuscular profunda no músculo reto femoral do membro posterior esquerdo com xilazina ${ }^{\circledR}$ misturada a quetamina ${ }^{\circledR}$

Figura 03 - Anestesia infiltrativa com mepivacaína 2\% com noradrenalina 1:200.000 em região de calota craniana

Figura 04 - Anestesia infiltrativa com mepivacaína 2\% com noradrenalina 1:200.000 em região submandibular

Figura 05 - Antibioticoterapia com oxitetraciclina por via intra peritonial........................... 34

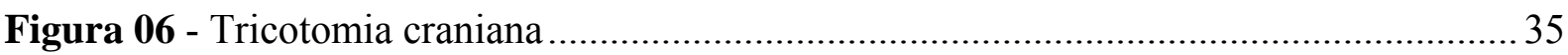

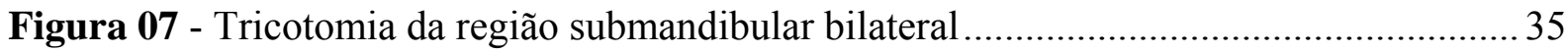

Figura 08 - Exemplo de enxerto ósseo de calota craniana de coelho e guia cirúrgico............ 36

Figura 09 - Incisão linear, diretamente sobre a pele, foi realizada ao longo da calota

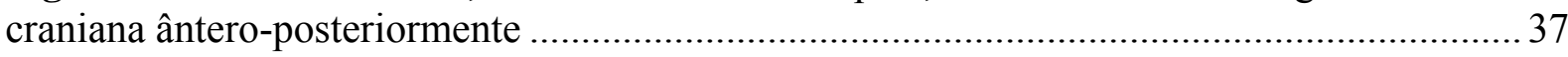

Figura 10 - Descolamento total do retalho e exposição da cortical da calota craniana............ 38

Figura 11 - Adaptação do guia cirúrgico em calota craniana ............................................... 38

Figura 12 - Demarcação com broca diamantada esférica em calota craniana. Nesse momento o guia cirúrgico foi removido para que as demarcações fossem aprofundadas ........39

Figura 13 - União das demarcações realizadas com broca tronco-cônica em calota craniana

Figura 14 - Aspecto do local da remoção do enxerto visualizando a integridade da dura máter.

Figura 15 - Sutura de periósteo, fáscia e gálea aponeurótica de calota craniana com Vicryl

4.0

Figura 16 - Sutura de pele de calota craniana com Nylon 4.0 ........................................... 40

Figura 17 - Remoção de espículas e pontas ósseas com broca tipo maxcut........................... 41

Figura 18 - Embalagem com fragmento ósseo enviado para UNIOSS ................................ 42

Figura 19 - Incisão linear em pele, em região mandibular ................................................. 43 
Figura 20 - Descolamento total do retalho e exposição da cortical mandibular. Notar (seta) o nervo mentual localizado ao lado esquerdo da figura

Figura 21 - Adaptação do guia cirúrgico em corpo mandibular para confecção das perfurações

Figura 22 - Perfurações realizadas sob irrigação abundante com soro fisiológico $0,9 \%$ de forma padronizada com a utilização do guia cirúrgico.

Figura 23 - Osso autógeno enxertado e fixado com parafuso 1,5 x 8,0 $\mathrm{mm}$ em um lado da mandíbula

Figura 24 - Osso alógeno enxertado e fixado com parafuso 1,5 x 8,0 $\mathrm{mm}$ em outro lado da mandíbula

Figura 25 - Sutura por planos (periósteo e músculos) com Vicryl 4.0 em região mandibular.

Figura 26 - Sutura bilateral da pele de região mandibular com Nylon 4.0 .....

Figura 27 - Corte histológico corado em Tricrômio de Mallory. Nesta fotomicrografia podemos observar o enxerto ósseo (EO) posicionado no leito receptor (LR) com presença de duas perfurações. $\mathrm{PF}=$ perfurações. $(5 \mathrm{x})$

Figura 28 - Marcação inumohistoquímica para proteína OPN - Enxerto autógeno (100x) .... 48

Figura 29 - Tomografia computadorizada em corte coronal.

Figura 30 - Corte tomográfico no plano coronal com mensuração de volume pelo software Dicom Works 1.3.5b

Figura 31 - Marcações das densidades em posição superior e inferior ao parafuso. Cada posição possui uma densidade média, sendo que a densidade do corte foi a média das densidades.

Figura 32 e 33 - Fotomicrografia de um sítio com enxerto autógeno (lado esquerdo) e alógeno (lado direito). Em ambos os enxertos observamos a presença do periósteo, porém com as fibras mais organizadas e evidentes no grupo autógeno. (16x). Tricrômio de Mallory

Figura 34 e 35 - Fotomicrografia de um sítio com enxerto autógeno (lado esquerdo) e alógeno (lado direito). Em ambos enxertos observamos a integridade do periósteo. As fibras estão mais organizadas. Há pouca diferença entres ambos os grupos. (16x). Tricrômio de Mallory

Figura 36 e 37 - Fotomicrografia de um sítio com enxerto autógeno (lado esquerdo) e alógeno (lado direito). Presença de formação óssea abaixo do periósteo mais intensa no grupo autógeno. Principal diferença entre os dois grupos no período experimental de 07 dias. (16x). Tricrômio de Mallory 
Figura 38 e 39 - Fotomicrografia de um sítio com enxerto autógeno (lado esquerdo) e alógeno (lado direito). Observamos em ambos os grupos a formação óssea abaixo do periósteo alcançado a interface enxerto e leito receptor. Observar no enxerto autógeno que há formação óssea na região cortical ao enxerto. (16x). Tricrômio de Mallory.

Figura 40 e 41 - Fotomicrografia de um sítio com enxerto autógeno (lado esquerdo) e alógeno (lado direito). No tempo de 20 dias, podemos observar que há uma formação óssea, integrada com a formação óssea da interface. No grupo autógeno a neoformação óssea envolve grande parte do enxerto ósseo, enquanto que no grupo alógeno esse envolvimento é menos intenso. (16x). Tricrômio de Mallory.

Figura 42 e 43 - Fotomicrografia de um sítio com enxerto autógeno (lado esquerdo) e alógeno (lado direito). Em ambos os grupos encontramos um osso maduro, no entanto em uma quantidade maior no grupo autógeno. (16x). Tricrômio de Mallory

Figura 44 - Fotomicrografia de um sítio com enxerto autógeno. Presença de infiltrado celular (IC) na interface (It) entre enxerto ósseo (EO) e leito receptor (LR) e na perfuração (Pf). Notar (seta) presença de canal de Harvers no enxerto ósseo. * = separação artefatual. (100x). Tricrômio de Mallory.

Figura 45 - Fotomicrografia de um sítio com enxerto autógeno. Redução do infiltrado celular (IC), com formação de redes de fibras colágenas (RFC), com início da proliferação celular (seta). $\mathrm{EO}=$ Enxerto ósseo. $\mathrm{LR}=$ Leito receptor. $\mathrm{It}=$ Interface. ${ }^{*}=$ separação artefatual. (100x). Tricrômio de Mallory

Figura 46 - Fotomicrografia de um sítio com enxerto autógeno. Deposição de osso novo imaturo (seta) em uma matriz extracelular de fibras colágenas frouxamente organizadas (RFC). Presença de tecido adiposo (TA) no interior do enxerto ósseo (EO). * = separação artefatual. (100x). Tricrômio de Mallory

Figura 47 - Fotomicrografia de um sítio com enxerto autógeno.Neoformação de osso imaturo (OI) por quase toda interface (It) entre enxerto ósseo (EO) e leito receptor (LR). Deposição de novo osso imaturo (seta), em uma matriz extracelular de fibras colágenas, localizado próximo a uma área de perfuração (Pf). (100x). Tricrômio de Mallory .....

Figura 48 - Fotomicrografia de um sítio com enxerto autógeno. Processo de incorporação do enxerto ósseo (EO) ao leito receptor (LR) bem evidente, caracterizado por pontes de osso maduro $(\mathrm{OM})$ e organizado com lamelas osteônicas unindo essas duas estruturas (seta). Observa-se ainda, presença de matriz extracelular de fibras colágenas (RFC) em perfuração (Pf). (100x) Tricrômio de mallory.

Figura 49 - Fotomicrografia de um sítio com enxerto autógeno. Intensa incorporação do enxerto ósseo (EO) ao leito receptor (LR). Observa-se uma linha divisória entre a intensa incorporação (setas). TC $=$ Tecido conjuntivo. (100x). Tricrômio de Mallory.

Figura 50 - Fotomicrografia dee um sítio com enxerto alógeno. Presença de infiltrado celular (IC) na interface (It) entre o enxerto ósseo (EO) e leito receptor (LR). Notar (seta) presença de lacuna de osteócito vazia. Principal diferença entre o enxerto autógeno. (100x). Tricrômio de Mallory..... 
Figura 51 - Fotomicrografia de um sítio com enxerto alógeno. Fornação de redes de fibras colágenas frouxamente organizadas (RFC) entre a interface (It) enxerto ósseo (EO) e leito recptor (LR). Pouca presença de infiltrado celular (IC). Pf = Perfuração. (100x). Tricrômio de Mallory

Figura 52 - Fotomicrografia de um sítio com enxerto alógeno. Redução significativa do infiltrado celular (IC) com organização das redes de fibras colágenas (RFC) na interface (It). EO = Enxerto ósseo. LR = Leito receptor. Pf = Perfuração. (100x). Tricrômio de Mallory

Figura 53 - Fotomicrografia de um sítio com enxerto alógeno. Presença de osso novo imaturo (OI) desorganizado, dividindo espaço com as redes de fibras colágenas frouxamente organizadas (RFC), em áreas da interface (It) e perfuração (Pf). Notar (seta) lacunas de Howship. EO = Enxerto ósseo. $\mathrm{LR}=$ Leito receptor. (100x). Tricrômio de Mallory

Figura 54 - Fotomicrografia de um sítio com enxerto alógeno. Neoformação de osso imaturo (OI) bem evidente unindo o enxerto ósseo (EO) ao leito receptor (LR). Notar (seta) formação de lamelas concêntricas. It $=$ Interface. $\mathrm{Pf}=$ Perfuração. (50x). Tricrômio de Mallory

Figura 55 - Fotomicrografia de um sítio com enxerto alógeno. Incorporação do enxerto ósseo (EO) ao leito receptor (LR), caracterizado por pontes de osso maduro (OM). Na margem lateral inferior do enxerto, pode se observar a intensa formação de tecido ósseo maduro, decorrente da reação do periósteo (RP). TC $=$ Tecido conjuntivo. (50x). Tricrômio de Mallory 


\section{LISTA DE GRÁFICOS}

Gráfico 01 - Média dos escores das proteínas ALP, TRAP, RANKL, OPN, OPG, OC e COL I no seis tempos de avaliação, para os grupos Autógeno e Alógeno.

Gráfico 02 - Gráfico da média do volume dos grupos estudados, cirurgia e sacrifício, nos 6 tempos experimentais

Gráfico 03 - Gráfico da variação do volume (depois - antes) para cada um dos grupos estudados, nos seis tempos de avaliação

Gráfico 04 - Média da densidade dos grupos estudados, cirurgia e sacrifício, nos seis tempos de avaliação.

Gráfico 05 - Gráfico da variação da densidade (cirurgia - sacrifício) para cada um dos grupos estudados, nos seis tempos de avaliação 


\section{LISTA DE TABELAS}

Tabela 01 - Escores da proteína ALP na comparação entre os grupos e tempos......................76

Tabela 02 - Escores da proteína TRAP na comparação entre os grupos e tempos.....................76

Tabela 03 - Escores da proteína RANKL na comparação entre os grupos tempos..................77

Tabela 04 - Escores da proteína OPN na comparação entre os grupos e tempos.......................77

Tabela 05 - Escores da proteína OPG na comparação entre os grupos e tempos......................78

Tabela 06 - Escores da proteína OC na comparação entre os grupos e tempos ........................ 78

Tabela 07 - Escores da proteína COL I na comparação entre os grupos e tempos....................79

Tabela 08 - Média e desvio padrão do volume $\left(\mathrm{mm}^{3}\right)$ e resultado da comparação entre os

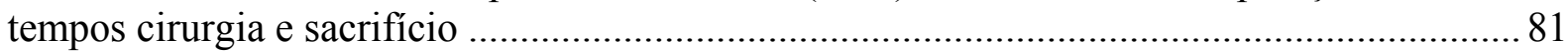

Tabela 09 - Média e desvio padrão da diferença (cirurgia - sacrifício) de volume (mm3) e resultados da comparação entre os grupos e os tempos de avaliação.

Tabela 10 - Média e desvio padrão da densidade (HU) e resultado da comparação entre o tempo da cirurgia e sacrifício

Tabela 11 - Média e desvio padrão da diferença (cirurgia - sacrifício) de densidade (HU) e resultado da comparação entre os grupos e os tempos de avaliação 


\section{LISTA DE ABREVIATURA}

\begin{tabular}{|c|c|}
\hline EDTA - & Ácido etileno-amino tetrácido \\
\hline PBS - & Phosphate buffered saline (Tampão fosfato) \\
\hline TRAP - & $\begin{array}{l}\text { Tartrate-Resistant Acid Phosphatase (Enzima lisossomal fosfatase ácida } \\
\text { resistente) }\end{array}$ \\
\hline OC - & Osteocalcina \\
\hline OPN - & Osteopontina \\
\hline OPG - & Osteoprotegerina \\
\hline RANKL - & $\begin{array}{l}\text { Receptor Activator of Nuclear Factor- } \mathrm{k} \beta \text { Ligand ( Ligante para receptor } \\
\text { ativador do fator nuclear- } \mathrm{k} \beta \text { ) }\end{array}$ \\
\hline ALP - & Fostase Alcalina \\
\hline COL I - & Colágeno Tipo I \\
\hline VEGF - & $\begin{array}{l}\text { Vascular Endotelial Grouth Factor (Fator de crescimento vascular } \\
\text { Endotelial) }\end{array}$ \\
\hline IgG - & Imunoglobulina $\mathrm{G}$ \\
\hline FORP-USP - & Faculdade de Odontologia de Ribeirão Preto - Universidade de São Paulo \\
\hline FAPESP - & Fundação de Amparo à Pesquisa do Estado de São Paulo \\
\hline $\mathbf{R P}-$ & Ribeirão Preto \\
\hline BTME - & Banco de Tecido Músculo-Esquelético \\
\hline SNT - & Sistema Nacional de Transplante \\
\hline DAB - & 3,3'-Diaminobenzidina-tetrahidrocloridrato \\
\hline FDBA - & Freeze-d ried bone allograft \\
\hline DFDBA - & Demineralized freeze-dried bone allograft \\
\hline
\end{tabular}




\section{LISTA DE SÍMBOLOS}

TM - Trade Mark

p - Nível de significância

mg - Miligrama

g- Grama

Kg - Quilograma

ml - Mililitro

mm - Milímetro

$\mathbf{m m}^{2}$ - Milímetro quadrado

$\mathbf{m m}^{3}$ - Milímetro cúbico

cm - Centímetro

pH - Potencial hidrogeniônico

KV - Quilovoltagem

mA - Miliamper

C - Celsius

\% - Porcentagem

HU - Hounsfield

h - Hora 


\section{SUMÁRIO}

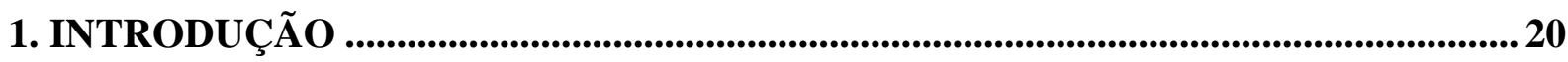

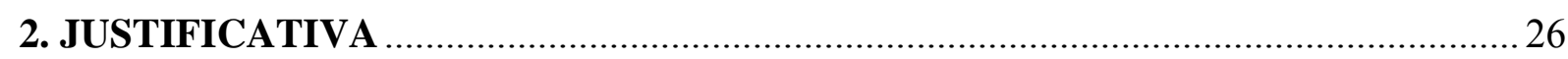

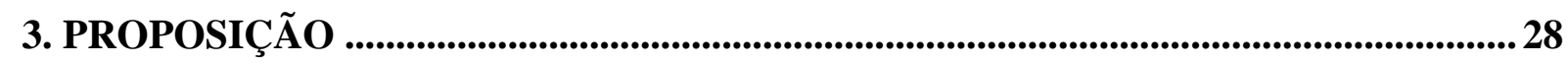

4. MATERIAIS E MÉTODOS.....................................................................................30

4.1 Aspectos éticos da pesquisa e apoio financeiro …………...............................................

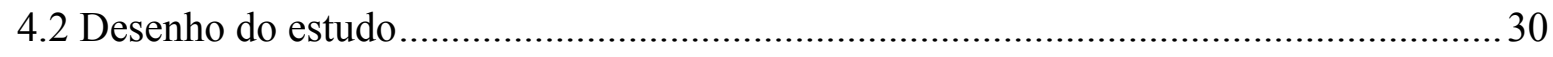

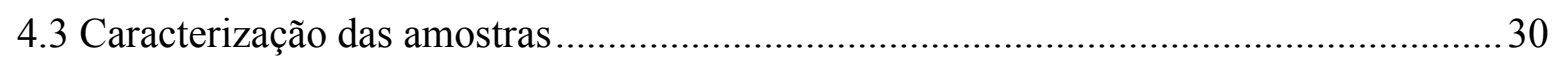

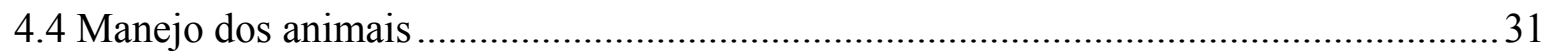

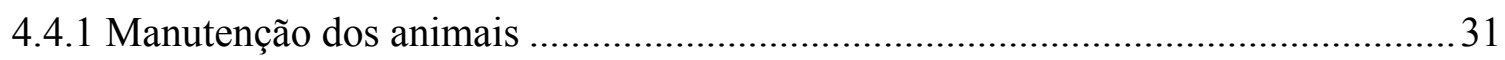

4.4.2 Protocolo de anestesia e medicação dos animais......................................................32

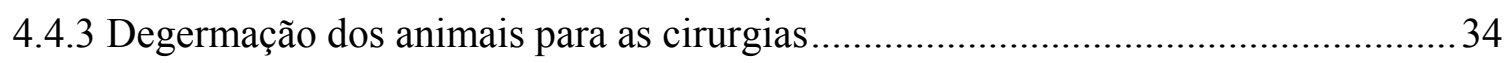

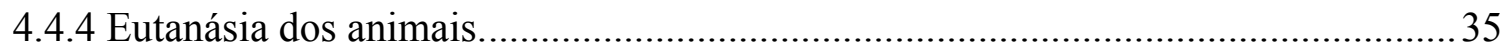

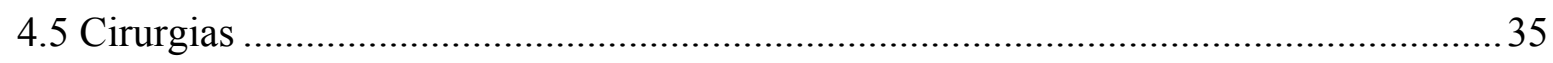

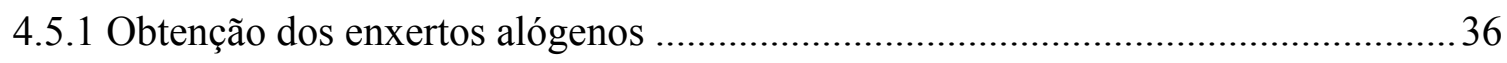

4.5.2 Obtenção dos enxertos autógenos .......................................................................4 42

4.5.3 Preparo do leito receptor e fixação dos enxertos ósseos alógenos e autógenos .......43

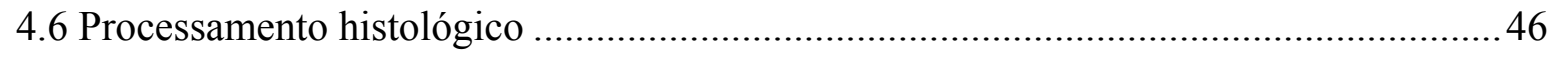

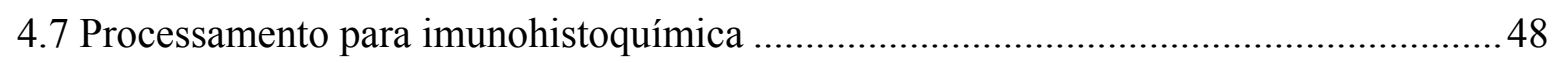

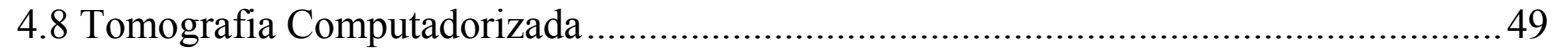

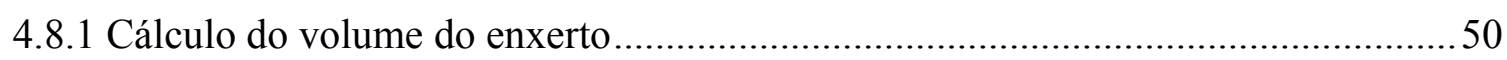

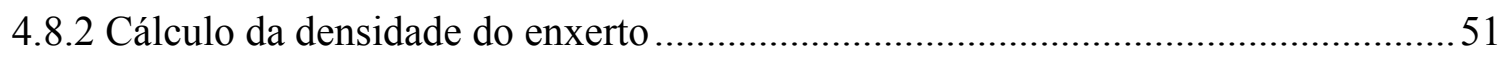

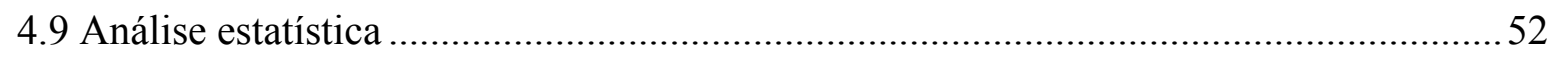

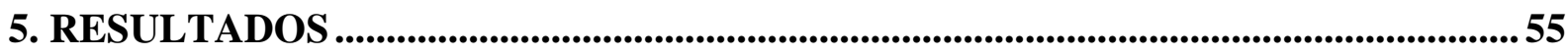

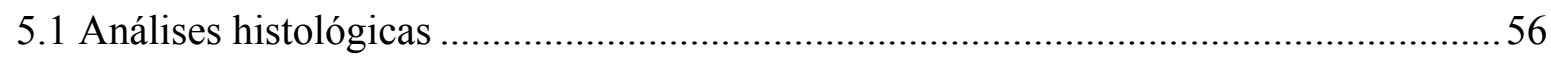

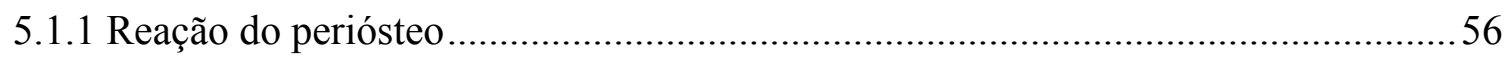

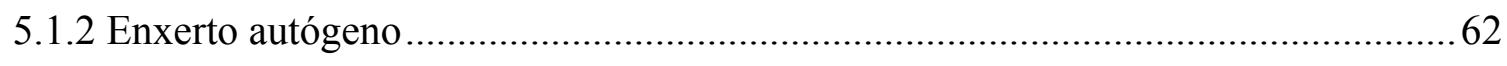

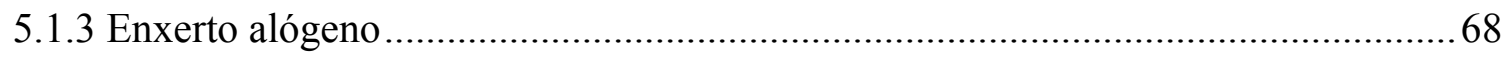

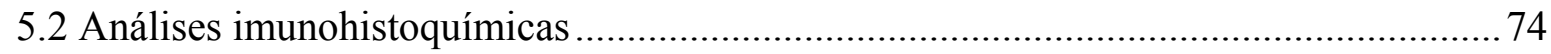

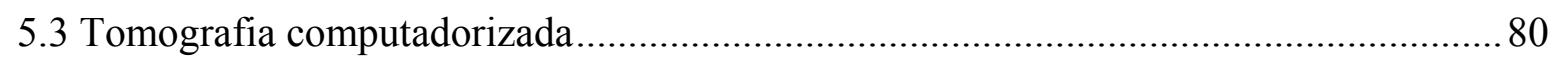

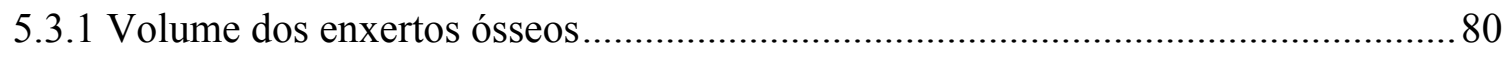

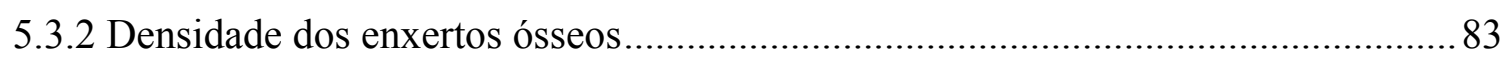

6. DISCUSSÃO …........................................................................................................................... 8

7. CONCLUSÃO.........................................................................................................................91

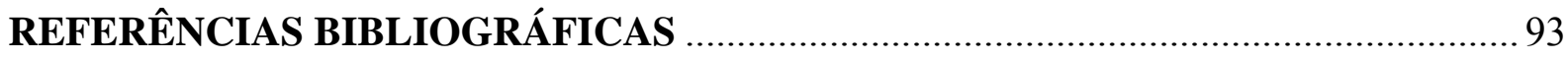




\section{INTRODUÇÃO}

Os implantes de titânio utilizados para reabilitação de espaços edêntulos nos maxilares propiciaram que a Odontologia fosse introduzida em um dos mais importantes paradigmas de sua história (MONOV et al, 2005). O ganho biológico e estético alcançado com essa opção terapêutica permitiu que áreas desdentadas pudessem ser mais eficazmente reabilitadas (AJZEN et al, 2005). Pequenas áreas que exigiam prótese dento suportada passaram a ser mais bem restauradas apoiadas exclusivamente em implantes de titânio, eliminando assim o desconforto de desgaste de dente ou usar uma prótese suportada por grampo metálico (OYAMA et al, 2004).

Com o aperfeiçoamento da técnica, a exigência estética aumentou consideravelmente e, assim estabeleceu o conceito de que o implante osseointegrável deveria ser instalado na posição mais aproximada à posição original do dente (PELEG et al, 2004; ANITUA et al; 2006). Os implantes não mais poderiam ser colocados de acordo com a conveniência do leito receptor, mas de modo que a prótese final mimetizasse fidedignamente o dente natural (PELEG et al, 2004; YAMADA et al, 2004; AJZEN et al, 2005). Além de preencher requisitos estéticos, o conjunto implante e prótese resgatariam em sua plenitude a biodinâmica da região (OHYA et al, 2005; BARONE et al, 2009).

Portanto, a posição ideal do implante ao tamanho e forma do osso remanescente é, muitas vezes, necessária ser estabelecida (KEITH et al, 2006). Com a exodontia o osso alveolar é absorvido diminuindo assim sua altura e largura (YAMADA et al, 2004; KLONGNOI et al, 2006a, 2006b; NISHIGUCHI et al, 2007). Assim, os enxertos ósseos se tornam indispensáveis na prática da implantodontia (OYAMA et al, 2004; MANNAI, 2006). A reconstrução dos maxilares pelo método de enxertia óssea constitui o procedimento cirúrgico mais utilizado frente à perda fisiológica ou traumática a que estes ossos estão sujeitos (MISH, 1997).

Dentre os enxertos ósseos, os autógenos mostram vantagens em relação às demais técnicas de reconstrução no que se refere ao potencial regenerador e é considerado padrão ouro por suas características de osteocondução que de acordo com Intini et al (2008) vem a ocorrer quando um material, freqüentemente inorgânico, permite aposição óssea sobre osso pré-existente, requerendo a presença de osso e células mesenquimais diferenciadas; osteoindução, em que todo material é capaz de induzir à transformação das células mesenquimais indiferenciadas em osteoblastos ou condroblastos, aumentando, assim, o 
crescimento ou podendo formar osso onde não é esperado (INTINI et al 2008) e osteogênese, que se refere ao material orgânico capaz de formação óssea diretamente a partir dos osteoblastos ( MISH \& DIETSCH, 1993), pois oferece um arcabouço tridimensional com células osteogênicas, sendo muito utilizado em cirurgias reconstrutivas nas áreas médicas e odontológicas (BOYNE, 1973; BOYNE, 1999; YOUNG et al, 1999; DOUGLAS, 2000; MONTAZEM et al. 2000; LEONETTI \& KOUP, 2003; PETRUNGARO \& AMAR, 2005; RAJAN et al, 2006). Entretanto, a sua remoção implica obrigatoriamente na necessidade de áreas doadoras, como enxertos intra-orais (MISH, 1997; ZEITER, 2000), crista do osso ilíaco (LAURIE et al,1984; FARIA et al, 2008) ou calota craniana (LIZUKA et al., 2004; PEDROSA JUNIOR et al, 2009), entre outros. Na atualidade, muito já se conhece a respeito ao processo de incorporação dos enxertos de blocos ósseos autógenos. Vários estudos sobre a importância da micro-arquitetura óssea, origem embrionária, orientação de aplicação ("inlay" ou "onlay"), presença do periósteo no enxerto, tratamento do leito receptor, taxa de revascularização e métodos de fixação do enxerto no leito receptor, parecem determinar o sucesso da técnica de enxertia (ALBERIUS et al, 1996; STEVENSON et al, 1996; ALBERIUS \& GORDH, 1998; OZAKI \& BUCHMAN, 1998; BUCHMAN \& OZAKI, 1999; TONG \& BUCHMAN, 2000; KHAN et al, 2005). Os grandes inconvenientes do emprego de osso autógeno estão relacionados à morbidade das áreas doadoras (LAURIE et al., 1984), necessidade um outro profissional para obtenção de osso de regiões como crista ilíaca e calota craniana, custos cirúrgicos (ELLIS III, 1993), maior tempo cirúrgico (SOHN et al, 2009), maior perda de sangue e em casos de grandes reconstruções, maior tempo de hospitalização (CONTAR et al, 2009), necessidade de convencer o paciente a submeter a um procedimento adicional caso o enxerto intra-oral não for suficiente (JOHNSON, 1980). Devido à isso, iniciou-se a busca por substitutos ósseos que evite os problemas na área doadora e que proporcione a reconstrução adequada e segura dos maxilares (ELLIS \& SINN III, 1993; PETRUNGARO et al. 2005). De acordo com Costa e Veinstein (1994) e Sohn et al (2009), os exemplos de substitutos ósseos (enxertos) podem ser classificados em: enxertos autógenos ou auto-enxertos: quando o tecido é transferido de uma posição para outra, de um mesmo indivíduo, não provocando, conseqüentemente, reação imune, podendo ser osso, cortical ou medular, quando é transplantado; enxertos alogênicos, homógenos ou homoenxertos: tecidos enxertados entre indivíduos da mesma espécie com genes não idênticos, como o osso fresco, congelado, liofilizado (FDBA), desmineralizado e liofilizado (DFDBA), xenoenxertos, heteroenxertos ou heterólogos: enxertos realizados entre indivíduos de espécies diferentes, sendo que, neste caso, se encontra o osso bovino e aloplástico: corpo estranho, inerte, 
utilizado para implantação nos tecidos, como fosfato de cálcio, hidroxiapatita, biocerâmica, além de outros tipos.

Nas últimas décadas tem aumentado o interesse pelos enxertos alógenos de banco de tecidos músculo-esquelético (BTME), para evitar os inconvenientes da enxertia autógena. Esse tipo de tecido ósseo tem a característica de ser originado da mesma espécie, porém de genótipo diferente (HOLMQUIST et al, 2007). Os enxertos ósseos alógenos têm sido utilizados desde 1880 como substitutos ósseos na área da ortopedia, principalmente na tentativa de reabilitar perdas por infecção ou por tumores (TOMFORD, 2000), na área odontológica têm sido utilizados como terapia regenerativa periodontal, sozinho ou em combinação com barreiras membranosas, para promover a restauração ou reconstituição de tecidos destruídos por doenças periodontais inflamatórias (REYNOLDS \& BOWERS, 1996), como substituto ósseo para enxertia em procedimento de sinus lifiting (CHAUSHU et al, 2009) e região posterior de mandíbula atrófica (NISSAN et al, 2009). A partir da década de 1980, com um maior uso desta modalidade de transplante, muitas questões têm sido levantadas, tais como a possibilidade de transmissão de doenças e legislação pertinente (KAPPE et al, 2009). Frente aos riscos de transmissão de doenças tais como a hepatite e o HIV (HOLMQUIST et al, 2007), muitos estudos têm investigado a segurança dos métodos de preparo e armazenamento desses tecidos (HYATT, 1950 e 1952; MARTHY \& RICHTER, 1998). Na história, apenas alguns casos de transmissão do HIV e hepatite C foram publicadas (SIMONDS, 1992;), mas a partir da década de 90 muita ênfase em relação ao preparo e armazenamento desses materiais foi dado pelos bancos de tecidos, o que fez com que nenhum caso fosse evidenciado na literatura e nos órgãos de saúde mundial nesta última década (TOMFORD 2000; AMERICAN ACADEMY OF PERIODONTOLOGY, 2001).

Existem várias técnicas de preparo do osso alógeno com a finalidade de reconstrução óssea. Os principais objetivos são a diminuição de sua antigenicidade e manutenção das características indutoras. (GARBIN JÚNIOR, 2008). Geralmente o tecido ósseo alógeno passa por processamento que consiste em uma série de "banhos" com medicamentos antibióticos e solventes, criodesinfecção em câmeras frias a $-80^{\circ} \mathrm{C}$ podendo ainda ser liofilizados, desmineralizados ou irradiados (SALAI et al., 2000; NGUYEN et al., 2006; HOLTZCLAW et al, 2008).

No Brasil existem seis Bancos de Tecidos Músculo-Esqueléticos (BTME) autorizados pelo Sistema Nacional de Transplantes (SNT) a colher, processar e distribuir os enxertos ósseos alógenos. O acesso para utilização destes tecidos por Cirurgiões Dentistas foi somente autorizado pelo Ministério da Saúde a partir de dezembro de 2005. O cadastramento de 
profissionais das especialidades de Cirurgia e Traumatologia Buco-Maxilo-Facial, Periodontia e Implantodontia pode ser realizado através do endereço eletrônico do Ministério da Saúde (www.saude.gov.br/transplantes) ou através das agências do Sistema Nacional de Transplante que se encontra em vários estados brasileiros.

A literatura mostra poucos trabalhos investigando a incorporação e manutenção de volume dos enxertos ósseos alógenos em bloco junto ao leito receptor. Shand et al, (2002) examinaram a resposta do enxerto ósseo alógeno colhido da região fronto-parietal da calota de 8 coelhos doadores, processado segundo o protocolo do Banco de Ossos de Victória (Austrália) e instalados em defeitos realizados na região parietal da calota de 15 coelhos receptores. Nesta pesquisa os autores utilizaram avaliações radiográficas, microscopia por fluorescência e histológica. Após um ano de acompanhamento os autores observaram que os enxertos ósseos alógenos tiveram boa qualidade de incorporação e processo de osteocondução, o qual revigora sua utilização no manejo de defeitos ósseos extensos. Na área médica e odontológica estudos clínicos têm demonstrado a utilização dos enxertos ósseos alógenos de bancos músculo-esqueléticos, com intuito de reabilitar perdas devido a traumas, tumores e deformidades congênitas, principalmente em casos de crianças onde a quantidade de osso doador é pequena (ELLIS \& SINN, 1993). Virolainen et al (2003) avaliaram à longo prazo o uso do enxerto alógeno fresco congelado, não observaram qualquer reação alérgica, rejeição ou anticorpo inesperado após transplante ósseo alógeno em um período de 30 anos. Aho et al (1998) através de avaliações histológicas e respostas imunológicas, não encontraram nenhum sinal de reação antigênica para o uso de enxerto alógeno fresco congelado no tratamento de grande defeitos ósseos. Entretanto, raros são os artigos encontrados na literatura científica que demonstram a aplicação de enxertos ósseos alógenos em blocos para aumento de volume dos rebordos atróficos com a finalidade de reabilitação com implantes (TORREZAN et al. 2003; LEONETI \& KOUP., 2003; PETRUNGARO et al., 2005).

O processo de ossificação e reparo de fraturas utilizando enxerto alógeno e autógeno são distintos. Quando foi utilizado o enxerto autógeno como tecido de reconstrução interfragmentária, o enxerto autógeno sofreu um reparo concomitante de ossificação do tipo endocondral e intramembranosa, com a presença de calo ósseo após 4 semanas. Já nos casos onde foi utilizado o enxerto alógeno, a ossificação foi apenas endocondral, com presença de cartilagem ao redor do enxerto e atraso do reparo ósseo (HIROMU ITO et al., 2005). Segundo os autores, este fato é devido a uma deficiência de fatores de crescimento nos enxertos alógenos que exibem papel importante na vascularização (Fator de Crescimento Vascular 
Endotelial - VEGF) e no processo de remodelação óssea (Ligante para receptor ativador do fator nuclear - RANKL).

O osso alógeno congelado foi recentemente introduzido como opção para reconstrução de áreas dos maxilares, candidatas a receberem implantes de titânio osseointegrável, devido à facilidade de aquisição em quantidade desejada junto ao BTME, fácil manipulação, redução do tempo cirúrgico e de anestesia (CONTAR et al, 2009), menor sangramento (TOMFORD \& MANKIN, 1999; GAMRADT \& LIEBERMAN, 2003) diminuição da morbidade pósoperatória por não necessitar de intervenção em região doadora (BARONE et al, 2009) e possibilidades de grandes reconstruções sob anestesia local. Apesar de o resultado ser bastante satisfatório na maioria dos casos, as enxertias aposicionadas nos maxilares autógenas ou alógenas - invariavelmente está sujeita a algum grau de absorção (CLAYMAN, 2006). Diante da larga utilização de enxertos aposicionados para melhorar a espessura ou altura do osso que receberá implantes de titânio e do grande aprimoramento técnico que tem sido observado nos seus protocolos cirúrgicos, artigos que estudem a biologia do processo de reparação desses enxertos e sua incorporação aos maxilares são escassos. Essa demanda de conhecimento científico é ainda maior em relação aos enxertos alógenos.

Conhecendo a escassa base científica sobre o processo de incorporação de enxertos ósseos alógenos em bloco, quando colocados de maneira aposicional "onlay" ao leito receptor, e dos processos de remodelação, revascularização e manutenção de volume, este trabalho visa contribuir com informações fundamentais sobre o comportamento entre o enxerto e o leito receptor. Com esse objetivo, há a necessidade de mapear os eventos biomoleculares nos quais os enxertos alógenos possam estar envolvidos na sua incorporação, tais como a avaliação da expressão de proteínas ósseas que caracterizam a deposição de matriz óssea (osteogênese), vascularização (angiogênese) e o processo de remodelação (osteoclastogênese), que somados as análises tomográficas e histológicas, possam contribuir na comparação com enxertia onlay com osso autógeno. 
2. JUSTIFICATIVA 


\section{JUSTIFICATIVA}

O estudo proposto representa a continuação de dois projetos em que foram utilizados metodologia científica similar para avaliar enxertos "onlay" de crista ilíaca - PARTE I, apresentado no Congresso Europeu de Osseointegração, Zurique-2006 e publicado em (Immunohistochemical, tomographic and histological study on onlay iliac grafts remodeling.) Clin Oral Implants Res. 2008 Apr;19(4):393-401. e para avaliar o comportamento biológico de enxertos de calota craniana em mandíbula de coelhos - PARTE II, publicado em (Immunohistochemical, tomographic and histological study on onlay bone graft remodeling. Part II: calvarial bone.) Clin Oral Implants Res. 2009 Apr; 20:1254-1264.

A realização do projeto em questão com osso alógeno além de esclarecer os objetivos propostos, permitirá futuramente à análise comparativa entre os três tipos de enxertos (crista ilíaca, calota craniana e osso alógeno), uma vez que está sendo utilizada a mesma metodologia com características multidisciplinares e executada pelo mesmo grupo de pesquisadores. 
3. PROPOSIÇÃO 


\section{PROPOSIÇÃO}

Os objetivos deste estudo são:

1) investigar as características histológicas de enxertos ósseos alógenos colhidos da calota de coelhos e processados pelo BTME da Universidade de Marília, a serem instalados "onlay" em mandíbula de coelhos;

2) relacionar, por meio de procedimentos imunoistoquímicos, os eventos biomoleculares que seguem a enxertia óssea (angiogênese, parâmetros de osteogênese e remodelação);

3) estabelecer, através de medidas tomográficas, a manutenção do volume e da densidade do enxerto ósseo no longo prazo. 


\section{MATERIAIS E MÉTODOS}

\subsection{Aspectos éticos da pesquisa e apoio financeiro}

O projeto desta pesquisa foi encaminhado para a Comissão de Ética no Uso de Animais da Universidade de São Paulo (USP) de Ribeirão Preto (RP). O parecer desta comissão foi favorável, considerando que os trabalhos desenvolvidos neste experimento não caracterizam abuso contra o bem-estar animal. Dessa forma, eles foram apreciados como eticamente corretos, conforme parecer protocolado e aprovado sob número 07.1.1488.53.6.

O projeto teve auxílio financeiro da Fundação de Amparo à Pesquisa do Estado de São Paulo (FAPESP), sob o processo número 2008/01382-6 e concessão de Bolsa de Mestrado sob o processo número 2008/51358-4.

\subsection{Desenho do estudo}

Fragmentos padronizados de osso removidos da calota craniana de coelhos foram processados em BTME e posteriormente aposicionados no corpo da mandíbula em um dos lados, enquanto os enxertos autógenos foram aposicionados em posição contralateral, após perfurações dos leitos receptores e fixados com parafusos de titânio 1,5 $\mathrm{mm}$ x 8,0 mm.

Objetivando conhecer as características de cada enxerto, alguns experimentos foram conduzidos para investigar: o comportamento histológico; os eventos biomoleculares ocorridos após a enxertia óssea, por meio de procedimentos imunohistoquímicos e a manutenção das dimensões volumétricas e de densidade de cada enxerto por meio de análises tomográficas.

\subsection{Caracterização das amostras}

Para este estudo foram utilizados cinqüenta e seis coelhos adultos, Oryctolagun cuniculus, da linhagem Nova Zelândia. Foram selecionados coelhos não isogênicos, machos, adultos, pesando 3,5 a 4,0 kg. Os animais, nascidos e criados no Biotério Central do Campus da USP de RP, eram clinicamente saudáveis e livres de ectoparasitas e endoparasitas, estando aptos a constituir a população desta pesquisa.

Esta pesquisa demandou 56 coelhos, sendo desta quantidade total, 20 coelhos utilizados como doadores ósseos, para obtenção dos enxertos alógenos e 36 coelhos utilizados como receptores dos enxertos ósseos. 
Esses 36 coelhos receberam dois tipos de enxertos ósseos. De um lado da mandíbula era enxertado de uma maneira aposicional (“onlay”) um bloco ósseo autógeno, denominado de Grupo I (grupo controle). Do outro lado mandibular, um bloco ósseo alógeno era enxertado, denominado Grupo II. A determinação de qual lado seria enxertado o bloco ósseo autógeno ou o bloco ósseo alógeno era realizada de forma aleatória.

\subsection{Manejo dos animais}

\subsubsection{Manutenção dos animais}

Durante todo o experimento (nos períodos pré e pós-operatórios), os animais foram mantidos em condições sanitárias convencionais no Biotério I da Faculdade de Odontologia de Ribeirão Preto (FORP) da USP. O acondicionamento foi realizado em gaiolas metálicas e individuais (Figura 1). Os coelhos recebiam cuidados veterinários e livre acesso à água e suporte nutricional em padrão de laboratório durante todo o período de experimentação. $\mathrm{O}$ ambiente era limpo e protegido de estímulos auditivos para evitar o estresse. O ambiente era climatizado através de ar condicionado, em temperatura estabilizada na faixa de $25^{\circ} \mathrm{C}$, a umidade relativa do ar na faixa entre 40 a $60 \%$ e os animais foram expostos à luminosidade artificial entre 08 e 10 horas por dia. Todos os cuidados com os animais foram realizados diariamente por dois bioteristas contratados pela FORP.

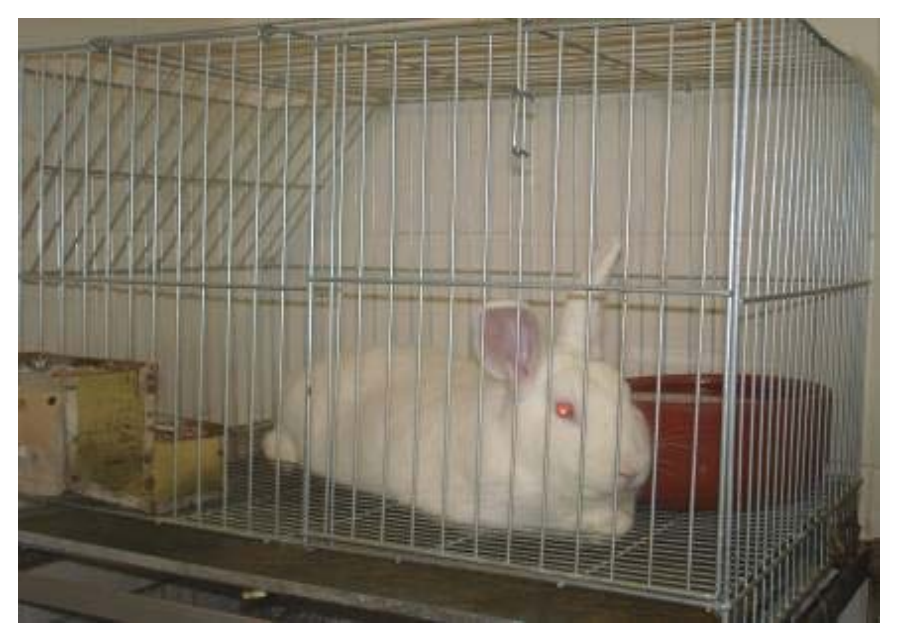

Figura 1 - Coelho mantido em gaiolas individuais com água e comida à vontade em sala climatizada a $25^{\circ} \mathrm{C}$. 


\subsubsection{Protocolo de anestesia e medicação dos animais}

Todos os procedimentos cirúrgicos foram conduzidos sob anestesia geral. Pelo protocolo selecionado, os coelhos foram submetidos a uma sedação com acepromazina ${ }^{\circledR}(2,0$ $\mathrm{mg} / \mathrm{ml}$ ) na dose de $1,0 \mathrm{mg} / \mathrm{kg}$ administrada por via subcutânea, 15 minutos antes da cirurgia. A seguir, por via intramuscular profunda, no músculo reto femoral do membro posterior esquerdo foi realizada a anestesia geral com xilazina ${ }^{\circledR}(20 \mathrm{mg} / \mathrm{ml}$ - Calier Laboratories, Barcelona, Spain) na dose de 3,0 mg/Kg misturada a quetamina $10 \%(50,0 \mathrm{mg} / \mathrm{ml}$ - União Química Farmacêutica Nacional S.A., Embuguaçú, São Paulo, Brasil) na dose de 60,0 mg/Kg (Figura 2). Este protocolo foi também utilizado por Faria et al (2008), Pedrosa Junior et al (2009) e Oliveira Neto et al (2010).

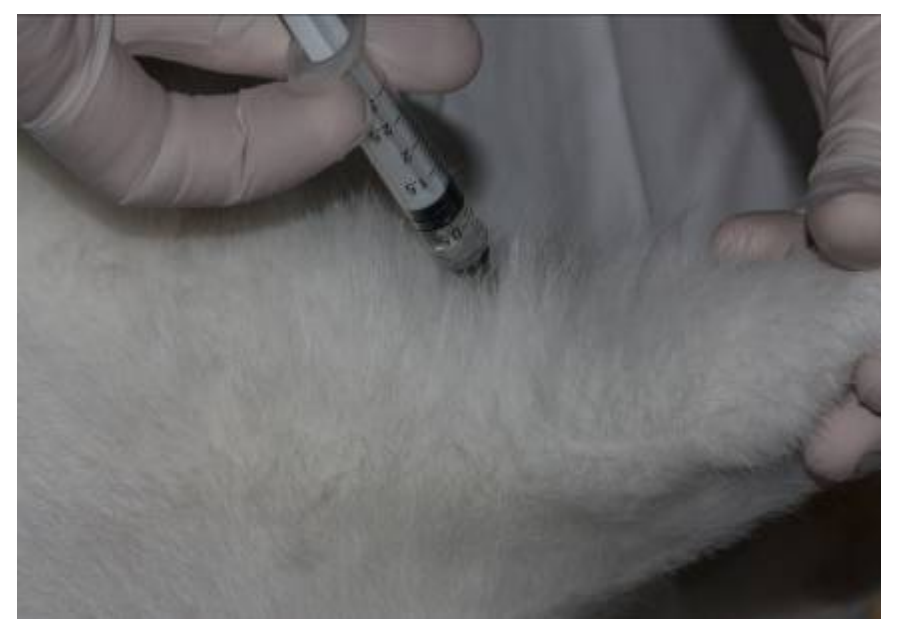

Figura 2 - Anestesia geral por via intramuscular profunda no músculo reto femoral do membro posterior esquerdo com xilazina ${ }^{\circledR}$ misturada a quetamina $10 \% \AA$.

No sentido de melhorar o manejo da hemostasia intra-operatória e da dor pósoperatória, os tecidos foram infiltrados com $0,9 \mathrm{ml}$ de mepivacaína $2 \%$ com noradrenalina 1:200.000 na região de calota craniana (Figura 3) e 1,2ml em cada lado da mandíbula (Figura 4), antes dos procedimentos cirúrgicos. 


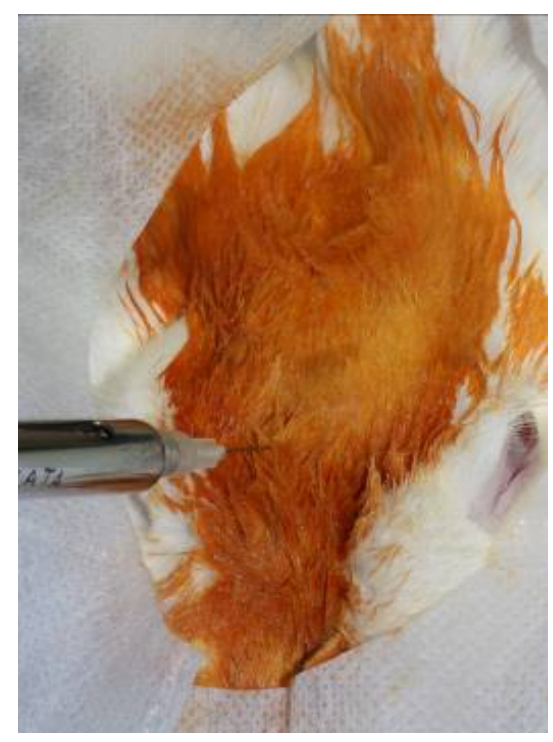

Figura 3 - Anestesia infiltrativa com mepivacaína 2\% com noradrenalina 1:200.000 em região de calota craniana.

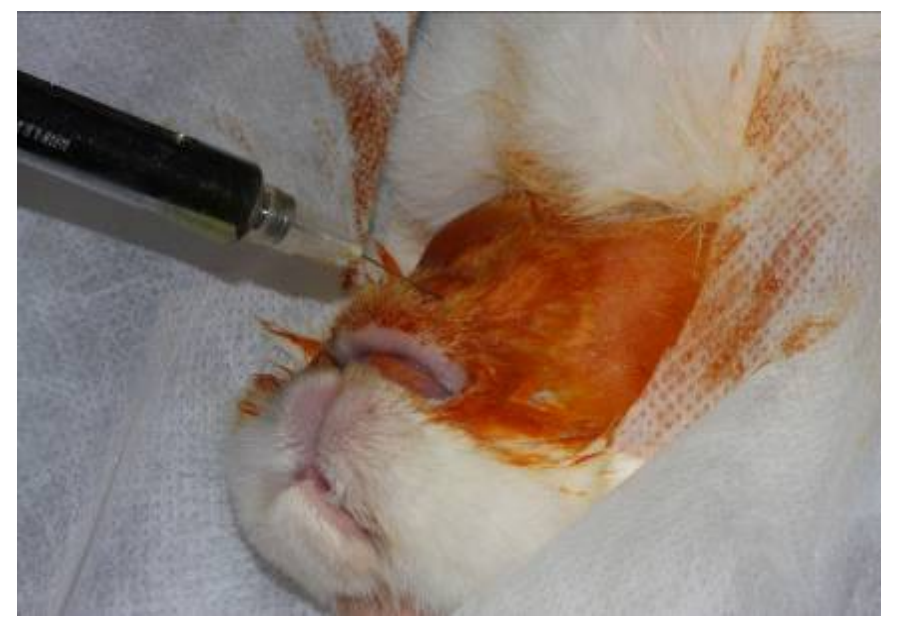

Figura 4 - Anestesia infiltrativa com mepivacaína 2\% com noradrenalina 1:200.000 em região submandibular. 
Seguindo o protocolo utilizado por Oliveira Neto et al (2010), após a anestesia os animais receberam antibioticoterapia profilática com oxitetraciclina $(1,0 \mathrm{~g} / 10 \mathrm{ml})$ na dose de $0,2 \mathrm{ml} / \mathrm{Kg}$ e nos 03 dias subseqüentes pela via intra-peritoneal (Figura 5). A analgesia foi assegurada pela administração de buprenorfina $(0,3 \mathrm{mg} / \mathrm{mL})$ na dose de $0,02 \mathrm{mg} / \mathrm{Kg}$ e antiinflamatório cetoprofeno (Profenid ${ }^{\circledR} 100 \mathrm{mg} / 2 \mathrm{ml}$ - Distribuidora Farmácia Brasil LTDA, Jandira SP) na dose de 3,0 mg/Kg, ambos por via intra-muscular.

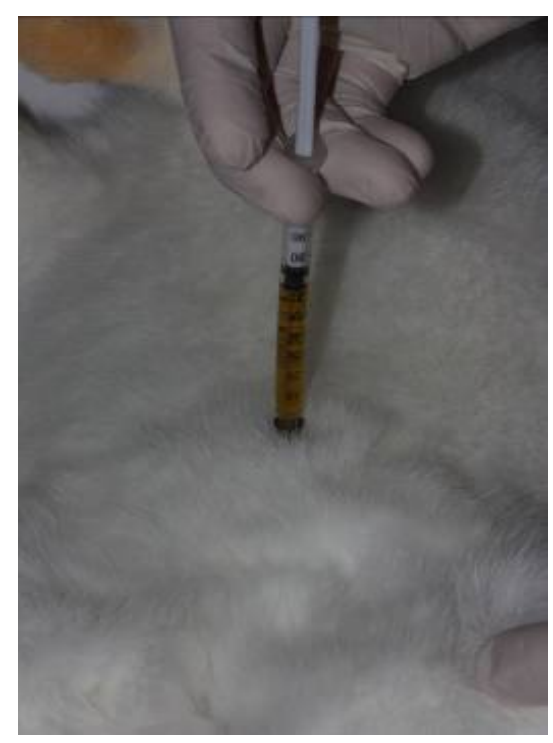

Figura 5 - Antibioticoterapia com oxitetraciclina por via intra-peritonial.

\subsubsection{Degermação dos animais para as cirurgias}

Depois de anestesiados, os animais foram tricotomizados em região craniana e região submandibular bilateral (Figuras 6 e 7). 


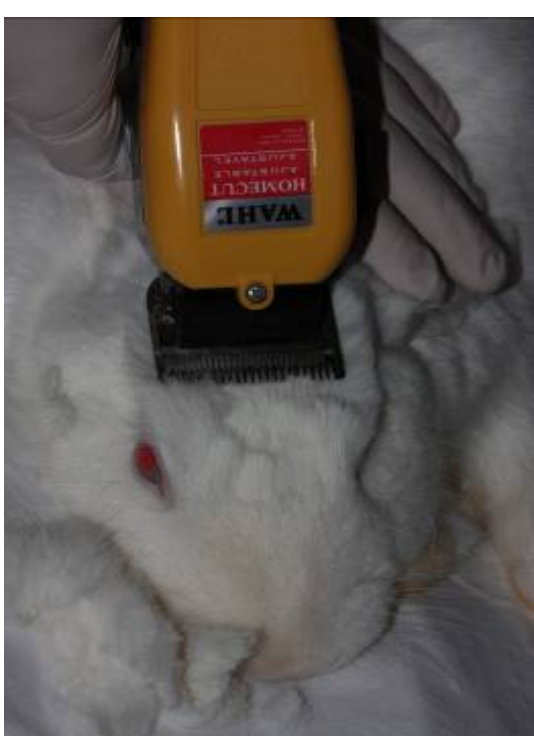

Figura 6 - Tricotomia craniana.

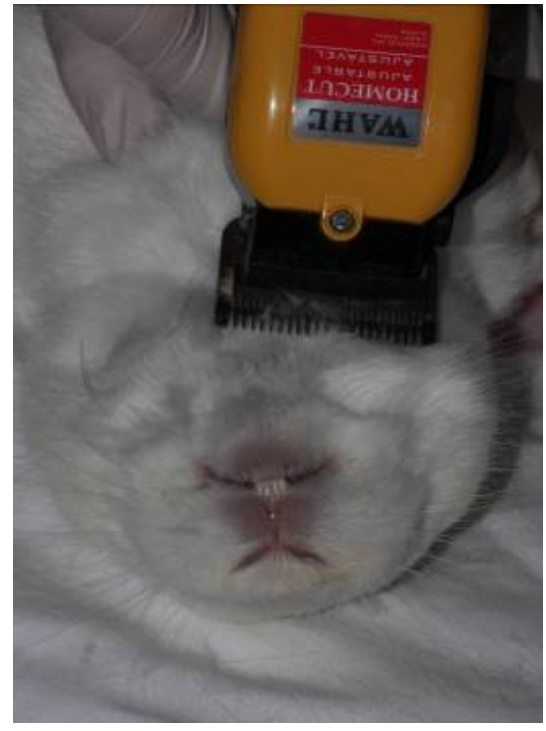

Figura 7 - Tricotomia da região submandibular bilateral.

A solução de iodo polivinilpirrolidona a $10 \%$ tópica foi o agente usado na degermação da pele. Após a degermação, campos cirúrgicos estéreis foram posicionados.

\subsubsection{Eutanásia dos animais.}

Seis coelhos de cada grupo foram sacrificados aos 03, 05, 07, 10, 20 e 60 dias após a cirurgia, através de administração excessiva de Tiopental 1,0 g (2,0 ml) por via endovenosa. A morte foi constatada pela falta de expansão torácica e batimentos cardíacos, midríase e ausência de reflexo palpebral.

Seguinte à eutanásia, os animais foram submetidos a novo exame tomográfico da mandíbula. Após as retiradas dos tecidos que seriam objeto de estudo, os animais foram contidos em sacos especiais, para posterior descarte, seguindo protocolos padrões de manuseio de material biológico que prevêem a sua incineração como lixo hospitalar.

\subsection{Cirurgias}

Todas as cirurgias foram realizadas dentro dos padrões assépticos e sempre pelo mesmo cirurgião. Todos os animais foram submetidos a cirurgias no crânio para obtenção dos enxertos autógenos e cirurgias bilaterais na mandíbula, especificamente na região de corpo 
mandibular, logo abaixo da região de pré-molares e molares e posteriormente aos ápices dos incisivos, para fixação dos blocos ósseos obtidos. Exceto 20 coelhos que foram submetidos apenas como doadores ósseos para os enxertos alógenos, sendo sacrificados logo após a remoção do enxerto. Dois blocos ósseos foram transplantados para a mandíbula, de um lado foi enxertado com osso autógeno (Grupo I - controle), do outro lado, foi realizado enxerto ósseo alógeno (Grupo II), sendo essa escolha de forma randômica. Ambos os lados foram padronizadamente perfurados.

Em nenhum momento o padrão alimentar dos animais esteve prejudicado, uma vez que as incisões para a mandíbula foram realizadas por via extra-bucal.

\subsubsection{Obtenção dos enxertos alógenos}

Os enxertos alógenos foram obtidos da calota craniana da região parietal de coelhos de forma padronizada através de guia cirúrgico, com medidas de $10,0 \mathrm{~mm}^{2}$, peça de mão e brocas sob irrigação de solução salina, para que todos os enxertos alógenos tivessem as mesmas medidas e processados de acordo com o protocolo do BTME da Universidade de Marília - UNIOSS e armazenados de forma padronizada (Figura 8).

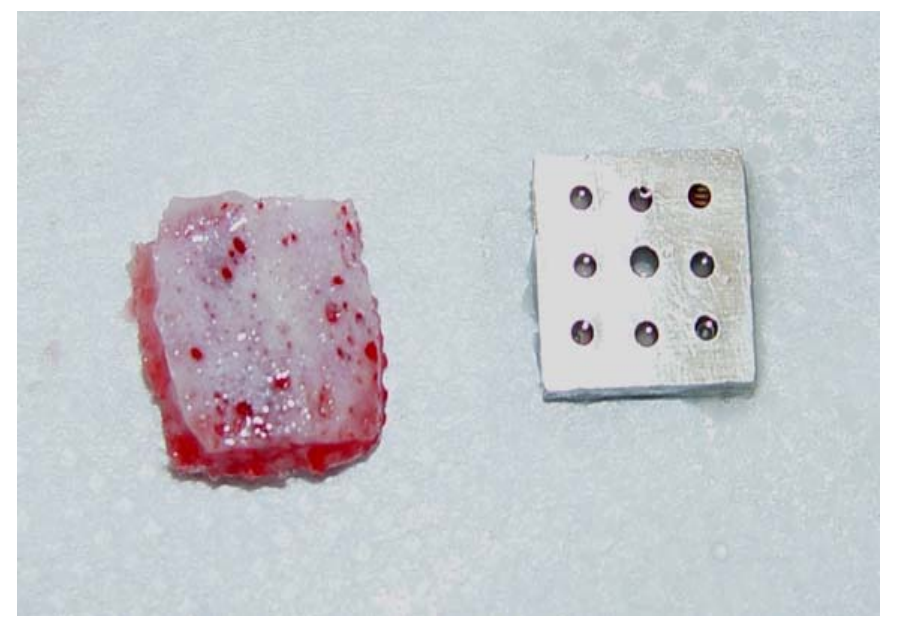

Figura 8 - Exemplo de enxerto ósseo de calota craniana de coelho e guia cirúrgico.

Cada coelho pôde doar duas amostras de osso da calota craniana. Isto foi previamente estudado anatomicamente em calotas secas de coelhos. Desta maneira, foram utilizados 20 
coelhos para o processamento alógeno, totalizando 40 blocos ósseos para o estudo (4 a mais, para caso ocorresse alguma intercorrência).

Com a sala cirúrgica limpa adequada para uma cirurgia de alto risco, o coelho sob efeitos da anestesia geral foi submetido à tricotomia craniana. A área recebeu aplicação tópica de solução de iodo polivinilpirrolidona a $10 \%$ e posteriormente, coberta com campos cirúrgicos, deixando exposto apenas a área a ser operada. A área em questão foi infiltrada com mepivacaína $2 \%$ e noradrenalina 1:200.000. Uma incisão linear, diretamente sobre a pele, medindo 5,0 cm, foi realizada ao longo da calota craniana ântero-posteriormente (Figura 9).

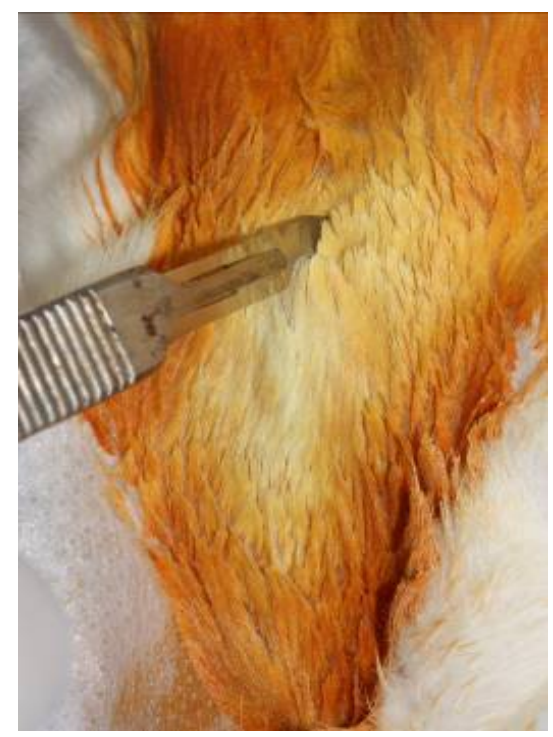

Figura 9 - Uma incisão linear, diretamente sobre a pele, foi realizada ao longo da calota craniana ântero-posteriormente.

A gálea aponeurótica e a fáscia foram incisadas e rebatidas, seguido de incisão periosteal para exposição da cortical da calota craniana (Figura 10). 


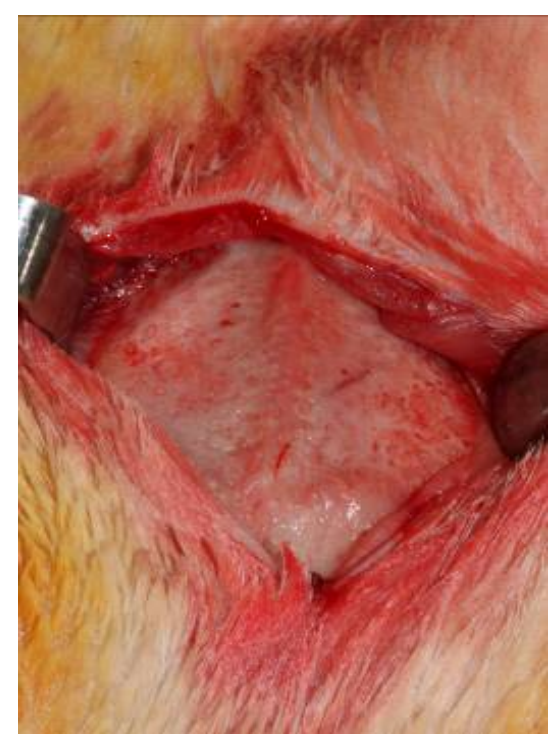

Figura 10 - Descolamento total do retalho e exposição da cortical da calota craniana.

Após o rebatimento e descolamento do tecido, o guia cirúrgico medindo 10 X $10 \mathrm{~mm}$ foi adaptado para padronização do tamanho dos enxertos (Figura 11).

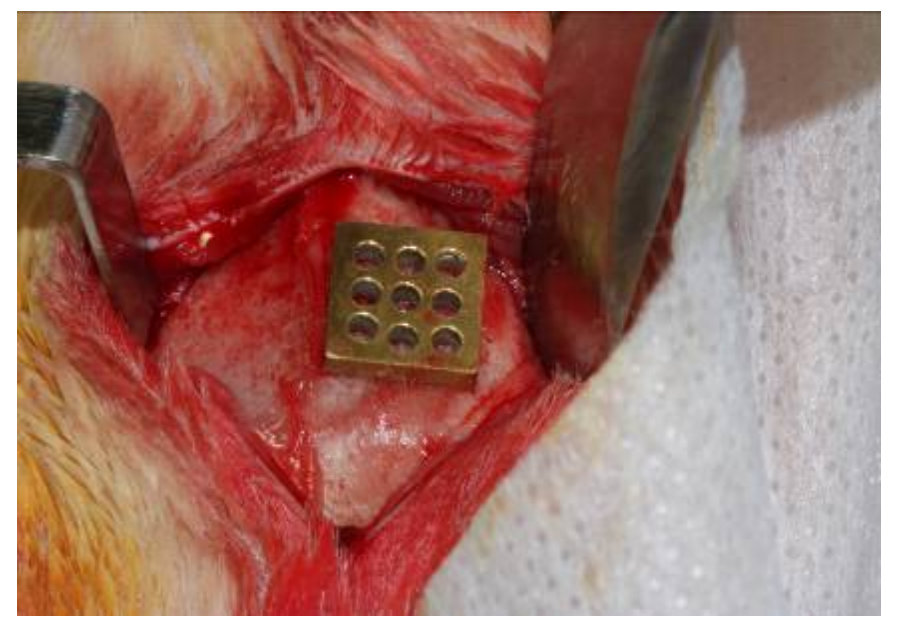

Figura 11 - Adaptação do guia cirúrgico em calota craniana.

O enxerto ósseo foi obtido utilizando brocas esféricas e tronco-cônicas, com auxílio de motor elétrico e peça de mão. As demarcações das dimensões do enxerto foram realizadas em conjunto com o guia cirúrgico, porém ao final das demarcações ao redor do guia, este era 
removido para que as demarcações fossem aprofundadas e depois unidas com uma broca tronco-cônica (Figuras 12 e 13).

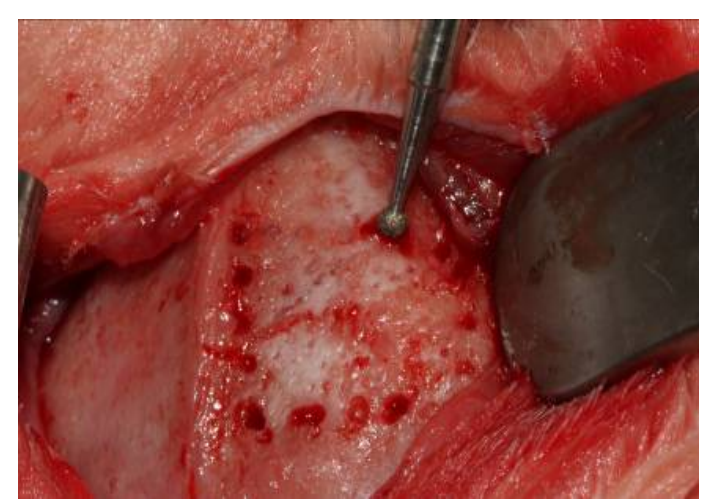

Figura 12 - Demarcação com broca diamantada esférica em calota craniana. Nesse momento o guia cirúrgico foi removido para que as demarcações fossem aprofundadas.

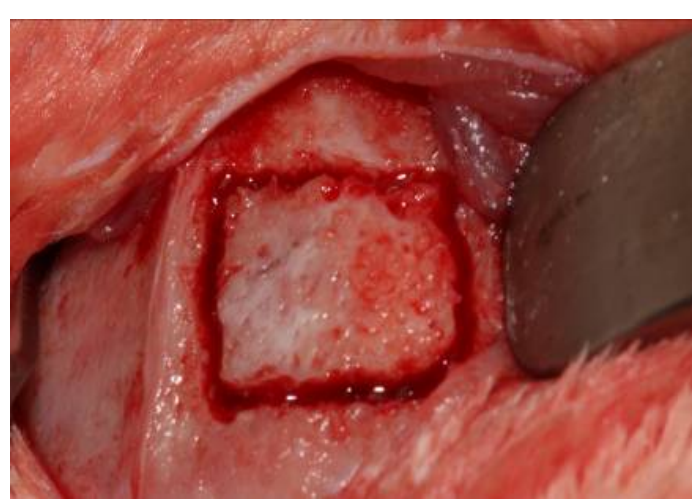

Figura 13 - União das demarcações realizada com broca tronco-cônica em calota craniana.

Os cortes foram realizados sob irrigação abundante de solução físiológica a $0,9 \%$ diretamente sobre a área ostectomizada. A remoção do enxerto foi realizada de forma cuidadosa para que não ocorresse laceração da dura máter (Figura 14).

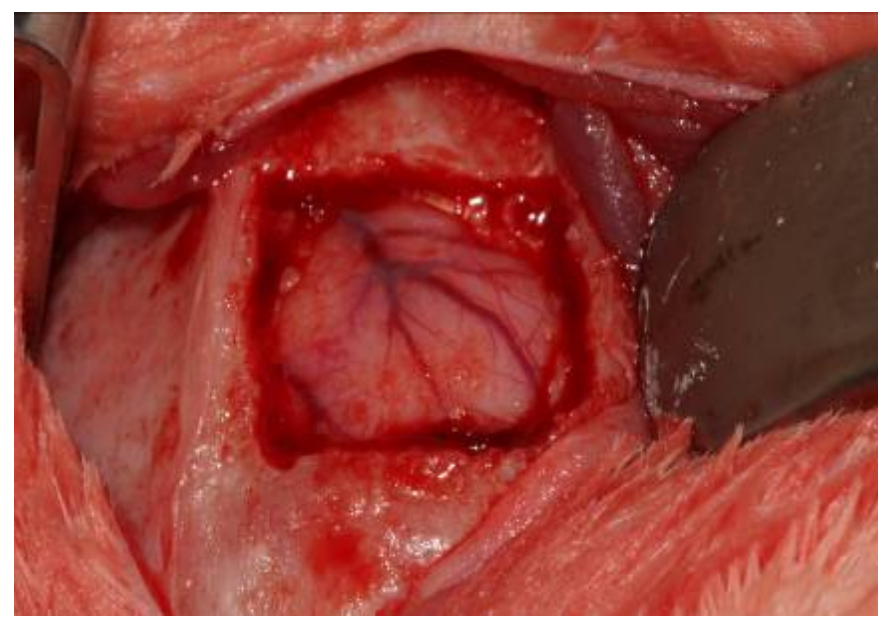

Figura 14 - Aspecto do local da remoção do enxerto visualizando a integridade da dura máter. 
Em seguida, os mesmos procedimentos cirúrgicos foram realizados para obtenção de novo fragmento ósseo, no lado contra-lateral. Após as remoções dos enxertos ósseos, os leitos doadores foram cuidadosamente lavados com soro fisiológico $0,9 \%$ e realizada sutura por planos. O fechamento da ferida foi feito com Vicryl 4.0 no periósteo, fáscia e gálea aponeurótica (Figura 15), e nylon 4.0 na pele, com pontos simples (Figura 16).

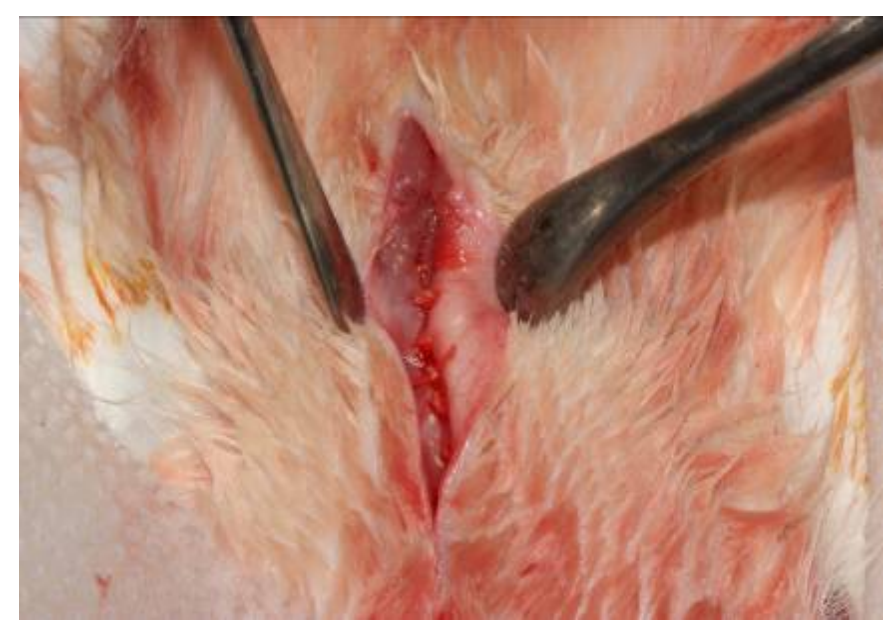

Figura 15 - Sutura de periósteo, fáscia e gálea aponeurótica de calota craniana com Vicryl 4.0.

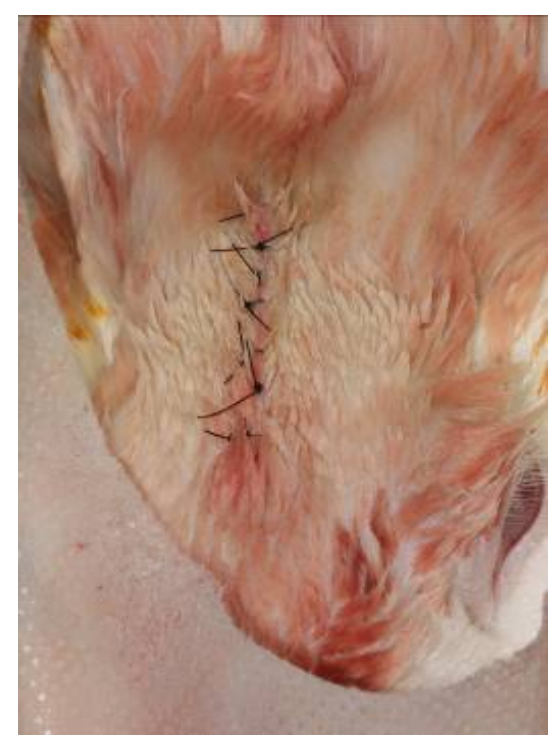

Figura 16 - Sutura de pele de calota craniana com Nylon 4.0. 
Após a coleta dos enxertos ósseos alógenos, os animais doadores foram sacrificados através de sobredose de Tiopental $(2,0 \mathrm{ml})$, administrado por via endovenosa, seguindo critérios do Comitê de Ética em Animais da USP-RP (Protocolo $n^{\circ}$ 07.1.1488.53.6).

Os fragmentos ósseos foram preparados para a transplantação, sendo eliminada qualquer espícula ou ponta óssea através de broca tipo maxcut (Figura 17), com irrigação abundante de soro fisiológico $0,9 \%$ e armazenados em placas de Petri sob cadeia asséptica e encaminhados para a Faculdade de Ciências Farmacêuticas de Ribeirão Preto - USP para a realização de exames microbiológicos, após o procedimento cirúrgico.

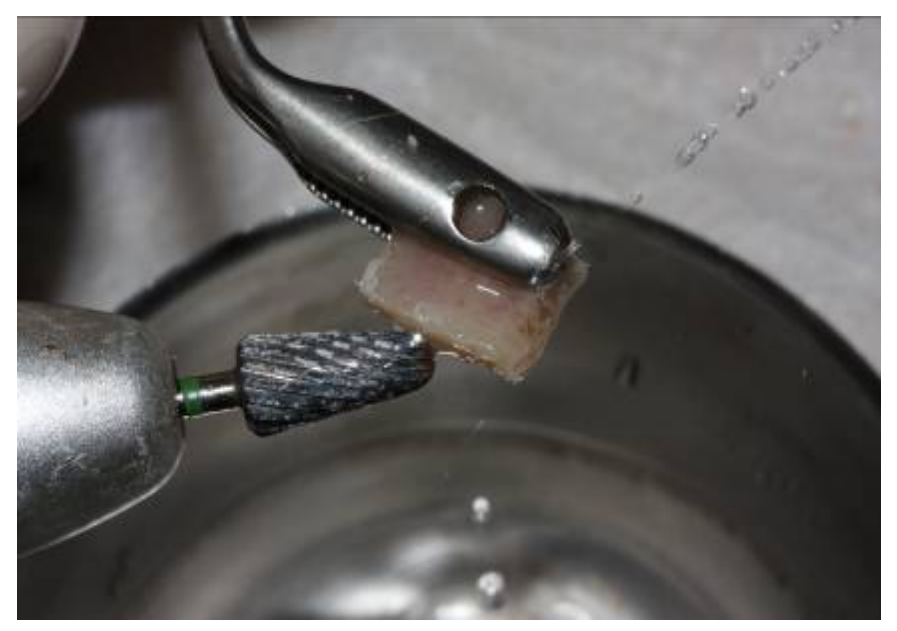

Figura 17 - Remoção de espículas e pontas ósseas com broca tipo maxcut.

Para cada fragmento ósseo coletado foram colhidos três swabs, que foram submetidos à análise microbiológica para fungos e bactérias anaeróbias e aeróbias. Depois de colhido as culturas, o fragmento foi inserido em um saco plástico estéril e lacrado, depois em outro, lacrado e mais um também lacrado (Figura 18). Todos os fragmentos foram armazenados, depois de embalados, em um refrigerador à $-80^{\circ} \mathrm{C}$. (Estes procedimentos são normas exigidas pelo BTME da Universidade de Marília - UNIOSS e regulamentados pelo Ministério da Saúde). 


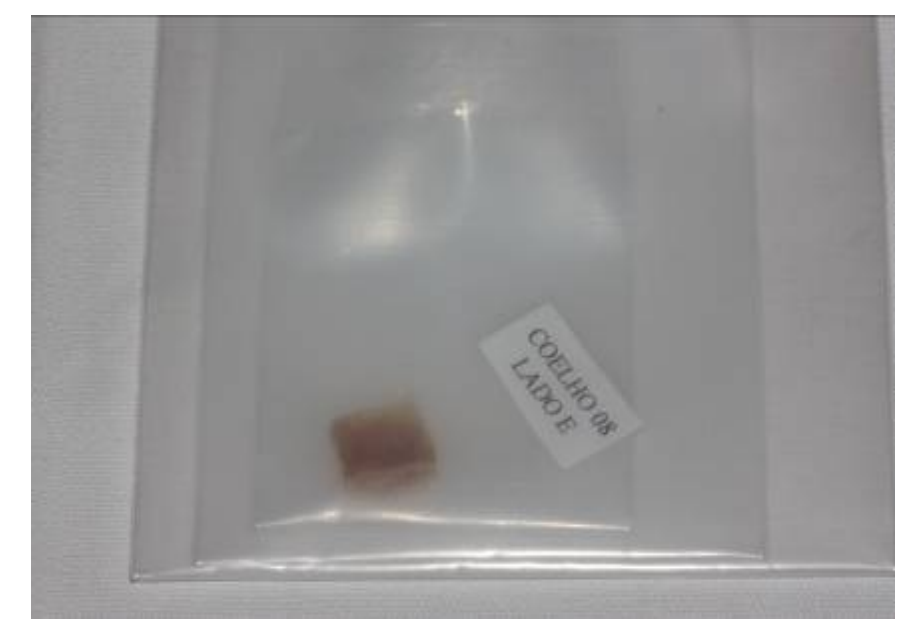

Figura 18 - Embalagem com fragmento ósseo enviado para UNIOSS.

Os resultados das análises microbiológicas de cada fragmento ósseo com resultados negativos foram encaminhados para o BTME da Universidade de Marília - UNIOSS (www.unioss.com.br), onde foram submetidos ao processamento de esterilização seguindo protocolo da entidade citada acima, que segue a Legislação da Resolução da Diretoria Colegiada - RDC N. 220, de 27 de Dezembro de 2006 (www.anvisa.gov.br).

\subsubsection{Obtenção dos enxertos autógenos}

Os enxertos ósseos autógenos foram colhidos da região parietal das calotas dos coelhos $(n=36)$, seguindo os mesmos procedimentos já mencionados para obtenção dos fragmentos ósseos para o enxerto alógeno. Para esses casos, apenas um lado da calota craniana foi removido. Após a realização dessa etapa cirúrgica, o coelho continuava anestesiado para que fosse realizado à enxertia dos blocos ósseos alógeno e autógeno em região mandibular bilateral.

O enxerto removido foi mantido em gaze esterilizada e embebida por solução fisiológica $0,9 \%$ gelada até o preparo do leito receptor. Este mesmo procedimento foi realizado com o bloco ósseo alógeno. 


\subsubsection{Preparo do leito receptor e fixação dos enxertos ósseos alógenos e autógenos}

Os enxertos ósseos alógenos (processados de acordo com o protocolo do BTME da Universidade de Marília - UNIOSS) foram implantados e fixados em um lado da mandíbula dos coelhos receptores $(n=36)$, do outro lado foram implantados e fixados os enxertos ósseos autógenos. $\mathrm{O}$ acesso cirúrgico na mandíbula foi por via submandibular, sendo que duas incisões foram realizadas em direção a base da mandíbula de aproximadamente 1,5 cm (Figura 19).

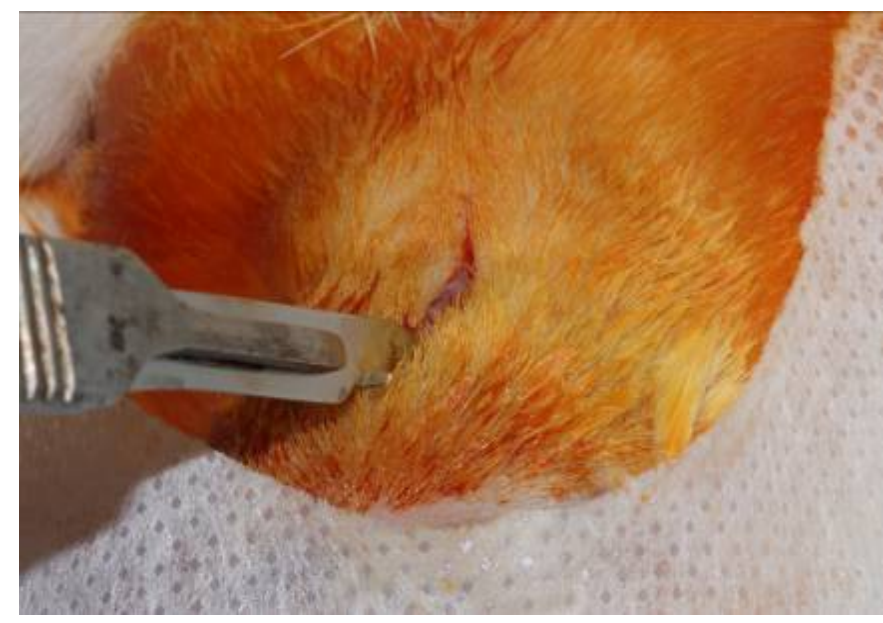

Figura 19 - Incisão linear em pele, em região mandibular.

Estas incisões transpuseram a pele, fáscia, músculo e periósteo até chegar à região de implantação localizada posteriormente a saída do nervo mentual (Figura 20).

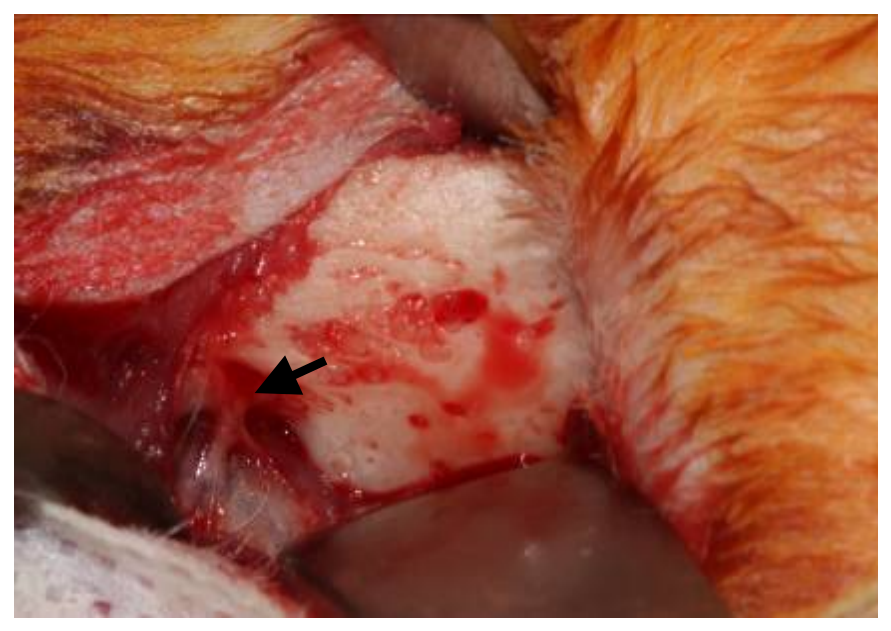

Figura 20 - Descolamento total do retalho e exposição da cortical mandibular. Notar (seta) o nervo mentual localizado ao lado esquerdo da figura. 
Em ambos os lados mandibulares dos coelhos foram confeccionadas perfurações monocorticais dos leitos receptores, visando facilitar a comunicação entre camada trabecular do leito receptor e a cortical do enxerto (PEDROSA JUNIOR et al, 2009) (Figura 22). Tais perfurações foram realizadas sob irrigação abundante com soro fisiológico e a distribuição das mesmas foi padronizada utilizando guia confeccionado em aço cirúrgico (medindo 10x10mm), com nove perfurações de 1,0 $\mathrm{mm}$ de diâmetro, distribuídas de maneira eqüidistante (Figura 21).

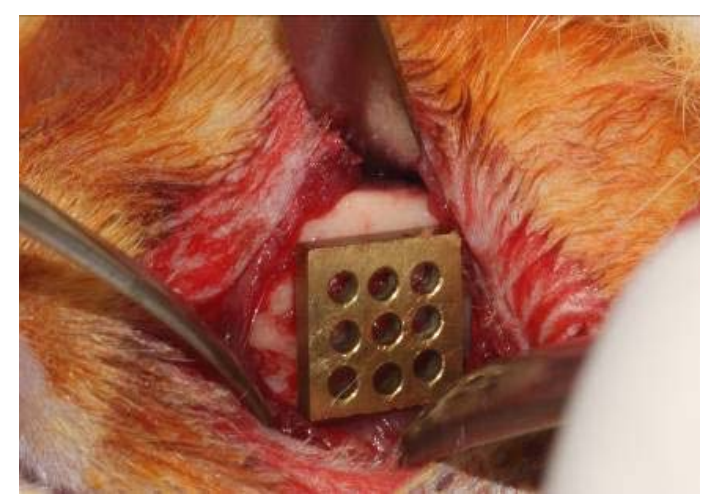

Figura 21 - Adaptação do guia cirúrgico em corpo mandibular para confecção das perfurações.

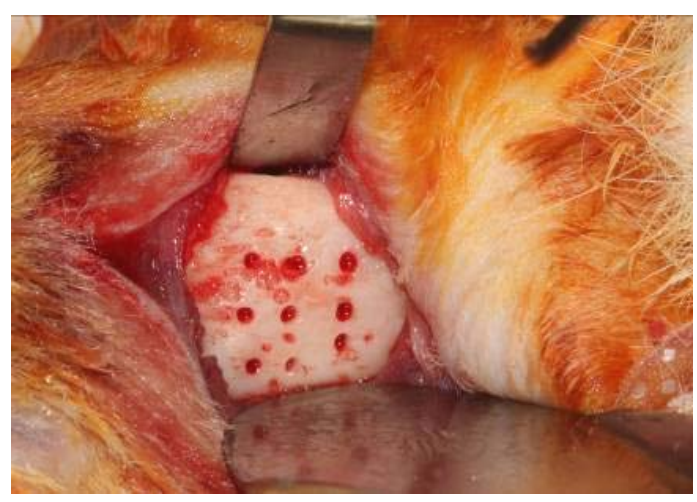

Figura 22 - Perfurações realizadas sob irrigação abundante com soro fisiológico $0,9 \%$ de forma padronizada com a utilização do guia cirúrgico.

De um lado da mandíbula (Grupo I - controle) foi enxertado um bloco ósseo autógeno e do outro (Grupo II) foi enxertado com osso alógeno, sendo de forma aleatória (Figura 23 e 24). Os enxertos foram fixados por meio de parafuso posicional de titânio, medindo $1,5 \mathrm{~mm}$ de diâmetro por 8,0 $\mathrm{mm}$ de comprimento. Para que todos os parafusos fossem inseridos na mesma posição, em todos os enxertos, foi utilizado um guia em aço cirúrgico medindo 10x10mm, para que as perfurações fossem realizadas sempre no centro do mesmo. 


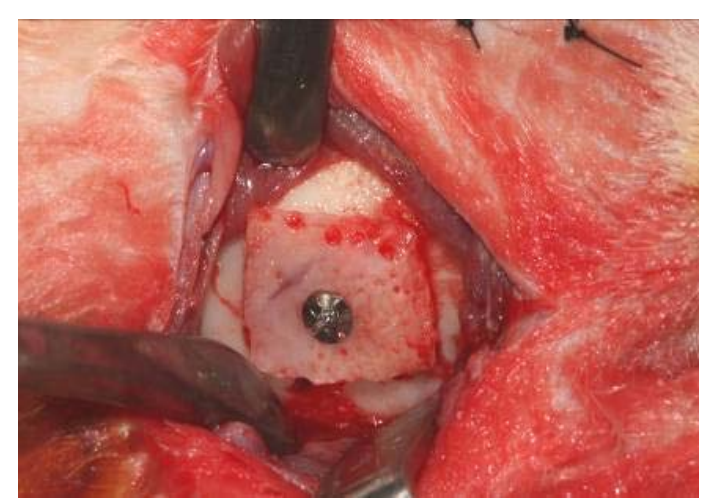

Figura 23 - Osso autógeno enxertado e fixado com parafuso 1,5 X $8,0 \mathrm{~mm}$ em um lado da mandíbula.

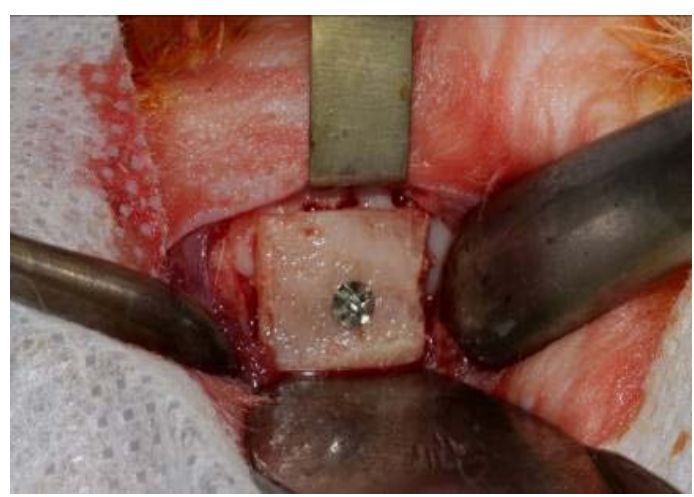

Figura 24 - Osso alógeno enxertado e fixado com parafuso $1,5 \times 8,0 \mathrm{~mm}$ em outro lado da mandíbula.

Após a fixação do enxerto, a ferida cirúrgica foi lavada abundantemente com soro fisiológico $0,9 \%$ e suturada por planos. . O fechamento da ferida foi realizado com Vicryl 4.0 no periósteo e plano muscular (Figura 25), e Nylon 4.0 na pele, com pontos simples (Figura 26).

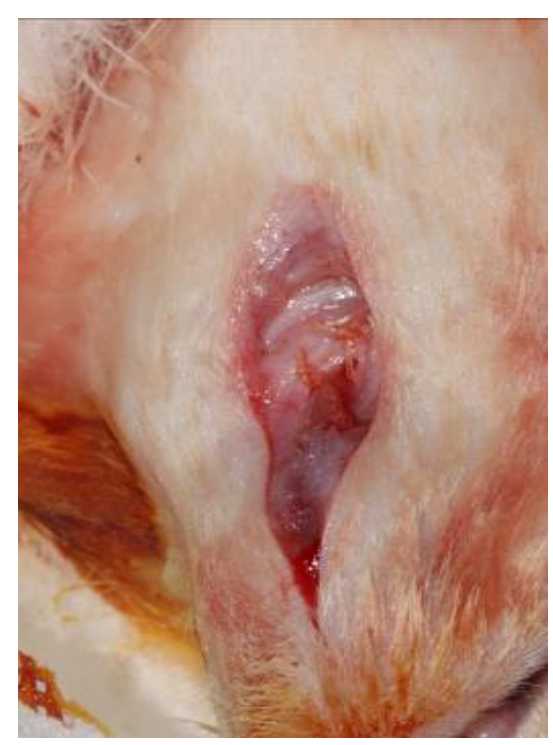

Figura 25 - Sutura por planos (periósteo e músculos) com Vicryl 4.0 em região mandibular. 


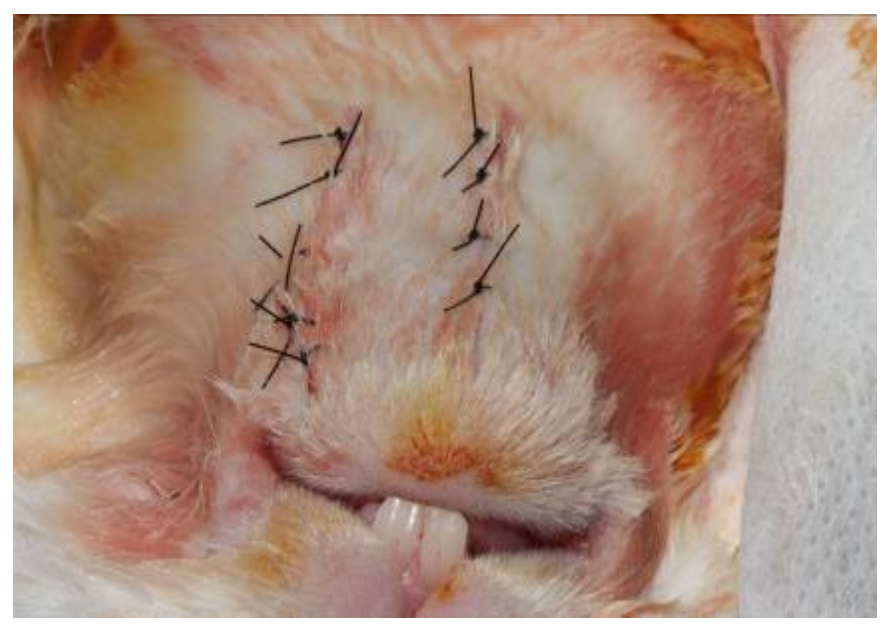

Figura 26 - Sutura bilateral da pele de região mandibular com Nylon 4.0.

Enquanto o coelho encontrava-se ainda sedado, imediatamente após a cirurgia foi realizada a tomografia computadorizada, no Hospital das Clínicas da Faculdade de Medicina de Ribeirão Preto.

Após a tomografia, os coelhos foram mantidos em gaiolas individuais com água e comida à vontade em sala climatizada a $25^{\circ} \mathrm{C}$.

\subsection{Processamento histológico}

A análise histológica teve como objetivo avaliar a incorporação dos enxertos ao leito receptor mandibular, mais especificamente na interface entre o osso enxertado e a mandíbula, fazendo uma análise comparativa entre os dois grupos (Grupo I - autógeno e II - alógeno) das diferentes características teciduais (tais como presença de aposição óssea, reabsorção, reação do periósteo) encontradas nessa interface, no decorrer dos tempos experimentais. No processo de remodelação a qual pode estar relacionado ao fenômeno de reabsorção do enxerto "onlay", observado tanto em enxertos autógenos quanto alógenos, foi analisado se havia diferenças entre o padrão de reabsorção dos enxertos pela quantidade de lacunas de Howship. Obviamente também se observou o padrão de incorporação dos enxertos, que foi avaliado pela presença de osso imaturo (woven bone) entre o leito receptor e o enxerto.

Posterior ao sacrifício do coelho, os segmentos da mandíbula foram removidos, dissecados e reduzidos em blocos individuais contendo os grupos experimentais a serem estudados, respeitando 2,0 $\mathrm{mm}$ das bordas anterior e posterior do enxerto, através de peça reta e disco de carburundum acoplados em motor elétrico, para depois serem processados e 
incluídos em parafina para confecção de lâminas. Imediatamente a redução dos blocos ósseos contendo a área enxertada, estes foram fixados em formalina tamponada 10\% com $\mathrm{pH} 7,4$ (por no mínimo 24 horas). Após a fixação, as peças foram descalcificadas com EDTA 4\% trocado duas vezes por semana. Seguinte a descalcificação, os blocos ósseos foram lavados em água corrente por mais ou menos 08 horas, seguido de desidratação por meio de uma seqüência de alcoóis com concentração crescente (50 a 100\% de 02 em 02 horas). Após desidratação, foi realizada a diafanização com a colocação das peças em xilol (três soluções de 02 em 02 horas) até ficarem transparentes. A seguir, foi então feita a impregnação em parafina, em estufa $60^{\circ} \mathrm{C}$ em três banhos de 3 horas. A próxima etapa constituiu-se na inclusão das peças em formas com parafina, a qual endureceu com as peças totalmente embebidas.

Os blocos de parafina contendo as peças foram cortados em micrótomo de maneira padronizada $(0,5 \mathrm{~mm}$ de espessura), onde foram divididas de maneira intercalada para as análises histológicas e imunohistoquímicas. Para cada peça cortada foram feitas 13 lâminas, sendo 2 para histologia, 9 para imunohistoquímica (8 lâminas para avaliação de 8 proteínas + 1 lâmina para controle negativo) e 2 reservas. As lâminas destinadas à análise histológica foram coradas com Tricrômio de Mallory (Figura 27).

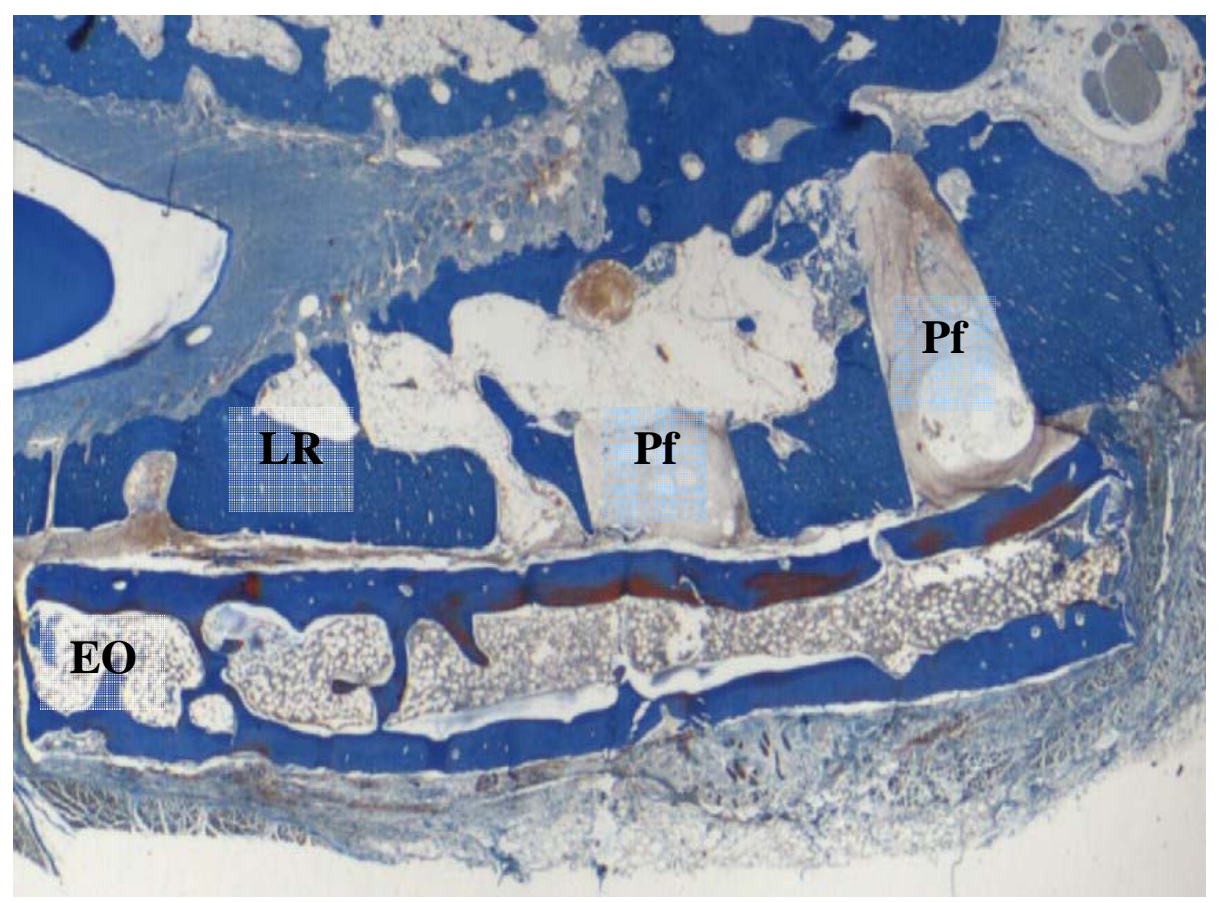

Figura 27 - Corte histológico corado em Tricrômio de Mallory. Nesta fotomicrografia podemos observar o enxerto ósseo (EO) posicionado no leito receptor (LR) com presença de duas perfurações. $\mathrm{PF}=$ perfurações. (5x). 


\subsection{Processamento para imunohistoquímica}

Já na análise imunohistoquímica foram realizadas marcações com o método de detecção por imunoperoxidase. A angiogênese no interior do enxerto e interfaces ósseas foram avaliadas por meio de marcações de VEGF, enquanto o processo de absorção e aposição ósseas foram reconhecidas através de marcações de Receptor Activator of Nuclear Factor-k $\beta$ ligand (RANKL), Tartrate-Resistant Acid Phosphatase (TRAP), Osteoprotegerina(OPG), Osteocalcina (OC), Osteopontina (OPN), Colágeno Tipo I (COL I) e Fosfatase Alcalina (ALP).

Para isto utilizou-se anticorpos primários das seguintes porteínas: anti-OC produzido em cabra (SC 18319 - Santa Cruz Biotechnology); anti-OPN produzido em cabra (SC 10593 - Santa Cruz Biotechnology); anti-COL I produzido em cabra (SC 8758 - Santa Cruz Biotechnology); anti-VEGF produzido em rato (SC 507 - Santa Cruz Biotechnology); antiALP produzido em cabra (SC 23430 - Santa Cruz Biotechnology); anti-TRAP produzido em cabra (SC 30832 - Santa Cruz Biotechnology); anti-RANKL produzido em cabra (SC 7627 Santa Cruz Biotechnology) e anti-OPG produzido em cabra (SC 21038 - Santa cruz Biotechnology). As titulações para cada anticorpo primário foram padronizadas conforme orientações do laboratório que as produziu. Como anticorpo secundário, foi utilizado o anticorpo biotinilado anti IgG de cabras e produzidos em burros (706-065-147 - Jackson Immunoresearch Laboratories) na titulação de 1:200 (Figura 28).

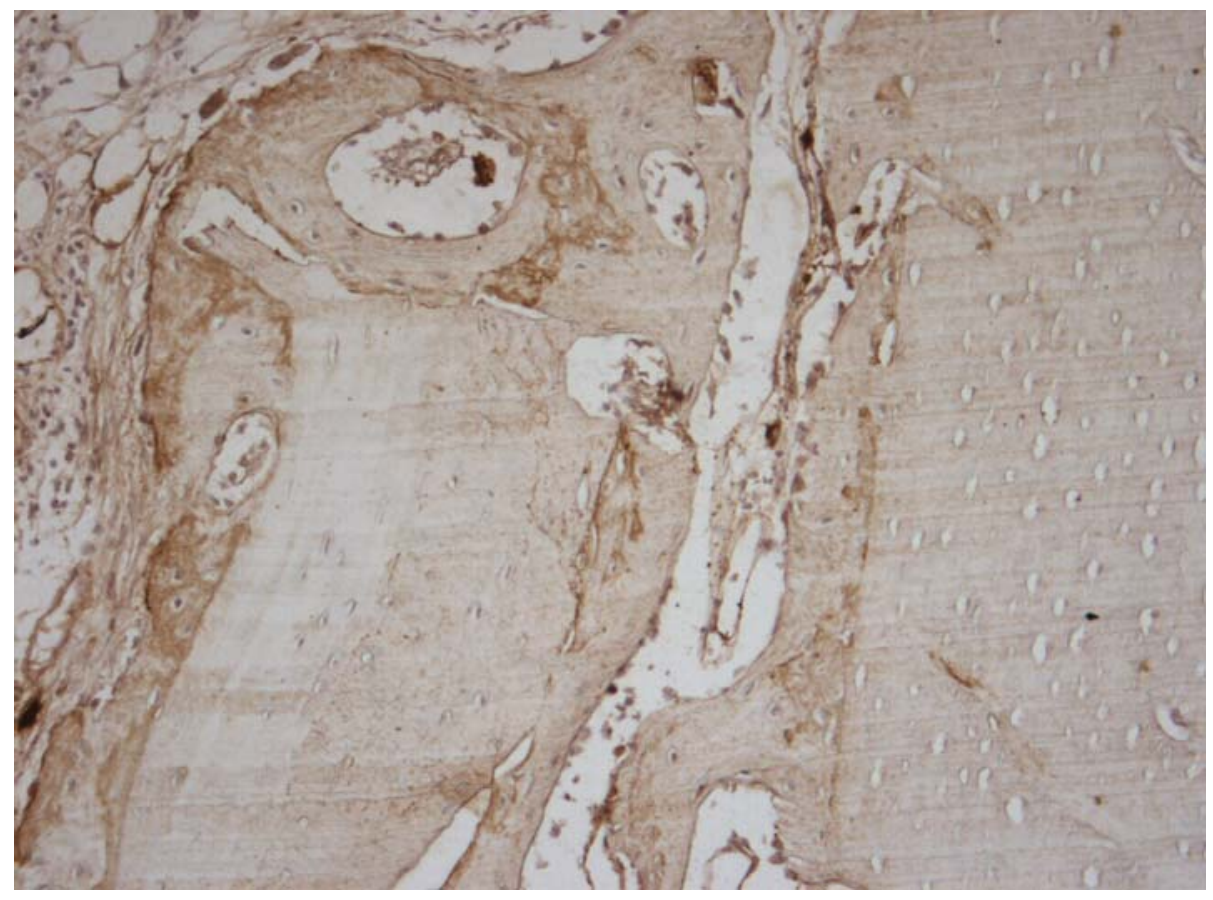

Figura 28 - Marcação imunohistoquímica para proteína OPN Enxerto Autógeno. (100x) 
A peroxidase endógena foi bloqueada pela incubação das lâminas com peróxido de hidrogênio 3\% em PBS por 50 minutos, seguida pela recuperação de epítopos por aquecimento em tampão citrato de sódio $0,05 \mathrm{M}, \mathrm{pH} 6,0$, a $65^{\circ} \mathrm{C}$ por 20 minutos. Por último, a biotina endógena, foi bloqueada pela incubação em solução com avidina (leite Molico 3\%) por 20 minutos. $\mathrm{O}$ anticorpo primário foi incubado por 18 horas a $4^{\circ} \mathrm{C}$. O passo seguinte foi a incubação com o anticorpo secundário biotinilado anti-imunoglobulina de cabra por $1 \mathrm{~h}$, à temperatura ambiente. Ato contínuo, as lâminas foram incubadas com o complexo avidinabiotina-peroxidase (Duet Kit, Dako), à temperatura ambiente por 60 minutos. Por último para revelar a imunomarcação foi usado como cromógeno a DAB (3,3'-diaminobenzidina tetrahidrocloridrato) e a hematoxilina de Harris como contra marcação.

Para esta avaliação foi construída uma tabela de escores que variou de 1 a 4 , de maneira subjetiva e semi-quantitativa, com a qual quantificou-se as marcações imunohistoquímicas como ausente, pouca, moderada e intensa, respectivamente. Estes valores puderam ajudar a mapear os eventos biomoleculares em que a enxertia óssea foi submetida na qual estas proteínas supracitadas estavam envolvidas (osteogênese, osteoclastogênese e revascularização). A análise foi realizada de maneira padronizada, próximo às margens do enxerto, na sua superfície e na interface, por recuperação de imagem em microscópio Leica DMLB light microscope (Leica, Bensheim, Germany) em objetiva com aumento de 100X, por um único observador de maneira duplo cega.

\subsection{Tomografia Computadorizada}

Os exames tomográficos foram realizados imediatamente após as cirurgias de implantação dos enxertos e também após os sacrifícios, com finalidade de analisar o comportamento dos enxertos ósseos em relação à densidade e ao volume. Os cortes tomográficos foram analisados nos softwares Dicom Works e e-Film Workstation, para análises volumétrica e de densidade óssea, respectivamente.

Os exames foram realizados sob sedação endovenosa em equipamento de tomografia computadorizada helicoidal modelo Emotion ${ }^{\mathrm{TM}}$ (Siemens, Elrlangen, Germany), instalado no Hospital das Clínicas da Faculdade de Medicina de Ribeirão Preto - USP. Foram realizados aquisição volumétricas helicoidais no plano axial à mandíbula do animal e ao enxerto, com $110 \mathrm{KV}$ e $60 \mathrm{MAS}$, com "rotation time" de 1 segundo, incremento contínuo da mesa de $2 \mathrm{~mm}$ e espessura de corte de $1 \mathrm{~mm}$. A reconstrução foi de $1,0 \mathrm{~mm}$ de espessura, com filtro de alta 
resolução espacial ("Sharp"), matriz 512x512 e campo de visão (FOV) de 150 mm, resultando num tamanho de voxel de 0,5x0,3x0,3 mm (Figura 29) .

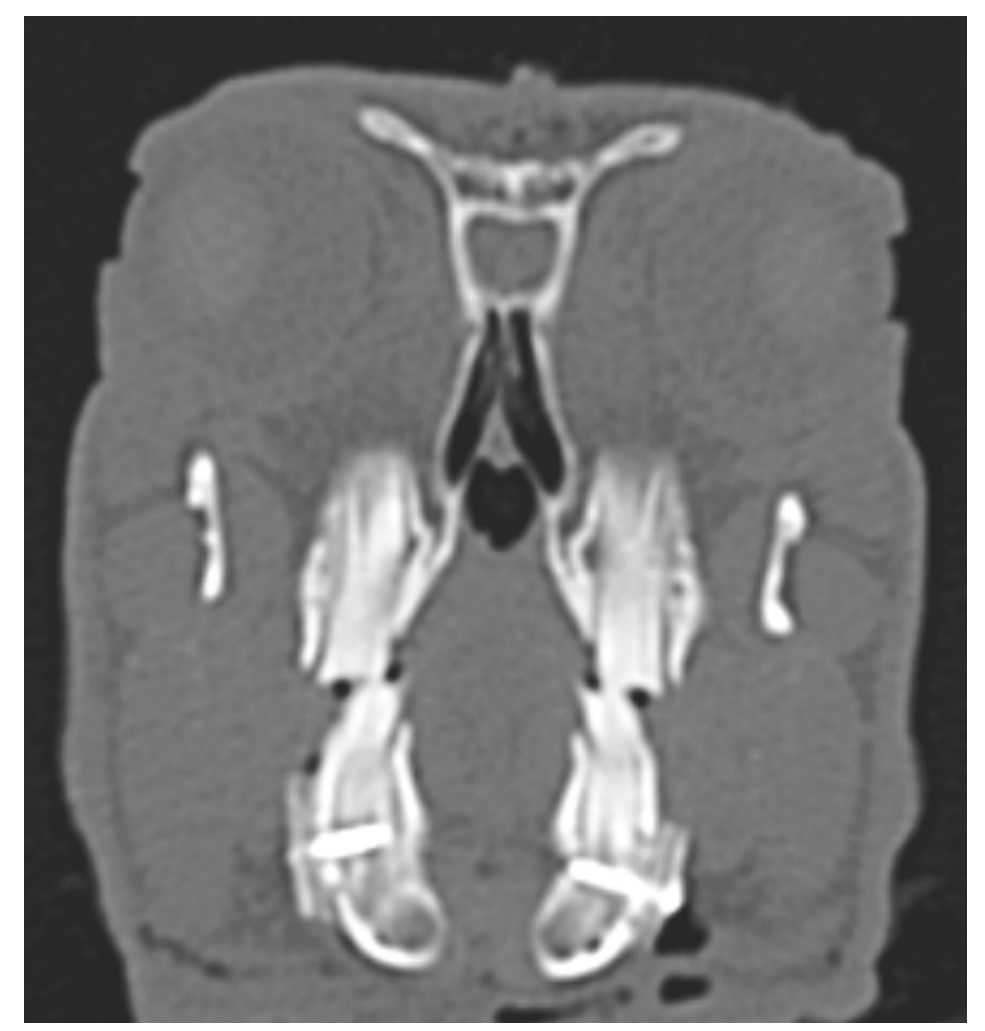

Figura 29 - Tomografia computadorizada em corte coronal.

As imagens foram geradas em padrão DICOM e transferidas para uma "Workstation PC" para visualização e realização de medidas de densidade e volume do enxerto e de porções deste. As medidas de densidade foram obtidas em unidades Hounsfield e em milímetros para os parâmetros de tamanho.

\subsubsection{Cálculo do volume do enxerto}

Utilizando o software Dicom Works v.1.3.5, a imagem do enxerto foi delimitada através da ferramenta "Surface", a qual ao término da demarcação do enxerto o programa automaticamente nos proporciona medidas em $\mathbf{c m}^{2}$ Para obtermos um volume em $\mathbf{~ m m}^{3}$, foi necessário inicialmente transformar $\mathbf{c m}^{2} \mathrm{em} \mathbf{m m}^{2}$, pois os cortes tomográficos são realizados a cada $01 \mathrm{~mm}$ (Figura 30). 
Estas demarcações foram realizadas em todos os corte em que o enxerto é visualizado, totalizando num número de 08 cortes, sendo que no final a soma de todos os valores multiplicada pelo número de cortes foi o valor do volume do enxerto em $\mathbf{~ m m}^{3}$. Esta análise foi realizada pelo mesmo examinador de maneira duplo cega.

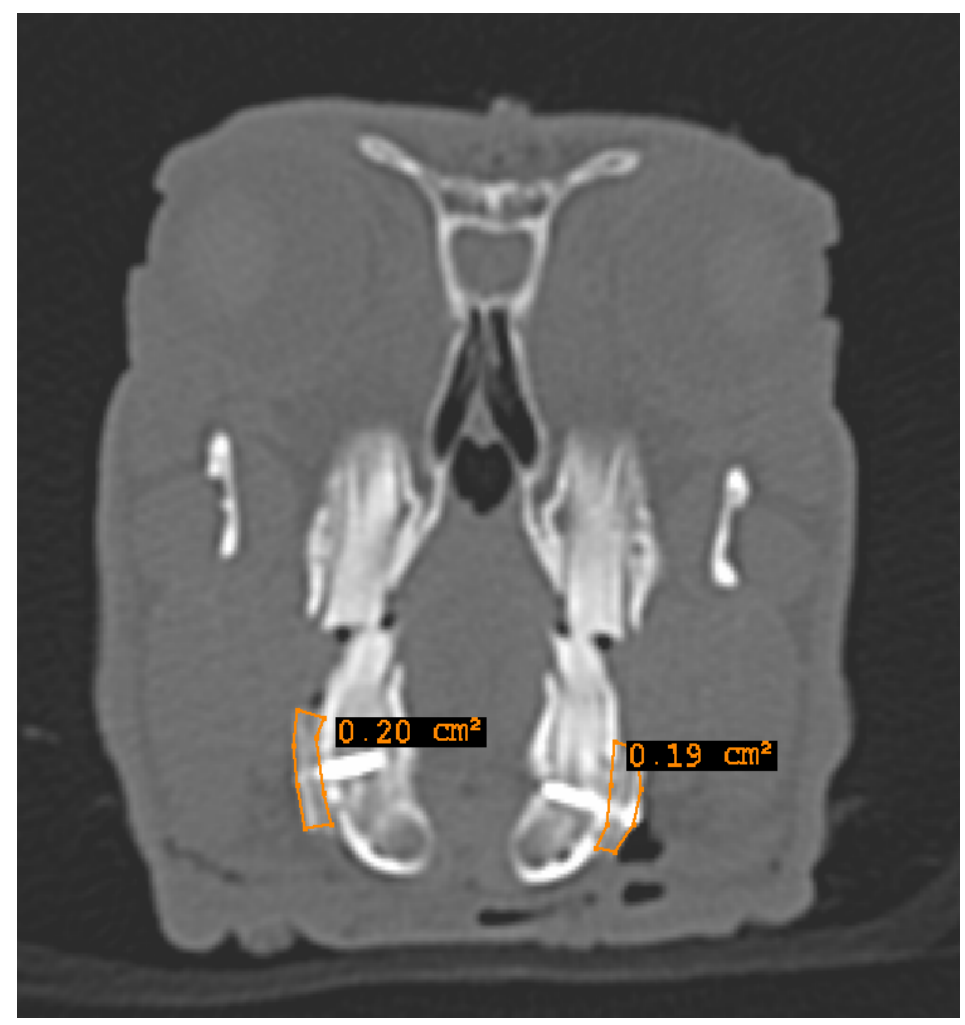

Figura 30 - Corte tomográfico no plano coronal com mensuração de volume pelo software Dicom Works $1.3 .5 \mathrm{~b}$.

\subsubsection{Cálculo da densidade do enxerto}

Os dados obtidos com os exames tomográficos foram expressos em unidades Hounsfield - medida de densidade relativa à densidade da água e do ar. A calibração do aparelho foi realizada previamente aos exames e os dados obtidos foram validados clinicamente, com garantias de mensuração fidedigna da densidade tecidual. Utilizando o software e-Film Workstation (http://www.merge.com/products/efilmworkstation.asp) que fornece a opção de estabelecer uma "região de interesse" (ROI) de forma elíptica, foram realizadas medidas de densidade do enxerto para cada corte tomográfico $(1,0 \mathrm{~mm})$. Em cada 
corte foi estabelecida a densidade em posição superior e inferior ao parafuso (Figura 31). Para esta análise foi considerado 05 cortes tomográficos mais centrais (mais próximos ao parafuso), os quais davam condições de avaliação na porção superior e inferior do parafuso. A localização e dimensão do ROI foram padronizadas e realizadas por apenas um avaliador de maneira duplo cega e repetidas 05 vezes para cada animal com intuito de minimizar os erros.

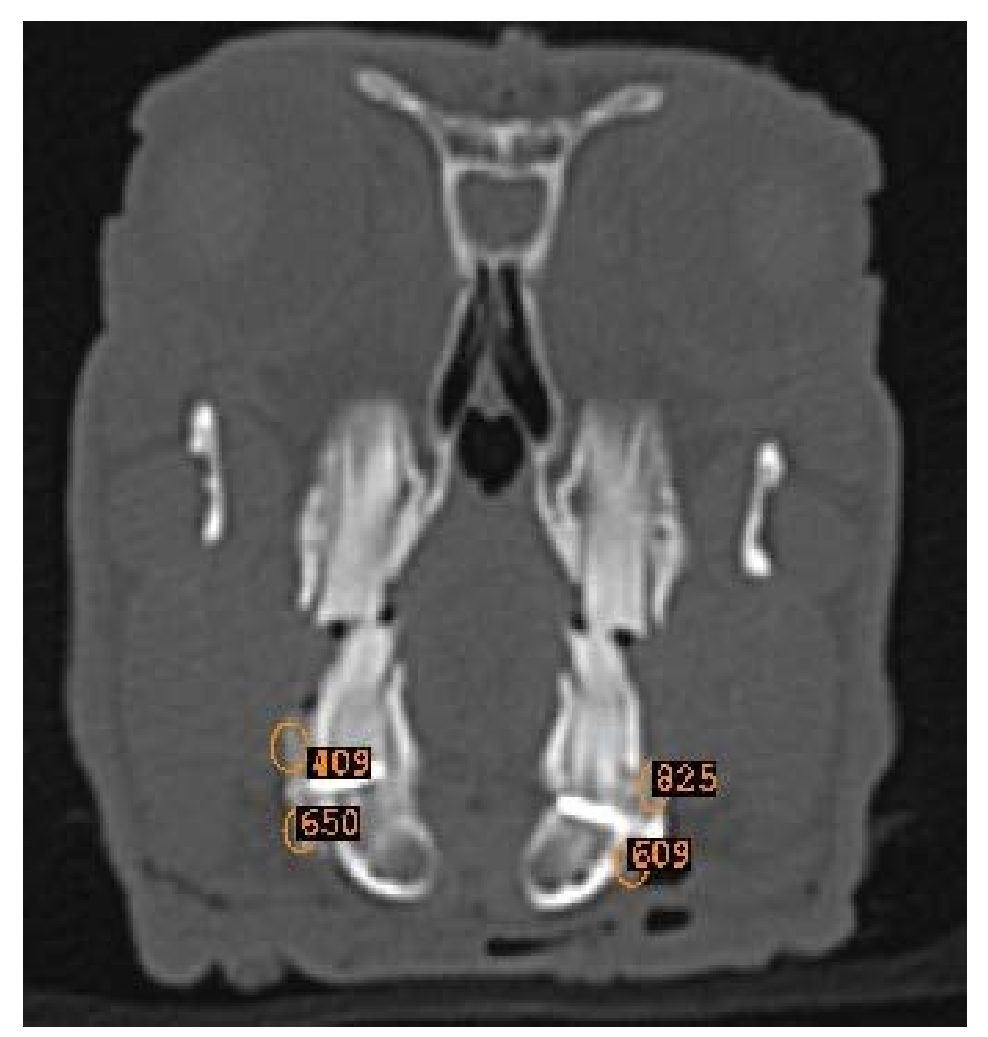

Figura 31 - Marcações das densidades em posição superior e inferior ao parafuso. Cada posição possui uma densidade média, sendo que a densidade do corte foi a média das densidades.

\subsection{Análise estatística}

Os dados quantitativos foram descritos em tabelas e gráficos pelos parâmetros de média e desvio padrão. Os dados em escore foram descritos pela média, mediana, $1^{\circ}$. quartil e $3^{\circ}$. quartil.

O objetivo da avaliação dos dados tomográficos foi verificar o comportamento do enxerto alógeno em comparação com o enxerto autógeno. Para isso, observamos o volume e a 
densidade destes enxertos ósseos em tempos definidos: 03, 05, 07, 10, 20 e 60 dias. Sempre avaliando em cada coelho uma tomografia antes (imediatamente após a cirurgia) e uma depois (após o sacrifício, de acordo com cada tempo experimental). Observamos também se houve evidências estatísticas quando se comparou o enxerto alógeno com o enxerto autógeno. $\mathrm{O}$ teste $\mathrm{T}$ pareado foi utilizado para comparar as medidas de volume e de densidade dos enxertos entre a fase inicial (antes) e de sacrifício (depois). Para a comparação das variações de volume e densidade ocorridas entre os grupos alógenos e autógenos e entre os 06 tempos de avaliação foi utilizado Análise de Variância a dois critérios modelo misto.

Em relação aos dados da marcação imunohistoquímica foram utilizados testes não paramétricos na análise. Para comparação entre os grupos alógeno e autógeno foi utilizado o teste de Wilcoxon e para a comparação entre os 06 tempos de avaliação foram utilizados os testes de kruskal-Wallis e Post Hoc de Dunn. As concentrações das proteínas foram avaliadas através de escores variando de ausente (1); pouco (2); moderado (3); e intenso (4). Com isso, foi possível comparar a ocorrência dessas proteínas em ambos os grupos e em diferentes tempos.

Em todos os testes estatísticos foi adotado nível de significância de 5\% $(p<0,05)$. Todos os procedimentos foram executados no programa Statistic for Windows versão 5.1 (Stat Soft Inc. Tulsa, USA). 


\section{RESULTADOS}

Todos os animais suportaram bem os procedimentos cirúrgicos e o pós-operatório ocorreu sem maiores complicações. Ausência de sinais de infecção que comprometesse as avaliações histológicas, tomográficas e imunhistoquímicas.

Foram realizadas imunomarcações para VEGF com o objetivo de se avaliar o processo de revascularização, utilizando-se o anticorpo monoclonal anti VEGF da Santa Cruz Biotechnology. Vale destacar que este mesmo anticorpo monoclonal foi utilizado para realizar imunomarcações para VEGF em trabalhos anteriores seguindo a mesma linha de pesquisa. No entanto, a característica do anticorpo monoclonal é a sua ligação específica em apenas um epítopo do antígeno a ser marcado, diferente dos anticorpos policlonais, que se ligam a vários epítopos do antígeno de interesse. No caso dos experimentos anteriores, os cortes histológicos foram obtidos pela técnica de congelação, método que favorece a preservação dos epítopos. No presente experimento, os cortes histológicos foram obtidos pela inclusão em parafina e neste caso o processamento imunoistoquímico exige etapas de desparafinização (cortes levados a altas temperaturas, banhos de xilol e álcool), além da etapa de recuperação antigênica, realizada no aquecimento a vapor. Consideramos que todas estas manobras inativaram o epítopo ao qual se ligaria o anticorpo monoclonal contra VEGF e por esse motivo não foram observadas imunomarcações para este fator de crescimento com o nosso anticorpo. 


\subsection{Análises histológicas}

\subsubsection{Reação do periósteo}

No tempo 3 dias o periósteo na região periférica dos enxertos ósseos apresentou-se em grande parte íntegro, com as fibras pouco desorganizadas, principalmente no grupo autógeno. Nesse momento, não encontramos formação óssea evidente em nenhum dos dois enxertos.(Figura 32 e 33).
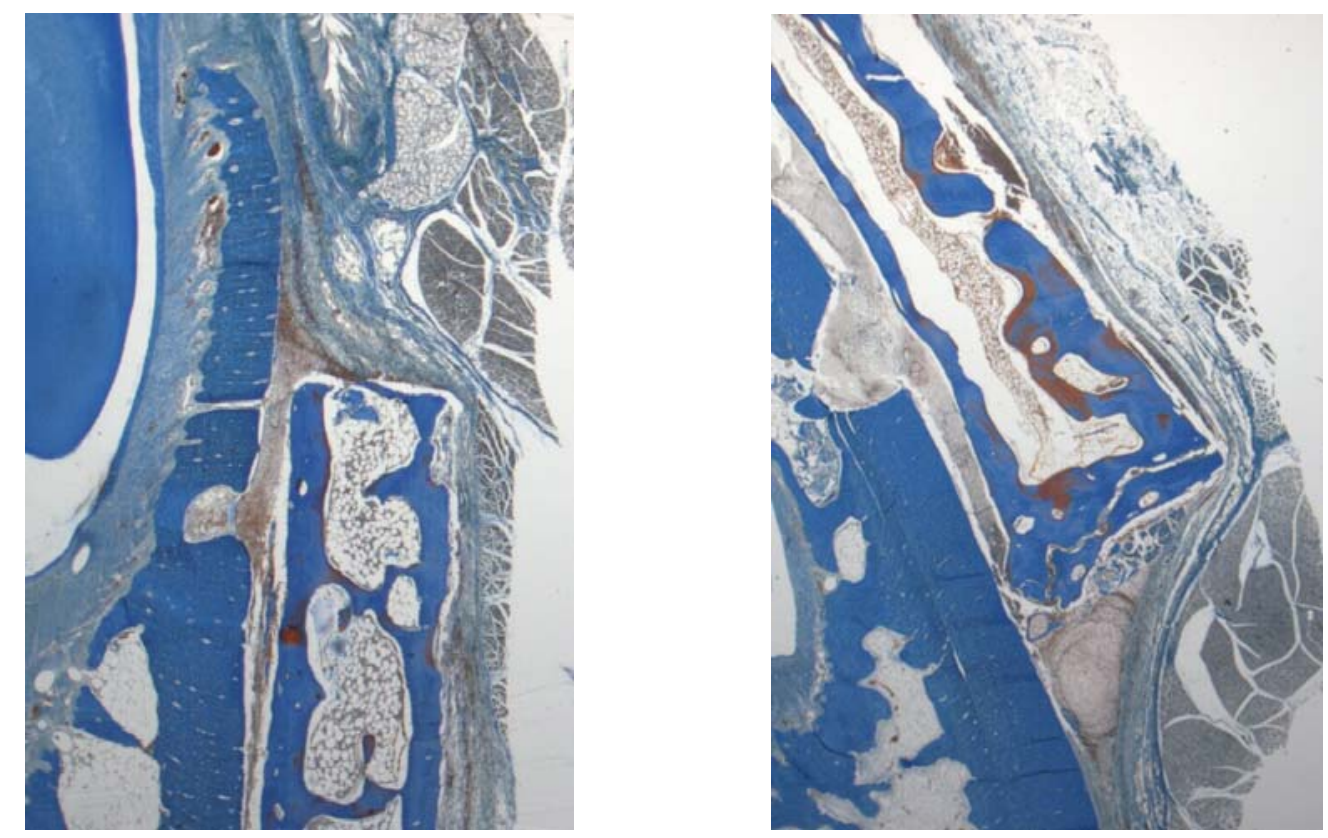

Figura 32 e 33 - Fotomicrografia de um sítio com enxerto autógeno (lado esquerdo) e alógeno (lado direito). Em ambos os enxertos observamos a presença do periósteo, porém com as fibras mais organizadas e evidentes no grupo autógeno. (16x). Tricrômio de Mallory. 
No período de 05 dias, o comportamento do periósteo continua semelhante ao tempo experimental anterior. Neste momento, as fibras do periósteo estão mais organizadas e o enxerto já está todo coberto pelo periósteo (Figura 34 e 35).
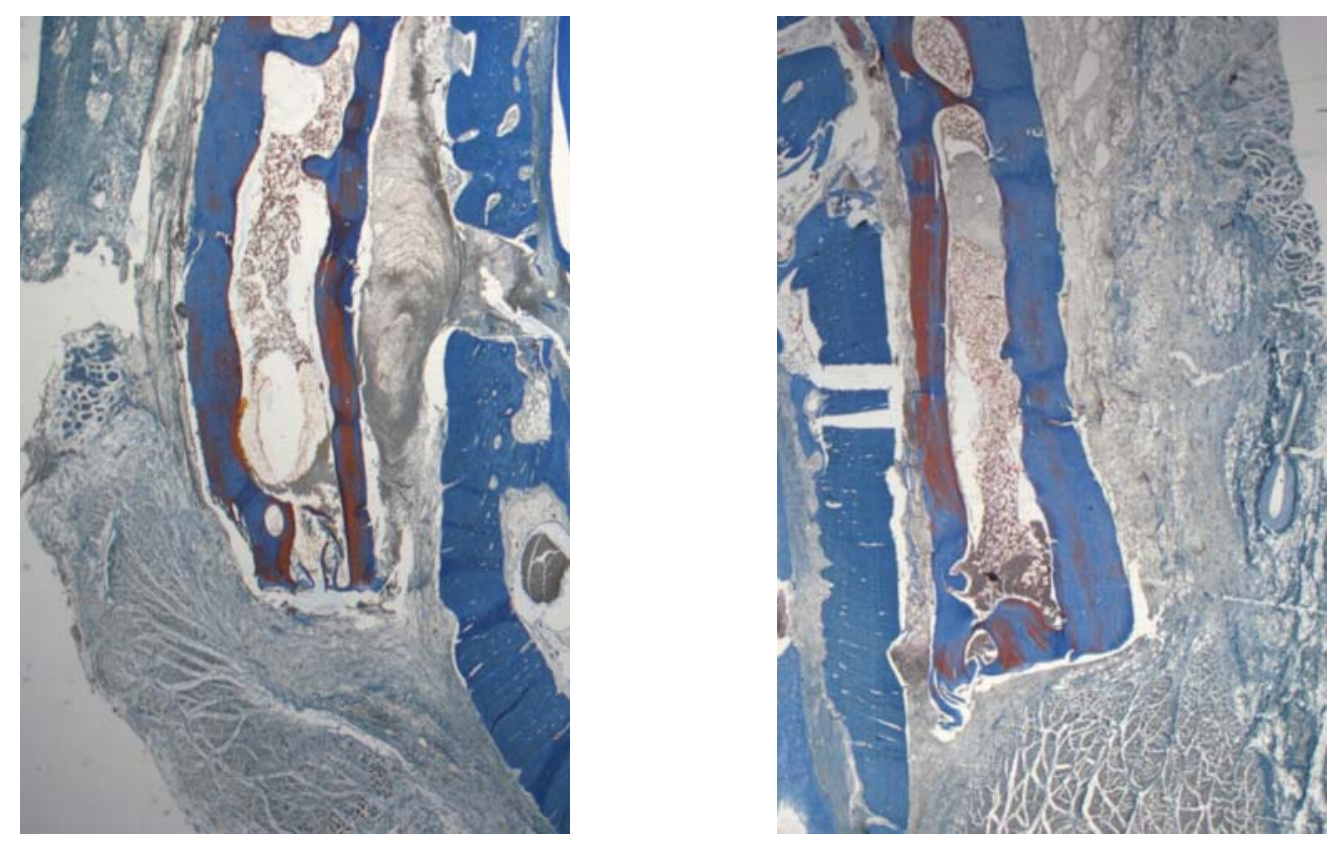

Figura 34 e 35 - Fotomicrografia de um sítio com enxerto autógeno (lado esquerdo) e alógeno (lado direito). Em ambos enxertos observamos a integridade do periósteo. As fibras estão mais organizadas. Há pouca diferença entres ambos os grupos. (16x). Tricrômio de Mallory. 
Em 07 dias, observamos que abaixo do periósteo na região periférica, próxima a borda do enxerto, há início da formação óssea, com presença de osso imaturo. Observa-se que essa formação é bem intensa no grupo alógeno. Neste período o periósteo está completamente regenerado (Figura 36 e 37).
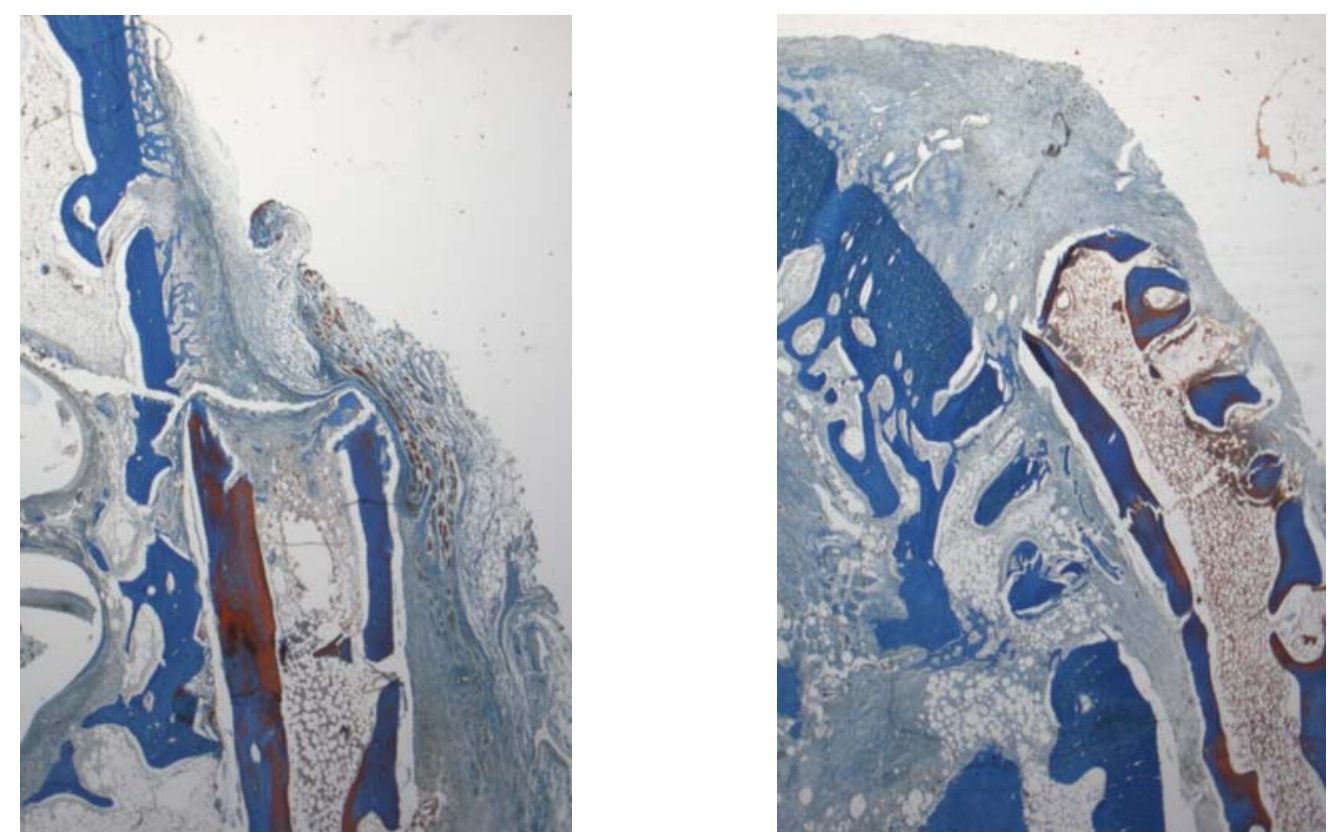

Figura 36 e 37 - Fotomicrografia de um sítio com enxerto autógeno (lado esquerdo) e alógeno (lado direito). Presença de formação óssea abaixo do periósteo mais intensa no grupo autógeno. Principal diferença entre os dois grupos no período experimental de 07 dias. (16x). Tricrômio de Mallory. 
Aos 10 dias, os sítios de enxerto autógeno revelam uma formação óssea oriunda do periósteo que avança em direção ao enxerto. Estabelece-se o início da união do enxerto ao leito receptor através das pontes ósseas, sendo essa união mais intensa próxima ao periósteo. Para o enxerto alógeno, observamos a mesma formação óssea originária do periósteo para a interface (Figura 38 e 39).
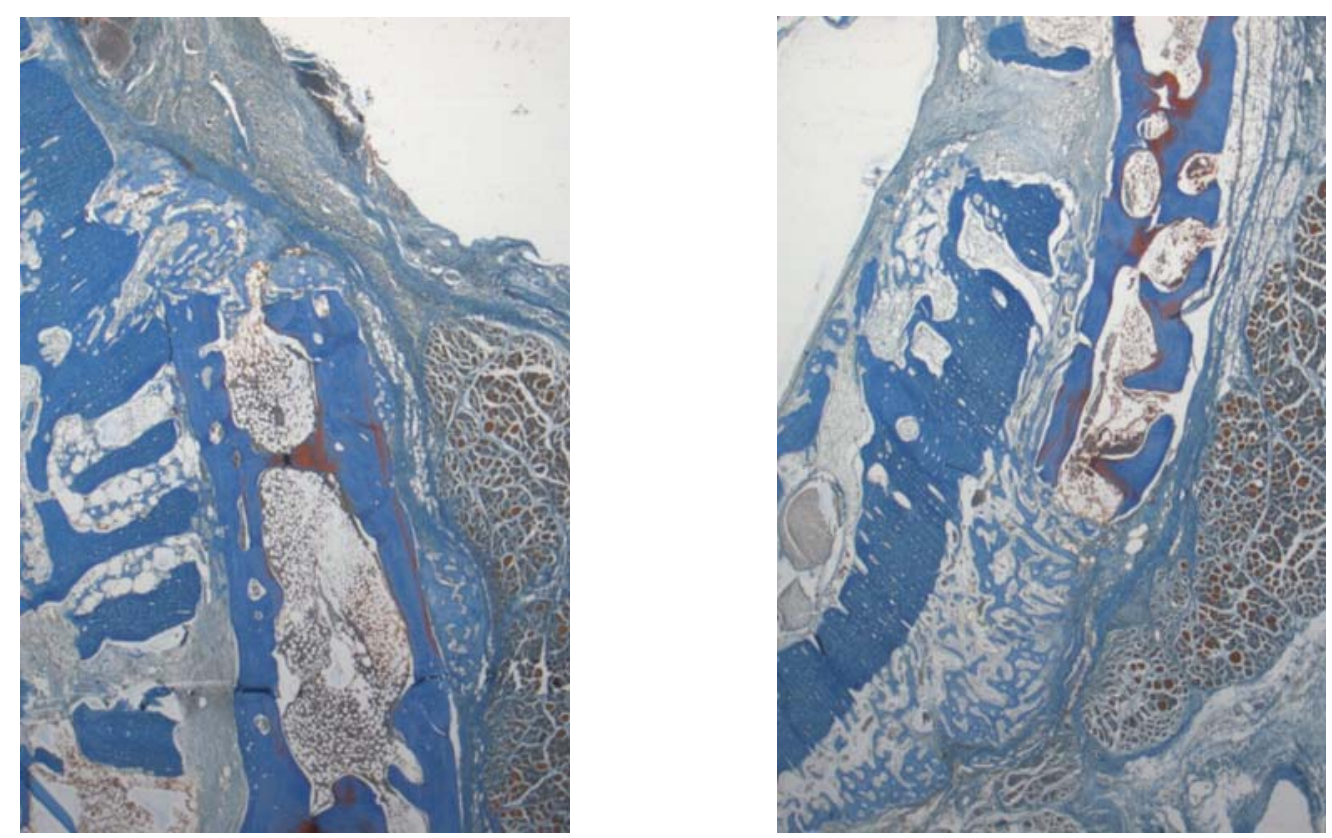

Figura 38 e 39 - Fotomicrografia de um sítio com enxerto autógeno (lado esquerdo) e alógeno (lado direito). Observa-se em ambos os grupos a formação óssea abaixo do periósteo alcançado a interface enxerto e leito receptor. Observar no enxerto autógeno que há formação óssea na região cortical ao enxerto. (16x). Tricrômio de Mallory. 
No período de 20 dias encontramos uma neoformação óssea mais intensa que no tempo experimental anterior, com uma integração com a neoformação óssea da interface entre o enxerto ósseo e o leito receptor. Essa formação óssea é mais intensa no grupo autógeno, onde há um envolvimento quase que total das bordas periféricas do enxerto, enquanto que no grupo alógeno, as bordas continuam íntegras com pouca formação óssea associada (Figura 40 e 41).
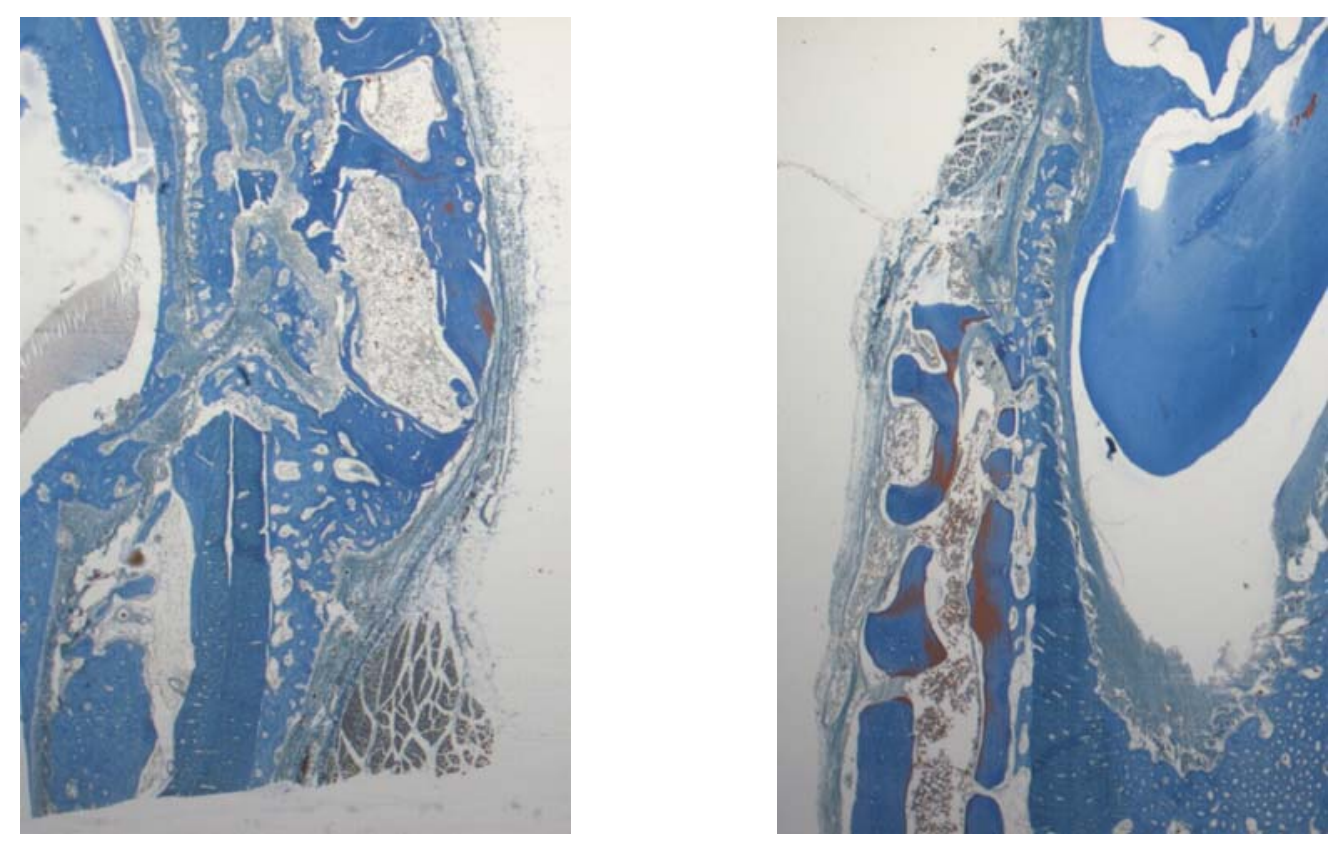

Figura 40 e 41 - Fotomicrografia de um sítio com enxerto autógeno (lado esquerdo) e alógeno (lado direito). No tempo de 20 dias, observar-se que há uma formação óssea, integrada com a formação óssea da interface. No grupo autógeno a neoformação óssea envolve grande parte do enxerto ósseo, enquanto que no grupo alógeno esse envolvimento é menos intenso. (16x). Tricrômio de Mallory. 
Em 60 dias, a formação óssea atingiu seu ápice, pois o osso formado encontra-se maduro. No grupo autógeno estabelece-se a fusão do enxerto ao leito receptor, na interface e na periferia do enxerto, abaixo do periósteo. No grupo alógeno, essa união é menos intensa e o enxerto não está integrado ao osso neoformado (Figura42 e 43).
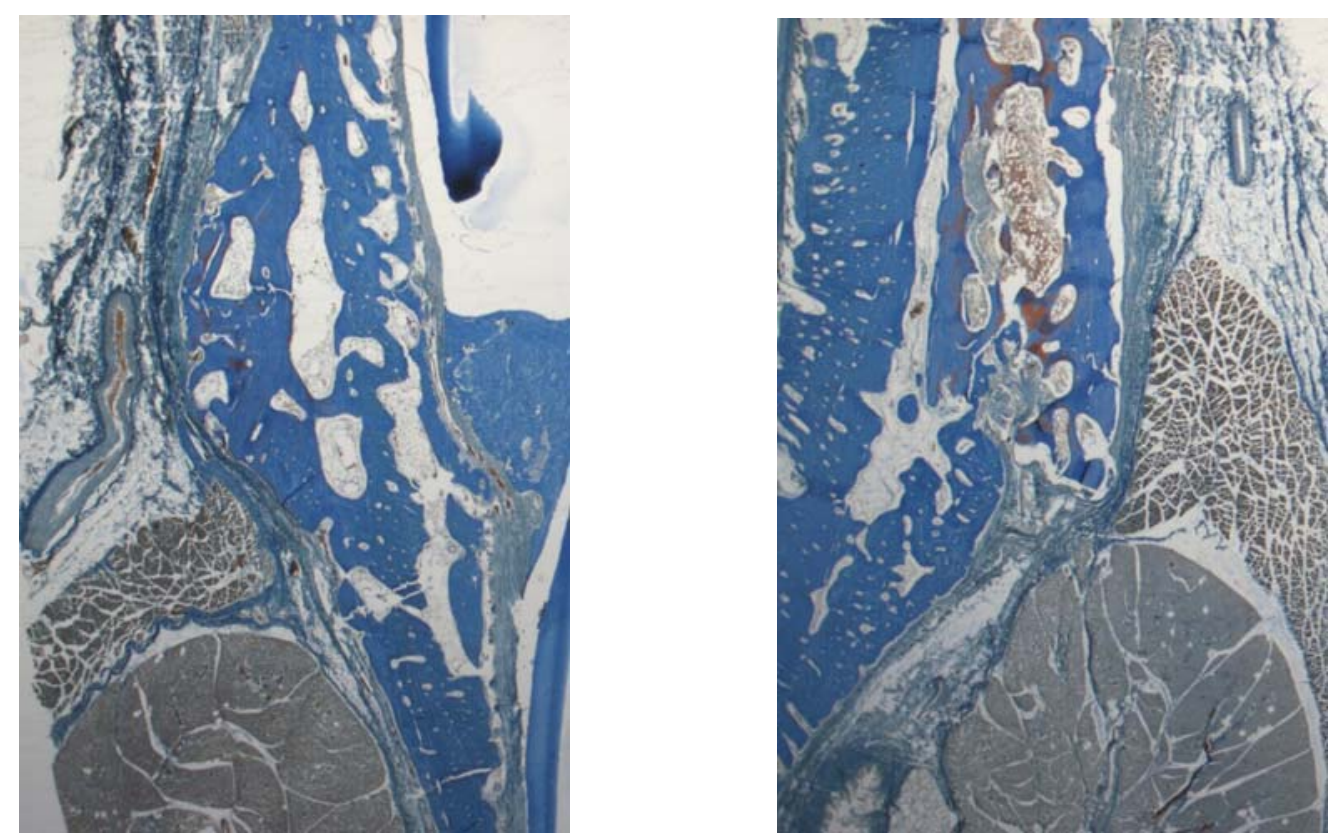

Figura 42 e 43 - Fotomicrografia de um sítio com enxerto autógeno (lado esquerdo) e alógeno (lado direito). Em ambos os grupos encontra-se um osso maduro, no entanto em uma quantidade maior no grupo autógeno. (16x). Tricrômio de Mallory. 


\subsubsection{Enxerto autógeno}

No período experimental de 3 dias, observamos grande quantidade de infiltrado celular com maior presença de hemácias, pequena quantidade de proliferação celular, com baixa diferenciação das células participantes da osteogênese e osteoclastogênese. O periósteo apresentou-se com certa integridade. Encontramos no enxerto presença de vasos sanguíneos, lacunas de osteócitos com células viáveis e células adiposas (Figura 44).

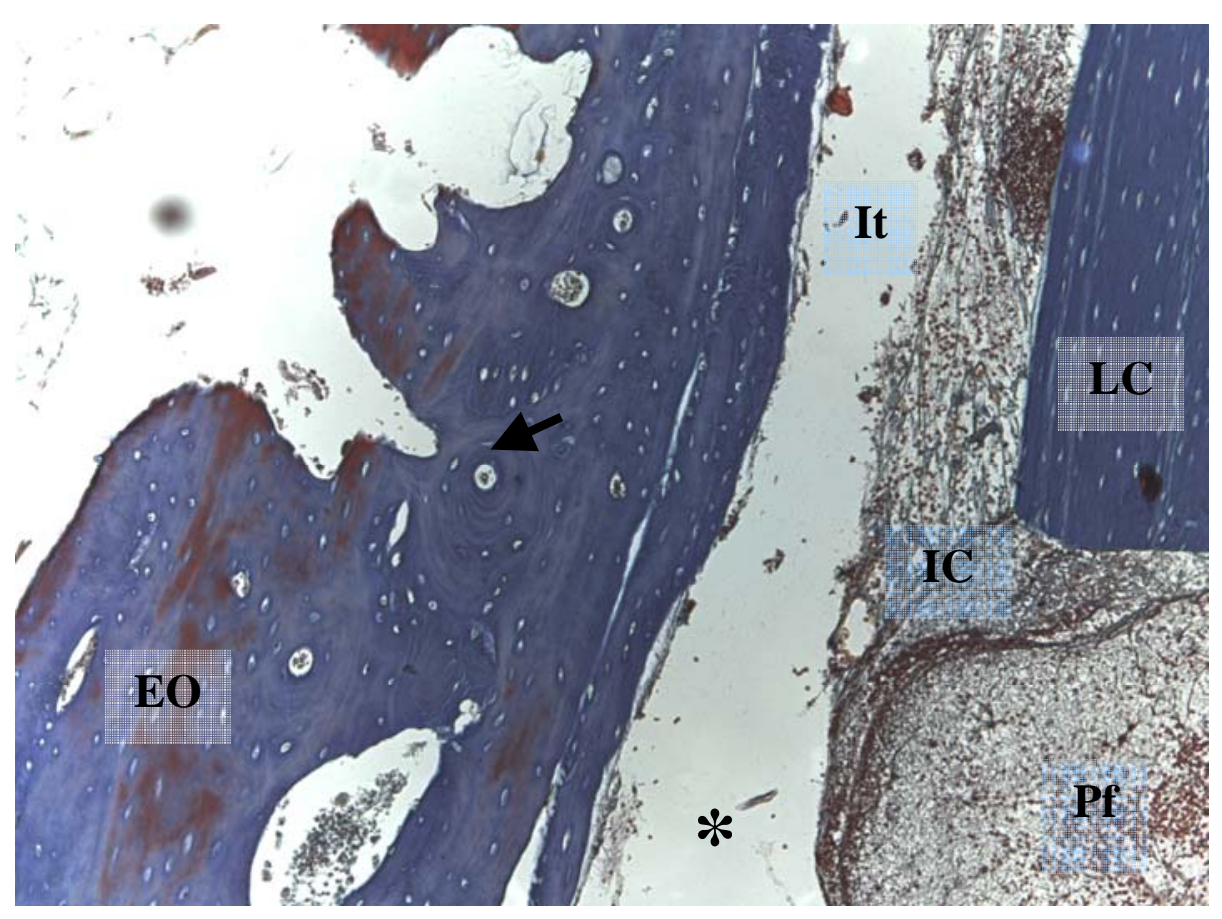

Figura 44 - Fotomicrografia de um sítio com enxerto autógeno. Presença de infiltrado celular (IC) na interface (It) entre enxerto ósseo (EO) e leito receptor (LR) e na perfuração (Pf). Notar (seta) presença de Canal de Harvers no enxerto ósseo. * = separação artefatual. (100x). Tricrômio de Mallory. 
Uma pequena diferença observa-se no período experimental de 5 dias quando se compara com o tempo experimental anterior. A proliferação celular é mais evidente, com pouca presença de células osteoblásticas, porém com sugestiva atividade intensa de diferenciação. Há uma redução de infiltrado celular, início da formação de redes de fibras colágenas. Nesse momento, o periósteo encontra-se mais íntegro, as fibras de colágeno nessa região começam a se organizar (Figura 45).

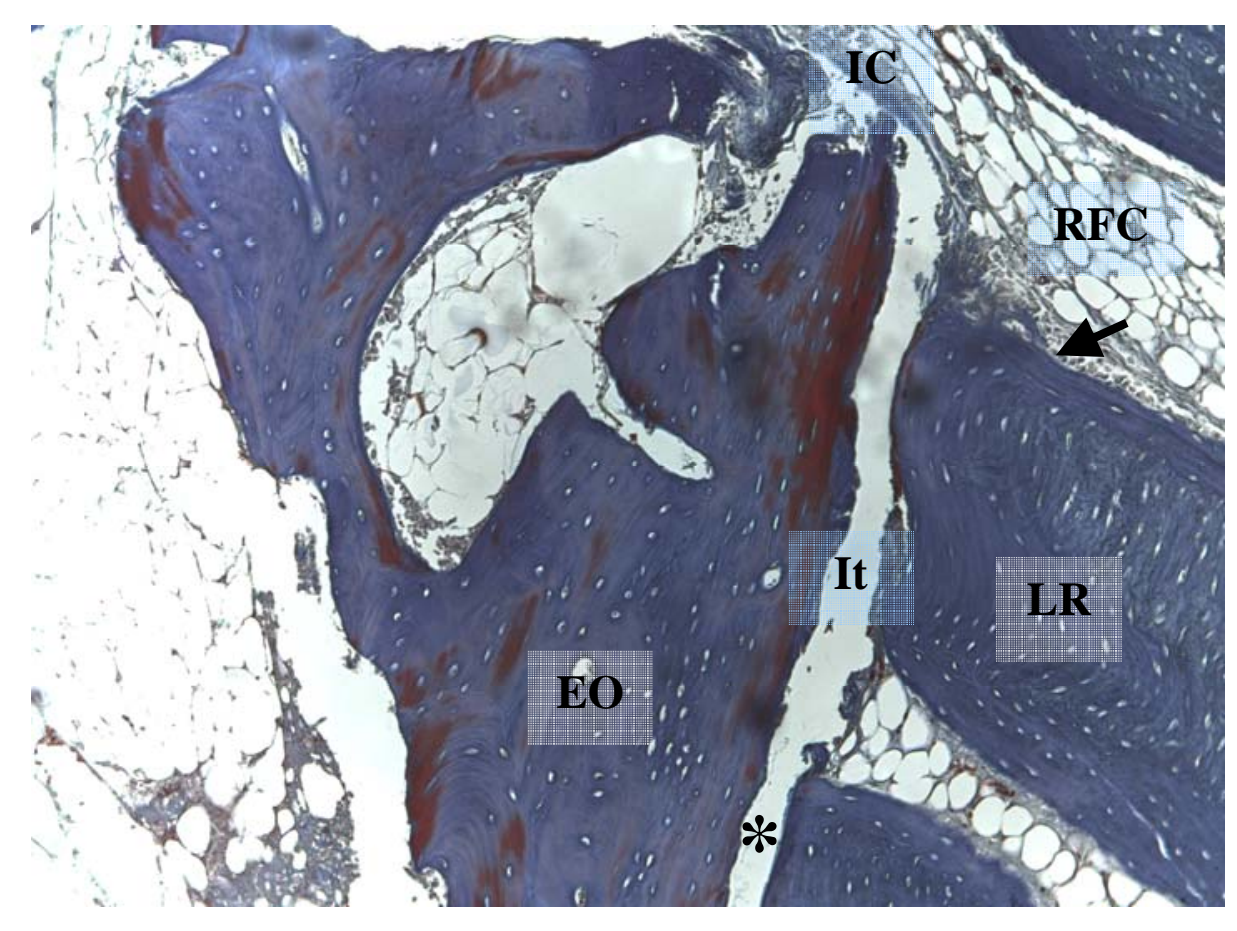

Figura 45 - Fotomicrografia de um sítio com enxerto autógeno. Redução do infiltrado celular (IC), com formação de redes de fibras colágenas (RFC), com início da proliferação celular (seta). EO = Enxerto ósseo. $\mathrm{LR}=$ Leito receptor. $\mathrm{It}=$ interface. $*$ = separação artefatual. (100x). Tricrômio de Mallory. 
No período experimental de 7 dias, o grupo de coelhos com enxerto autógeno obteve maior proliferação celular entre o enxerto e o leito receptor, principalmente nas regiões das perfurações, onde se evidencia a presença de grande quantidade de osteoblastos, tecido adiposo e início da formação de osso jovem. Na interface enxerto/leito receptor pode observar clara deposição de osso novo imaturo em uma matriz extracelular de fibras colágenas frouxamente organizadas unindo o enxerto ao leito receptor, como também nas margens laterais do sítio enxertado logo abaixo do periósteo. Nesse momento evidencia-se a completa regeneração do periósteo (Figura 46).

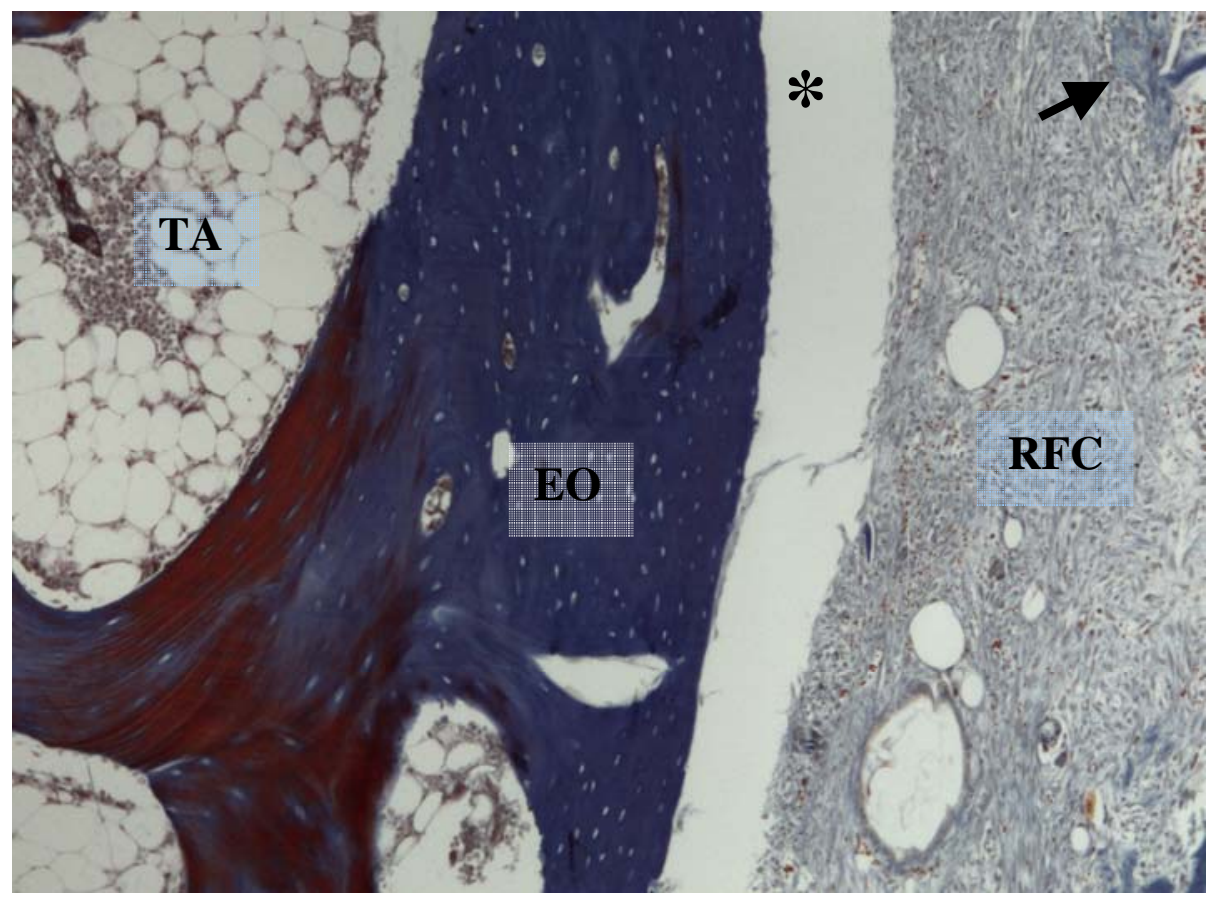

Figura 46 - Fotomicrografia de um sítio com enxerto autógeno. Deposição de osso novo imaturo (seta) em uma matriz extracelular de fibras colágenas frouxamente organizadas (RFC). Presença de tecido adiposo (TA) no interior do enxerto ósseo (EO). * $=$ separação artefatual. (100x). Tricrômio de Mallory. 
No período seguinte, 10 dias, observou-se intensa migração de células osteoblásticas originadas do periósteo e do leito receptor, resultando em uma formação do osso jovem por quase todo leito. A morfologia do enxerto permanece íntegra, com poucas áreas de absorção. Ao lado das perfurações, podemos encontrar a presença de formação de pontes ósseas unindo o enxerto ao leito receptor (Figura 47).

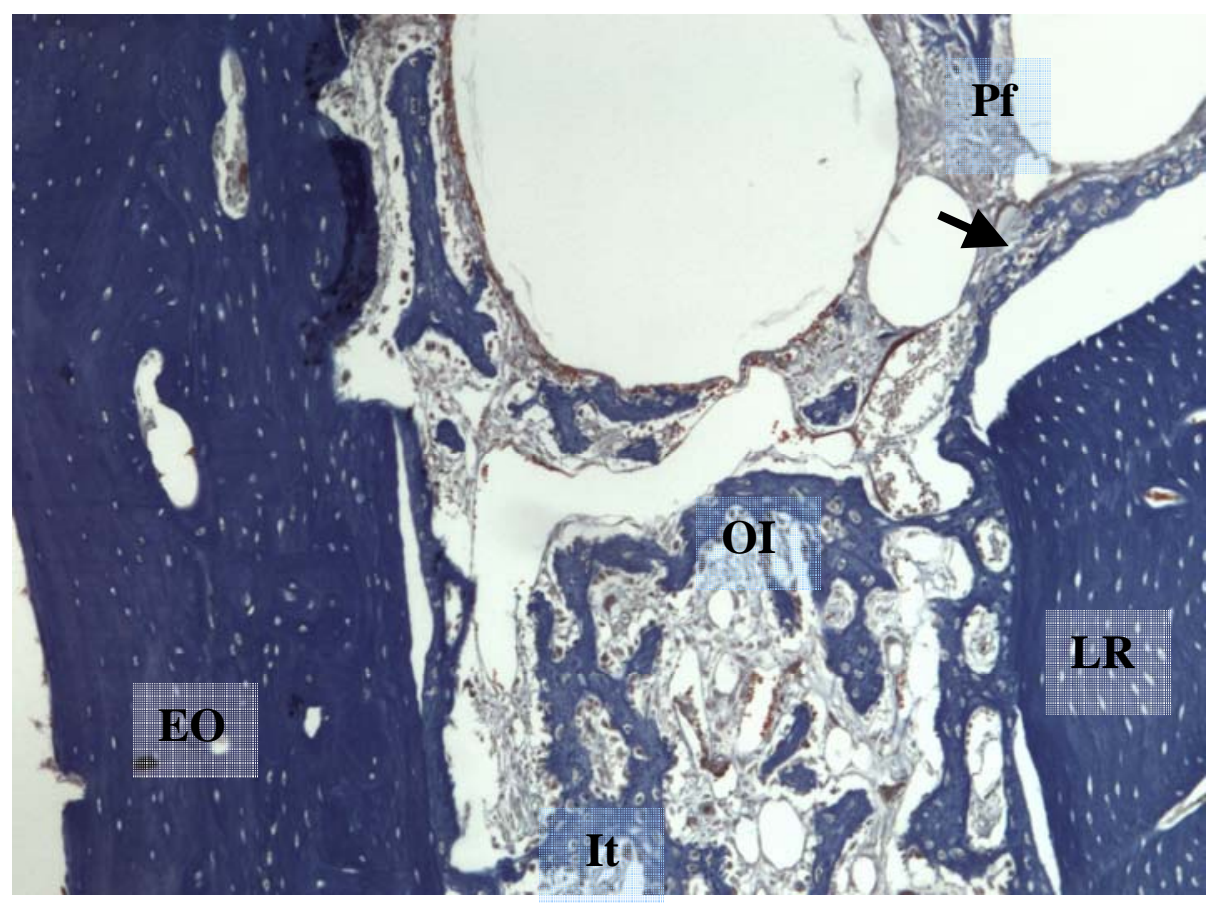

Figura 47 - Fotomicrografia de um sítio com enxerto autógeno. Neoformação de osso imaturo (OI) por quase toda interface (It) entre enxerto ósseo (EO) e leito receptor (LR). Deposição de novo osso imaturo (seta), em uma matriz extracelular de fibras colágenas, localizado próximo a uma área de perfuração (Pf). (100x). Tricrômio de Mallory. 
No período experimental de 20 dias, podemos notar com distinção a incorporação do enxerto em uma forma avançada, com tecido ósseo neoformado mais organizado em continuidade entre o enxerto e o leito. $\mathrm{Na}$ interface e no interior do enxerto observamos presença de células adiposas, há neoformação óssea intensa advinda das perfurações, aumentando ainda mais a união da interface enxerto e leito. Na região periférica abaixo do periósteo encontramos uma grande formação de tecido ósseo, caracterizando a intensa reação do periósteo (Figura 48).

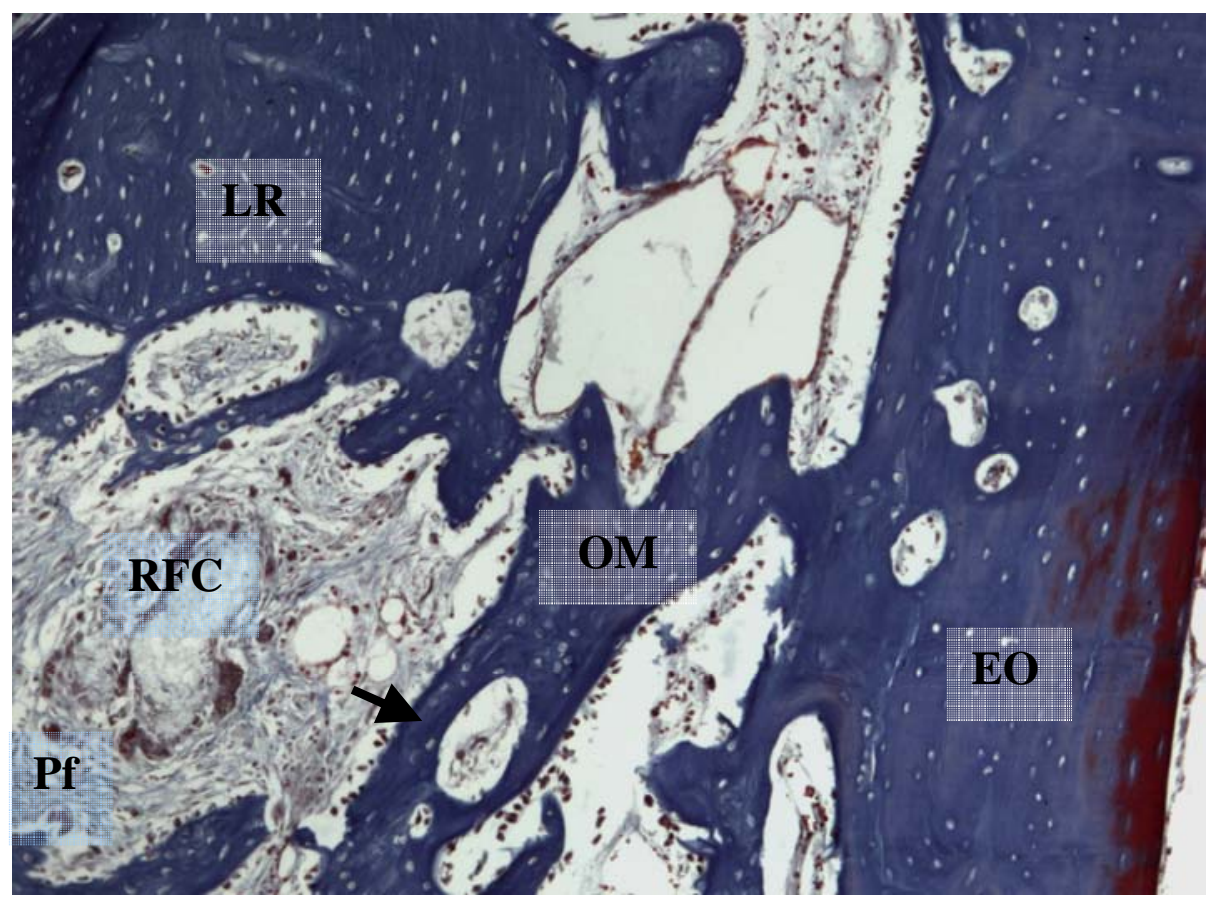

Figura 48 - Fotomicrografia de um sítio com enxerto autógeno. Processo de incorporação do enxerto ósseo (EO) ao leito receptor (LR) bem evidente, caracterizado por pontes de osso maduro (OM) e organizado com lamelas osteônicas unindo essa duas estruturas (seta). Observa-se ainda, presença de matriz extracelular de fibras colágenas (RFC) em perfuração (Pf). (100x). Tricrômio de Mallory. 
No último período experimental, de 60 dias, observou-se pequena absorção na periferia do enxerto. Neste momento, a incorporação do enxerto ao leito receptor estava bem estabelecida através de pontes de osso trabecular maduro já organizado, rico em lamelas concêntricas e canais de Harvers, também visto nas margens laterais do sítio enxertado abaixo do periósteo. Continuamos a notar presença de lacunas de Howship, caracterizando a remodelação, no entanto de uma maneira não muito intensa. No interior do enxerto houve formação óssea bem evidente (Figura 49).

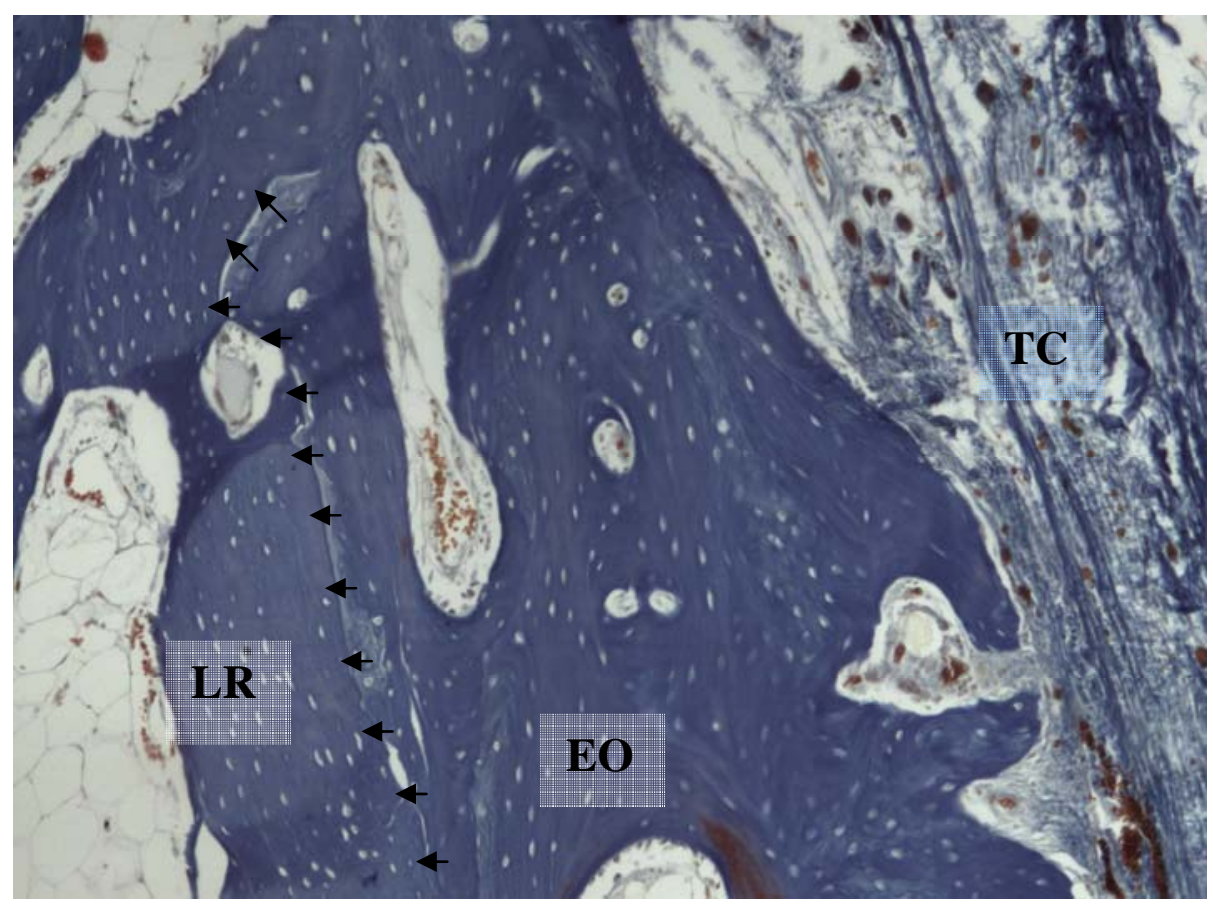

Figura 49 - Fotomicrografia de um sítio com enxerto autógeno. Intensa incorporação do enxerto ósseo (EO) ao leito receptor (LR). Observa-se uma linha divisória entre a intensa incorporação (setas). $\mathrm{TC}=$ Tecido conjuntivo. (100x). Tricrômio de Mallory. 


\subsubsection{Enxerto alógeno}

No tempo experimental inicial (3 dias) para o grupo observou-se pouca diferença em relação ao grupo de enxertos autógenos. Um grande infiltrado celular com maior presença de hemácias, pequena quantidade de proliferação celular e com baixa diferenciação. O periósteo se comportou da mesma maneira como no primeiro grupo, no mesmo tempo experimental. No entanto, a diferença aqui encontrada é a característica do enxerto alógeno: ausência de células osteônicas viáveis no enxerto, havendo apenas a presença de lacunas de osteócitos vazias (ausência de células), que nesse momento apresentam-se preenchidas por hemácias (Figura $50)$.

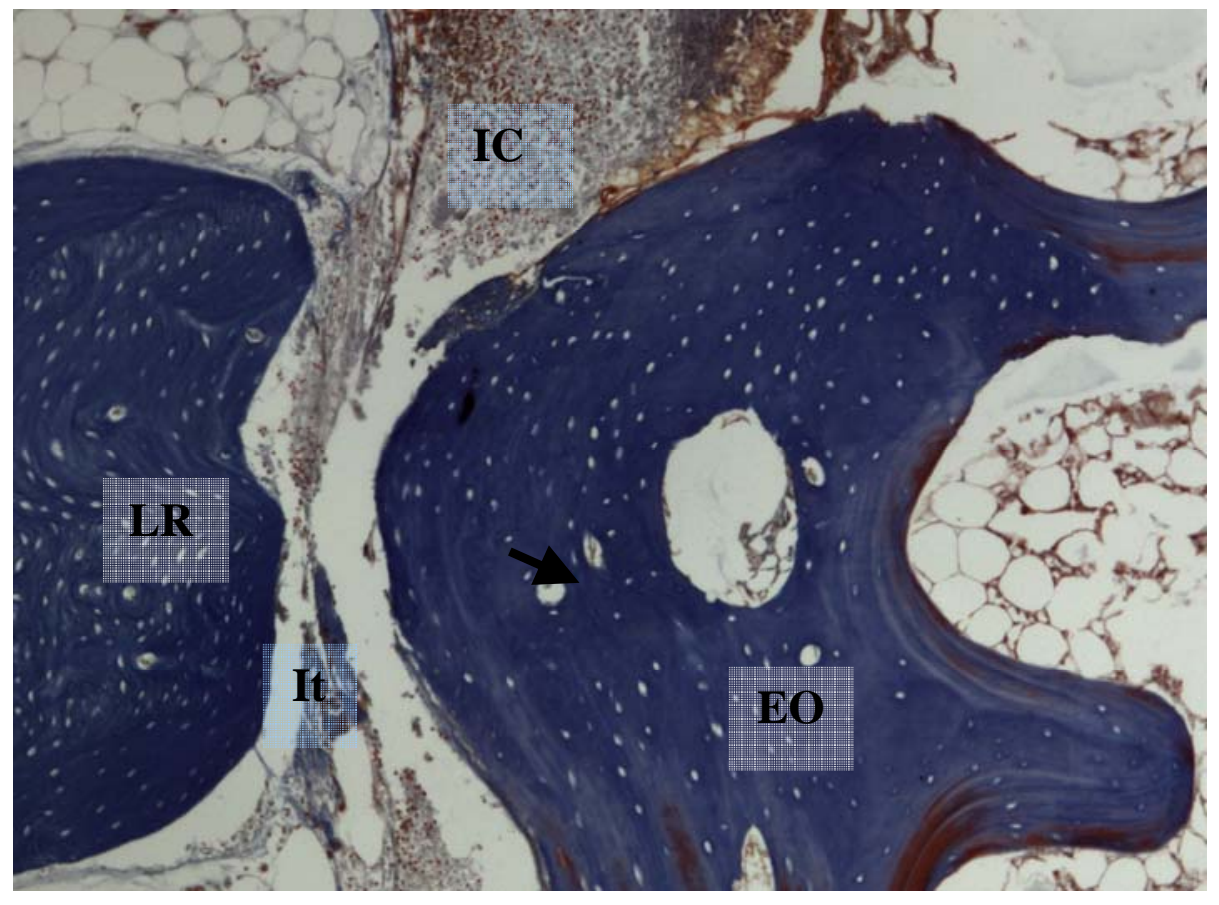

Figura 50 - Fotomicrografia de um sítio com enxerto alógeno. Presença de infiltrado celular (IC) na interface (It) entre o enxerto ósseo (EO) e leito receptor (LR). Notar (seta) presença de lacuna de osteócito vazia. Principal diferença entre o enxerto autógeno. (100x). Tricrômio de Mallory. 
Já no tempo experimental de 5 dias, o infiltrado celular começa a reduzir dando lugar à formação de redes de fibras colágenas frouxamente organizadas, porém de uma maneira menos intensa que encontrada no grupo de coelhos com enxerto autógeno. Neste grupo, foi encontrada também, a presença de fibras colágenas na região periférica do periósteo. $\mathrm{O}$ enxerto ósseo apresentou-se preservado, sem imagens sugestivas de absorção, remodelação ou deposição de osso novo (Figura 51).

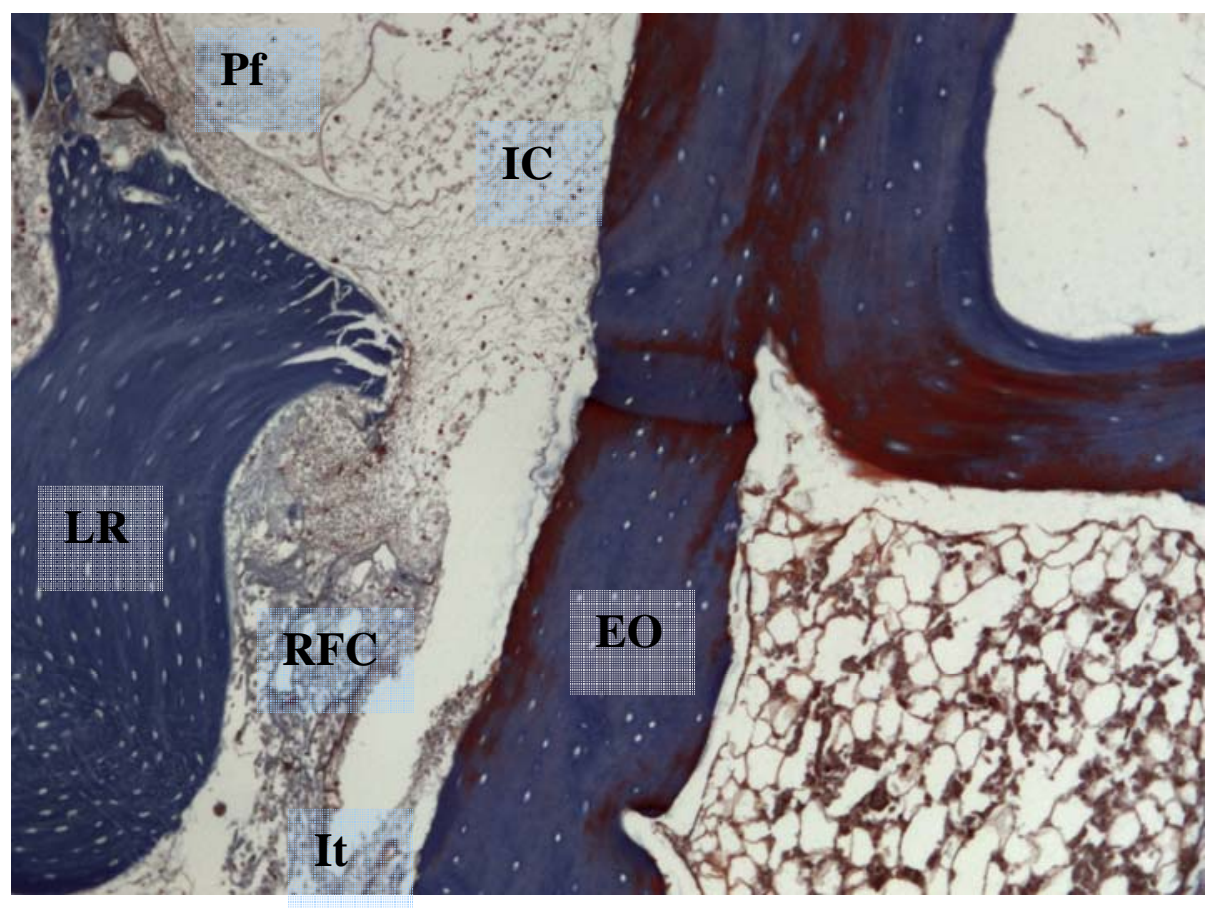

Figura 51 - Fotomicrografia de um sítio com enxerto alógeno. Formação de redes de fibras colágenas frouxamente organizadas (RFC) entre a interface (It) enxerto ósseo (EO) e leito receptor (LR). Pouca presença de infiltrado celular (IC). Pf = Perfuração. (100x). Tricrômio de Mallory. 
No tempo experimental de 7 dias, ocorre uma redução significativa do infiltrado celular, uma melhor organização evidente das redes de fibras colágenas com presença de células pluripotentes, encontradas na interface enxerto e leito receptor. Neste momento, também encontramos uma migração celular da linhagem osteoblástica logo abaixo da região periférica do periósteo. O enxerto continua com altas taxas de preservação de suas estruturas, com poucas imagens que possam sugerir absorção óssea, porém encontramos presença de células osteoclásticas. Ocorre re-povoamento celular no enxerto ósseo neste tempo experimental (Figura 52).

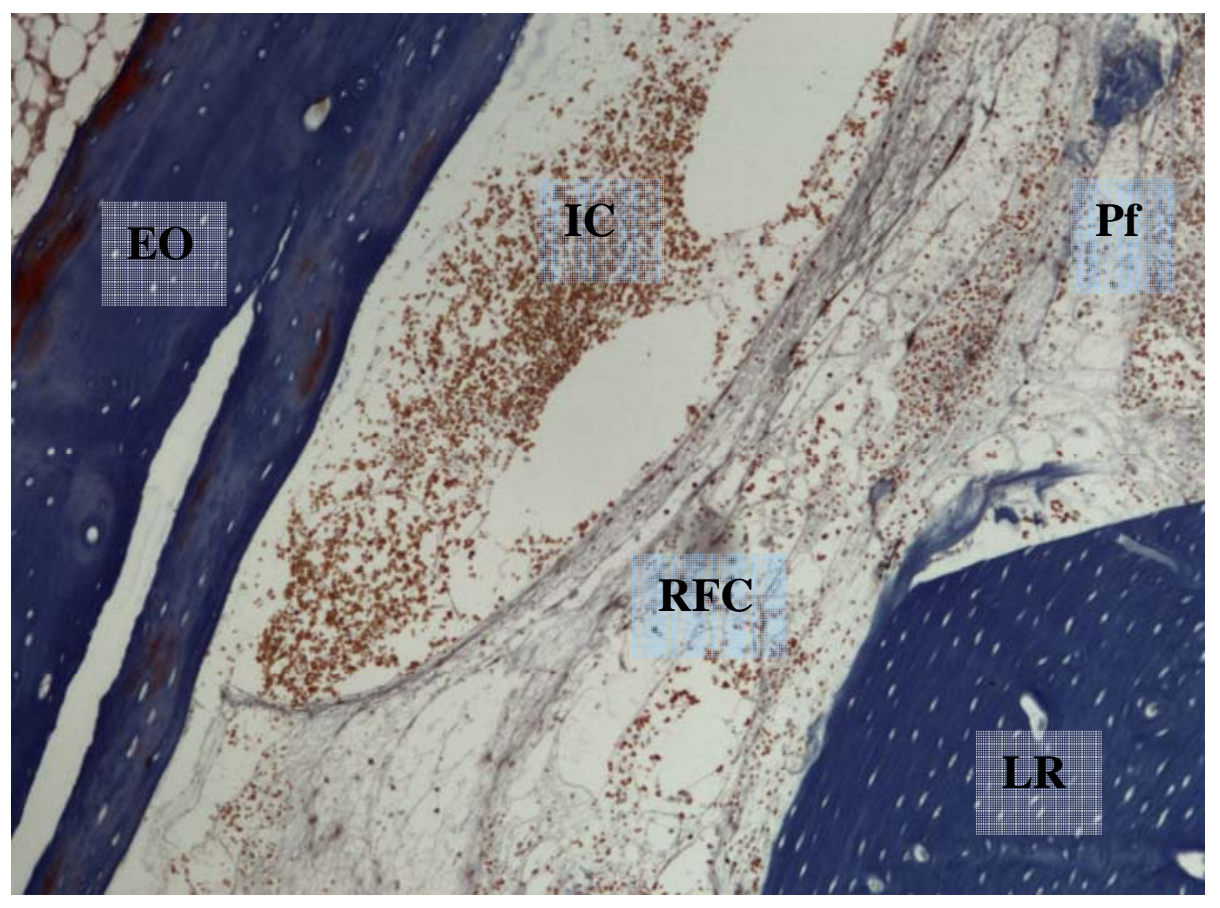

Figura 52 - Fotomicrografia de um sítio com enxerto alógeno. Redução significativa do infiltrado celular (IC) com organização das redes de fibras colágenas (RFC) na interface (It). EO = Enxerto ósseo. $\mathrm{LR}=$ Leito receptor. $\mathrm{Pf}=$ Perfuração. $(100 \mathrm{x})$. Tricrômio de Mallory. 
Após 10 dias, o enxerto continua preservado, a integridade do periósteo já está completa. Há formação de novo tecido ósseo, contudo ainda desorganizado, dividindo espaço com as redes de fibras colágenas. Essa formação óssea ocorre de maneira menos intensa que encontrada no grupo autógeno. Nas perfurações encontra-se novo osso formado em uma freqüência bem menor que no enxerto autógeno. As áreas de absorção são mínimas, porém há maior presença de osteoclasto (Figura 53).

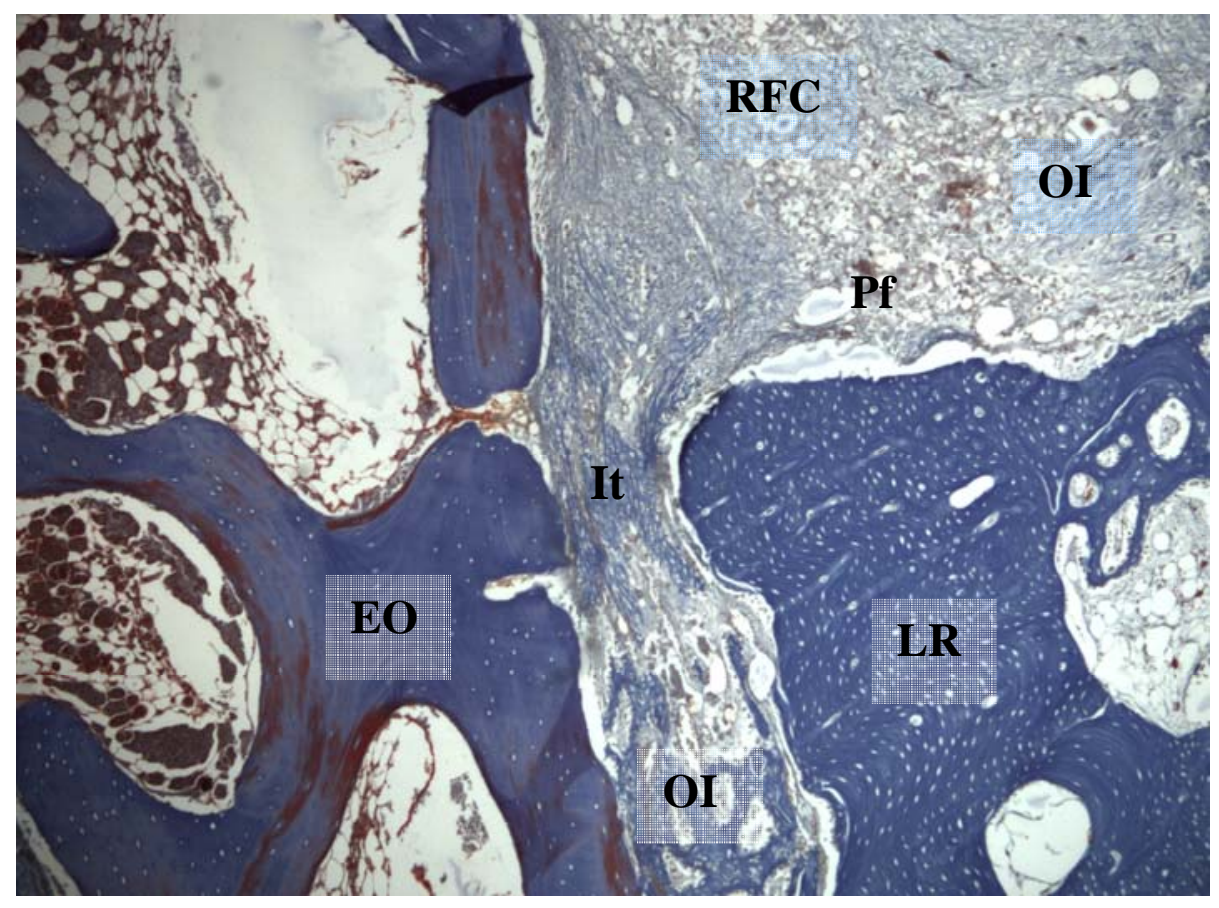

Figura 53 - Fotomicrografia de um sítio com enxerto alógeno. Presença de osso novo imaturo (OI) desorganizado, dividindo espaço com as redes de fibras colágenas frouxamente organizadas (RFC), em áreas da interface (It) e perfuração (Pf). EO = Enxerto ósseo. LR = Leito receptor. (100x). Tricrômio de Mallory 
No tempo experimental de 20 dias encontra-se diferença quanto à reduzida formação de pontes ósseas unindo o enxerto ao leito receptor. A reação do periósteo acontece de forma menos intensa. A remodelação óssea é mais acentuada. No interior do enxerto há pequena formação de novo osso, apesar de ainda ser jovem e desorganizado. Ainda há uma distinção nítida das bordas do enxerto (Figura 54).

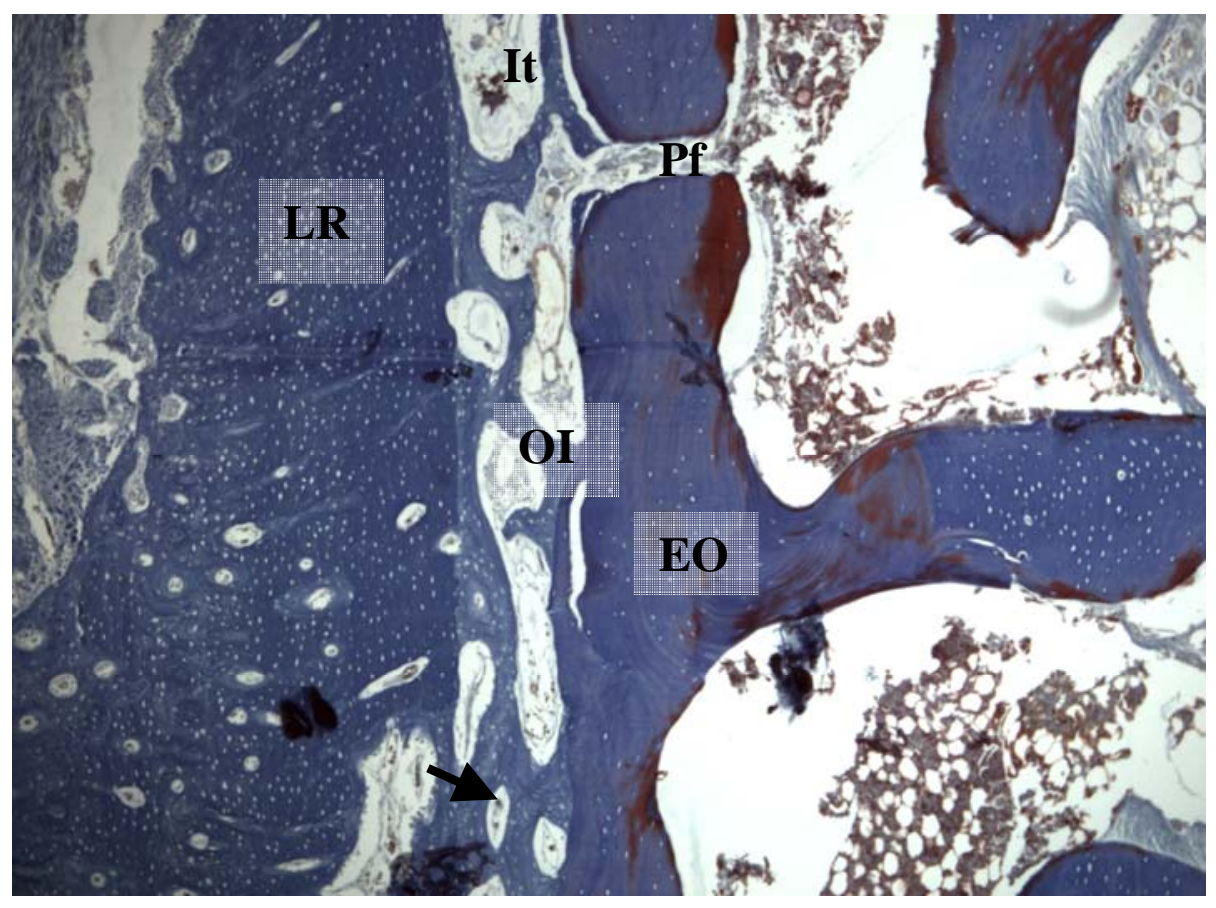

Figura 54 - Fotomicrografia de um sítio com enxerto alógeno. Neoformação de osso imaturo (OI) bem evidente unindo o enxerto ósseo (EO) ao leito receptor (LR). Notar (seta) formação de lamelas concêntricas. $\mathrm{It}=$ interface. $\mathrm{Pf}=$ Perfuração. $(50 \mathrm{x})$. Tricrômio de Mallory. 
No tempo experimental de 60 dias, foi observada uma incorporação do enxerto ósseo, porém em menor intensidade como encontrada no grupo autógeno. A morfologia óssea mostra características de osso maduro e organizado com lamelas concêntricas e ósteons. Há uma intensa remodelação óssea na cortical externa e no interior do enxerto. Neste último há presença de pontes ósseas unindo a cortical externa à cortical interna. Na periferia, sob o periósteo, o osso neoformado encontra-se maduro e organizado, há regiões de união com as bordas do enxerto, entretanto essa união é bem delimitada, pois se observa com nitidez o enxerto da parte óssea neoformada (Figura 55).

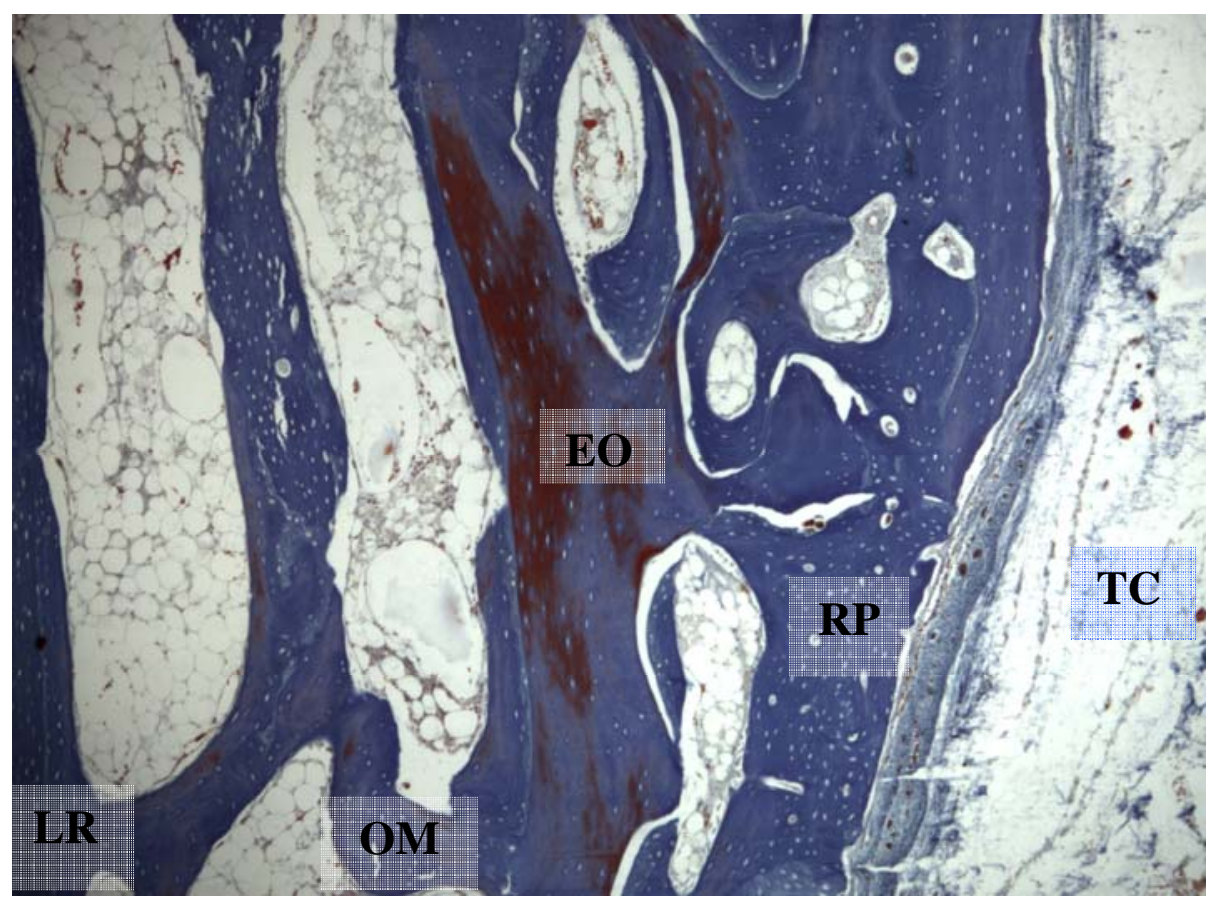

Figura 55 - Fotomicrografia de um sítio com enxerto alógeno. Incorporação do enxerto ósseo (EO) ao leito receptor (LR), caracterizado por pontes de osso maduro $(\mathrm{OM})$. Na margem lateral inferior do enxerto, pode se observar a intensa formação de tecido ósseo maduro, decorrente da reação do periósteo (RP). TC $=$ Tecido conjuntivo. (50x). Tricrômio de Mallory. 


\subsection{Análises imunohistoquímicas}

Os dados das concentrações das proteínas foram colhidos e estão representados no Gráfico 1. As Tabelas de 1 a 7 mostram o tratamento estatístico dos dados para comparação entre os tempos experimentais de cada proteína e para cada grupo (alógeno e autógeno). 

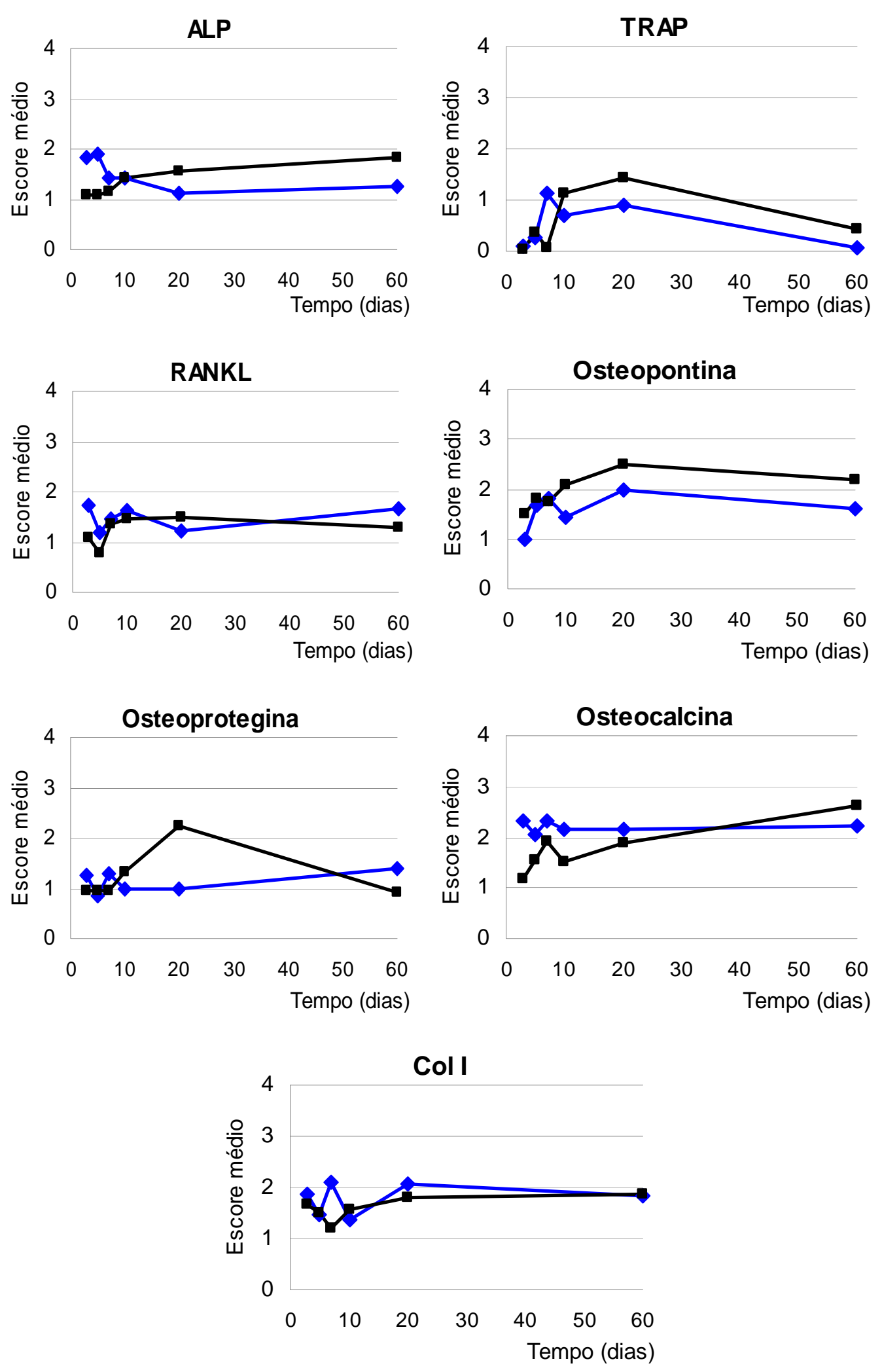

Autógeno Alógeno

Gráfico 1 - Média dos escores das proteínas ALP, TRAP, RANKL, Osteopontina, Osteoprotegina, Osteocalcina e Col I nos seis tempos de avaliação, para os grupos. Autógeno e Alógeno. 
Tabela 1 - Escores da proteína ALP na comparação entre os grupos e tempos.

\begin{tabular}{|c|c|c|c|c|c|c|c|c|}
\hline \multirow{2}{*}{$\begin{array}{c}\text { Tempo } \\
\text { (dias) }\end{array}$} & \multicolumn{4}{|c|}{ Alógeno } & \multicolumn{4}{|c|}{ Autógeno } \\
\hline & média & 10.quartil & mediana & 3o.quartil & média & 10.quartil & mediana & 3o.quartil \\
\hline 3 & $1,8^{a b^{*}}$ & 1,5 & 2,0 & 2,0 & $1,1^{a^{*}}$ & 1,0 & 1,0 & 1,0 \\
\hline 5 & $1,9^{\mathrm{a}}$ & 2,0 & 2,0 & 2,0 & $1,1^{a}$ & 1,0 & 1,0 & 1,0 \\
\hline 7 & $1,4^{\mathrm{ab}}$ & 1,0 & 1,5 & 2,0 & $1,2^{a}$ & 1,0 & 1,0 & 1,5 \\
\hline 10 & $1,4^{\mathrm{ab}}$ & 1,0 & 1,5 & 1,5 & $1,4^{\mathrm{a}}$ & 1,0 & 1,3 & 2,0 \\
\hline 20 & $1,1^{b}$ & 1,0 & 1,0 & 1,2 & $1,6^{a}$ & 1,0 & 1,7 & 2,0 \\
\hline 60 & $1,3^{a b}$ & 1,0 & 1,3 & 1,5 & $1,8^{a}$ & 1,0 & 2,0 & 2,0 \\
\hline
\end{tabular}

* - diferença estatisticamente significante entre leitos $(\mathrm{p}<0,05)$. Tempos com letras iguais, dentro de cada grupo, não possuem diferença estatisticamente significante entre si.

Tabela 2 - Escores da proteína TRAP na comparação entre os grupos e tempos.

\begin{tabular}{|c|c|c|c|c|c|c|c|c|}
\hline \multirow{2}{*}{$\begin{array}{c}\text { Tempo } \\
\text { (dias) }\end{array}$} & \multicolumn{4}{|c|}{ Alógeno } & \multicolumn{4}{|c|}{ Autógeno } \\
\hline & média & 10.quartil & mediana & 3o.quartil & média & 10.quartil & mediana & 3o.quartil \\
\hline 3 & $0,1^{a}$ & 0,0 & 0,0 & 0,2 & $0,0^{a}$ & 0,0 & 0,0 & 0,0 \\
\hline 5 & $0,3^{a b}$ & 0,2 & 0,2 & 0,5 & $0,4^{\mathrm{ab}}$ & 0,0 & 0,5 & 0,5 \\
\hline 7 & $1,1^{b^{*}}$ & 1,0 & 1,3 & 1,3 & $0,1^{a^{*}}$ & 0,0 & 0,0 & 0,2 \\
\hline 10 & $0,7^{\mathrm{ab}}$ & 0,0 & 0,7 & 0,8 & $1,1^{b}$ & 1,0 & 1,0 & 1,2 \\
\hline 20 & $0,9^{a b}$ & 0,5 & 0,8 & 1,3 & $1,4^{b}$ & 1,0 & 1,1 & 1,3 \\
\hline 60 & $0,1^{a}$ & 0,0 & 0,0 & 0,0 & $0,4^{\mathrm{ab}}$ & 0,2 & 0,4 & 0,7 \\
\hline
\end{tabular}

* - Diferença estatisticamente significante entre leitos $(\mathrm{p}<0,05)$. Tempos com letras iguais, dentro de cada grupo, não possuem diferença estatisticamente significante entre si 
Tabela 3 - Escores da proteína RANKL na comparação entre os grupos e tempos.

\begin{tabular}{|c|c|c|c|c|c|c|c|c|}
\hline \multirow{2}{*}{$\begin{array}{c}\text { Tempo } \\
\text { (dias) }\end{array}$} & \multicolumn{4}{|c|}{ Alógeno } & \multicolumn{4}{|c|}{ Autógeno } \\
\hline & média & 10.quartil & mediana & 3o.quartil & média & 10.quartil & mediana & 3o.quartil \\
\hline 3 & 1,7 & 1,0 & 1,0 & 1,0 & 1,1 & 0,7 & 1,0 & 1,3 \\
\hline 5 & 1,2 & 1,0 & 1,0 & 1,5 & 0,8 & 0,7 & 0,8 & 1,0 \\
\hline 7 & 1,4 & 1,0 & 1,5 & 1,8 & 1,4 & 1,0 & 1,3 & 1,8 \\
\hline 10 & 1,6 & 1,3 & 1,8 & 2,0 & 1,5 & 1,0 & 1,4 & 2,0 \\
\hline 20 & 1,2 & 0,5 & 1,4 & 2,0 & 1,5 & 1,0 & 1,3 & 2,0 \\
\hline 60 & 1,7 & 1,0 & 1,8 & 2,0 & 1,3 & 1,0 & 1,1 & 1,5 \\
\hline
\end{tabular}

Não houve diferença estatisticamente significativa entre grupos e entre tempos.

Tabela 4 - Escores da proteína Osteopontina na comparação entre os grupos e tempos.

\begin{tabular}{|c|c|c|c|c|c|c|c|c|}
\hline \multirow{2}{*}{$\begin{array}{c}\text { Tempo } \\
\text { (dias) }\end{array}$} & \multicolumn{4}{|c|}{ Alógeno } & \multicolumn{4}{|c|}{ Autógeno } \\
\hline & média & 10.quartil & mediana & 3o.quartil & média & 10.quartil & mediana & 3o.quartil \\
\hline 3 & 1,0 & 1,0 & 1,0 & 1,0 & 1,5 & 1,0 & 1,0 & 2,0 \\
\hline 5 & 1,7 & 1,3 & 1,8 & 2,0 & 1,8 & 1,5 & 2,0 & 2,0 \\
\hline 7 & 1,8 & 1,5 & 2,0 & 2,0 & 1,8 & 1,5 & 2,0 & 2,0 \\
\hline 10 & 1,4 & 1,0 & 1,0 & 1,7 & 2,1 & 1,5 & 1,8 & 3,0 \\
\hline 20 & 2,0 & 1,5 & 2,0 & 2,5 & 2,5 & 2,0 & 2,8 & 3,0 \\
\hline 60 & 1,6 & 1,2 & 1,5 & 2,0 & 2,2 & 1,7 & 2,0 & 3,0 \\
\hline
\end{tabular}

Não houve diferença estatisticamente significativa entre grupos e entre tempos. 
Tabela 5 - Escores da proteína Osteoprotegerina na comparação entre os grupos e tempos.

\begin{tabular}{|c|c|c|c|c|c|c|c|c|}
\hline \multirow{2}{*}{$\begin{array}{c}\text { Tempo } \\
\text { (dias) }\end{array}$} & \multicolumn{4}{|c|}{ Alógeno } & \multicolumn{4}{|c|}{ Autógeno } \\
\hline & média & 10.quartil & mediana & 3o.quartil & média & 10.quartil & mediana & 3o.quartil \\
\hline 3 & $1,3^{a b}$ & 1,0 & 1,3 & 1,5 & $0,9^{a b}$ & 0,3 & 0,9 & 1,3 \\
\hline 5 & $0,8^{a}$ & 1,0 & 1,0 & 1,0 & $0,9^{a b}$ & 0,7 & 1,0 & 1,2 \\
\hline 7 & $1,3^{a b}$ & 1,0 & 1,5 & 1,5 & $0,9^{a b}$ & 0,5 & 0,8 & 1,5 \\
\hline 10 & $1,0^{a b^{*}}$ & 1,0 & 1,0 & 1,0 & $1,3^{a b^{*}}$ & 1,2 & 1,3 & 1,5 \\
\hline 20 & $1,0^{a b^{\star}}$ & 1,0 & 1,0 & 1,0 & $2,2^{a^{*}}$ & 2,0 & 2,4 & 2,5 \\
\hline 60 & $1,4^{b}$ & 1,2 & 1,3 & 1,5 & $0,9^{b}$ & 0,5 & 1,0 & 1,0 \\
\hline
\end{tabular}

* - diferença estatisticamente significante entre leitos $(\mathrm{p}<0,05)$. Tempos com letras iguais, dentro de cada grupo, não possuem diferença estatisticamente significante entre si.

Tabela 6 - Escores da proteína Osteocalcina na comparação entre os grupos e tempos.

\begin{tabular}{|c|c|c|c|c|c|c|c|c|}
\hline \multirow{2}{*}{$\begin{array}{c}\text { Tempo } \\
\text { (dias) }\end{array}$} & \multicolumn{4}{|c|}{ Alógeno } & \multicolumn{4}{|c|}{ Autógeno } \\
\hline & média & 10.quartil & mediana & 3o.quartil & média & 10.quartil & mediana & 3o.quartil \\
\hline 3 & $2,3^{a^{*}}$ & 2,0 & 2,3 & 3,0 & $1,2^{\mathrm{a}^{*}}$ & 1,0 & 1,0 & 1,0 \\
\hline 5 & $2,1^{a}$ & 1,5 & 2,1 & 2,2 & $1,5^{\mathrm{ab}}$ & 1,1 & 1,6 & 2,0 \\
\hline 7 & $2,3^{a}$ & 2,0 & 2,3 & 2,5 & $1,9^{\mathrm{ab}}$ & 1,5 & 2,0 & 2,0 \\
\hline 10 & $2,2^{a}$ & 2,0 & 2,3 & 2,5 & $1,5^{\mathrm{ab}}$ & 1,0 & 1,1 & 2,0 \\
\hline 20 & $2,1^{a}$ & 1,8 & 2,1 & 2,7 & $1,9^{\mathrm{ab}}$ & 1,5 & 1,9 & 2,0 \\
\hline 60 & $2,2^{a}$ & 2,0 & 2,0 & 2,5 & $2,6^{b}$ & 2,5 & 2,6 & 3,0 \\
\hline
\end{tabular}

* - diferença estatisticamente significante entre leitos $(p<0,05)$. Tempos com letras iguais, dentro de cada grupo, não possuem diferença estatisticamente significante entre si. 
Tabela 7 - Escores da proteína Col I na comparação entre os grupos e tempos.

\begin{tabular}{|c|c|c|c|c|c|c|c|c|}
\hline \multirow{2}{*}{$\begin{array}{c}\text { Tempo } \\
\text { (dias) }\end{array}$} & \multicolumn{4}{|c|}{ Alógeno } & \multicolumn{4}{|c|}{ Autógeno } \\
\hline & média & 10.quartil & mediana & 3o.quartil & média & 10.quartil & mediana & 3o.quartil \\
\hline 3 & 1,9 & 1,0 & 2,0 & 2,7 & 1,7 & 1,0 & 1,5 & 2,5 \\
\hline 5 & 1,5 & 1,0 & 1,3 & 2,0 & 1,5 & 1,0 & 1,5 & 2,0 \\
\hline 7 & 2,1 & 1,2 & 2,3 & 3,0 & 1,2 & 1,0 & 1,1 & 1,5 \\
\hline 10 & 1,4 & 1,0 & 1,1 & 1,5 & 1,6 & 1,0 & 1,8 & 2,0 \\
\hline 20 & 2,1 & 1,5 & 1,9 & 2,5 & 1,8 & 1,5 & 1,7 & 2,0 \\
\hline 60 & 1,8 & 1,5 & 1,8 & 2,0 & 1,9 & 1,0 & 2,0 & 2,2 \\
\hline
\end{tabular}

Não houve diferença estatisticamente significativa entre grupos e entre tempos.

Das proteínas envolvidas na osteogênese (OP, OC, COL I e ALP) apenas a ALP e OC tiveram aumento significante no grupo alógeno comparado com o grupo autógeno aos 3 dias do inicio dos experimentos. A ALP, no grupo alógeno, apresentou-se com uma redução significante de 5 para 20 dias, enquanto que para o grupo autógeno não foi encontrado diferença entre os períodos. Para a OC, foi encontrado um aumento estatisticamente significante do período de 3 para 60 dias para o grupo autógeno, enquanto que no grupo alógeno teve ausência de qualquer variação. A OPN e COL I não apresentaram diferenças entre os grupos e intra-grupos, em relação aos 6 tempos experimentais. Para as proteínas envolvidas com a regulação da indução do processo de osteoclastogênese (OPG, RANKL), a OPG aumentou significantemente no grupo autógeno em relação ao alógeno nos tempos $10 \mathrm{e}$ 20 dias. No grupo alógeno observou um aumento significante do período experimental de 5 para 60, no entanto no grupo autógeno ocorreu uma inversão, uma redução estatisticamente significante de 20 para 60 dias. Nenhuma diferença foi encontrada quanto a RANKL na comparação entre grupos e entre os tempos experimentais relacionados para cada grupo. A TRAP - enzima presente em grandes quantidades na borda corrugada dos osteoclastos, sendo liberada no espaço absortivo entre essa borda e a superfície do osso subjacente durante a absorção óssea - apresentou diferença estatisticamente significante no período experimental de 7 dias entre ambos os grupos, sendo mais intensa para o grupo alógeno. Para este grupo, um aumento significante foi encontrado de 3 para 7 dias, porém de 7 para 60 dias, ocorreu 
uma redução sendo estatisticamente significante. Para o grupo autógeno observou que houve aumentos significantes nos períodos de: 3 para 7 dias, 3 para 20 dias, 7 para 10 dias e 7 para 20 dias.

\subsection{Tomografia computadorizada}

$\mathrm{Na}$ análise tomográfica foi possível identificar o comportamento de ambos os enxertos ósseos "onlay" de calvária em mandíbulas de coelhos, tanto para a variável volume quanto para a densidade, pela subtração dos valores no momento da cirurgia (tempo inicial) com os valores do sacrifício (tempo final), comparados no modo intra-grupos e entre os grupos alógeno e autógeno.

\subsubsection{Volume dos enxertos ósseos}

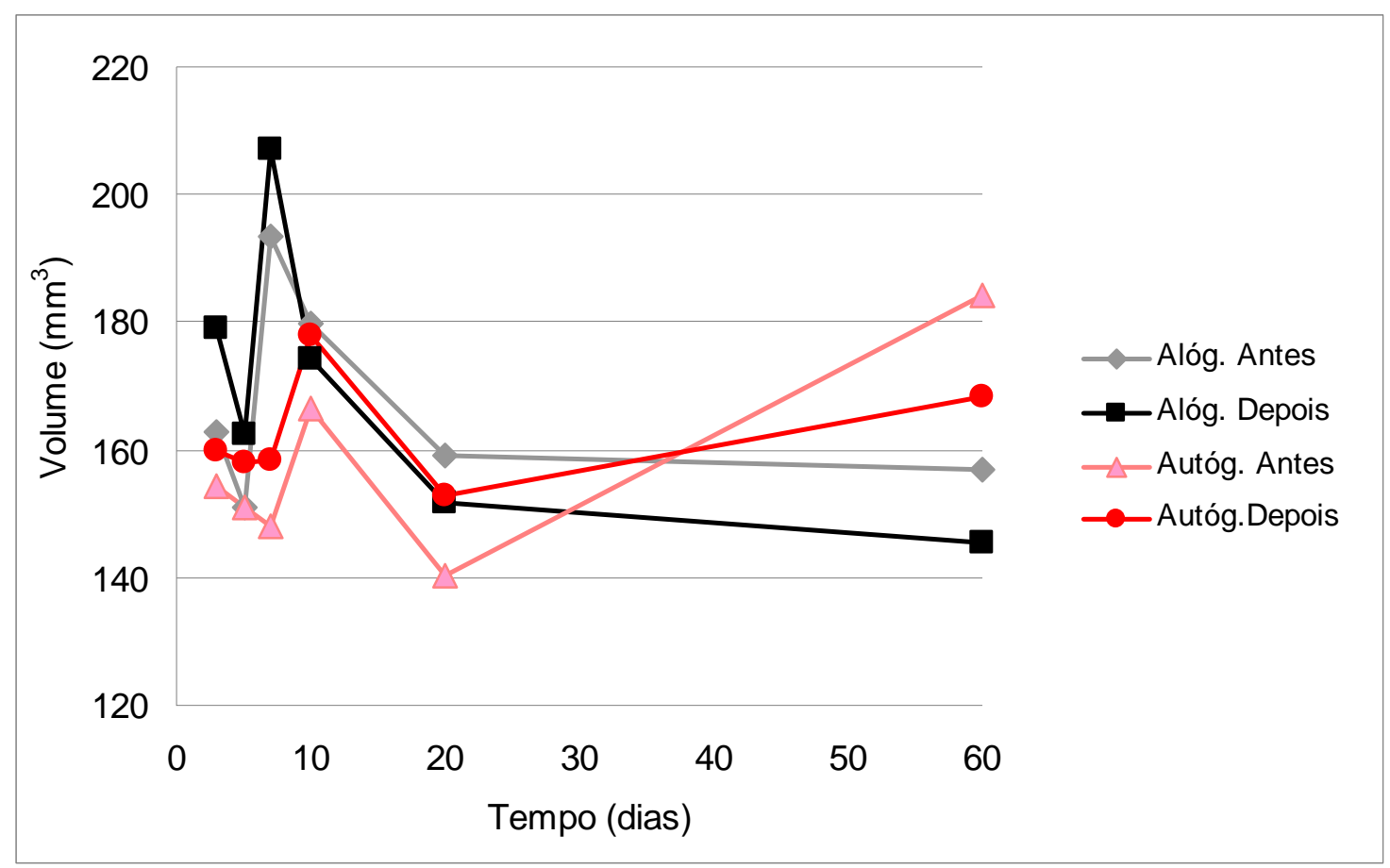

Gráfico 2 - Gráfico da média do volume dos grupos estudados, cirurgia e sacrifício, nos 6 tempos experimentais. 
Tabela 8 - Média e desvio padrão do volume $\left(\mathrm{mm}^{3}\right)$ e resultado da comparação entre os tempos cirurgia e sacrifício.

\begin{tabular}{|c|c|c|c|c|c|}
\hline \multirow{2}{*}{$\begin{array}{l}\text { Tempo } \\
\text { (dias) }\end{array}$} & \multirow{2}{*}{ Leito } & \multicolumn{2}{|c|}{ Cirurgia } & \multicolumn{2}{|c|}{ Sacrifício } \\
\hline & & Média & $\mathrm{dp}$ & média & $\mathrm{dp}$ \\
\hline \multirow{2}{*}{3} & Alógeno & $162,81^{*}$ & 37,60 & $178,87^{*}$ & 32,00 \\
\hline & Autógeno & $154,18^{*}$ & 11,47 & $159,88^{*}$ & 12,57 \\
\hline \multirow{2}{*}{5} & Alógeno & 150,91 & 25,60 & 162,35 & 41,67 \\
\hline & Autógeno & 150,90 & 20,04 & 157,83 & 23,41 \\
\hline \multirow{2}{*}{7} & Alógeno & $193,27^{*}$ & 49,32 & $207,26^{*}$ & 52,77 \\
\hline & Autógeno & 148,12 & 19,93 & 158,27 & 16,11 \\
\hline \multirow{3}{*}{10} & Alógeno & 179,76 & 55,62 & 174,41 & 55,48 \\
\hline & & & & & \\
\hline & Autógeno & 166,43 & 21,82 & 177,84 & 28,50 \\
\hline \multirow{3}{*}{20} & Alógeno & 159,00 & 43,08 & 151,70 & 50,80 \\
\hline & & & & & \\
\hline & Autógeno & 140,26 & 22,22 & 152,99 & 31,84 \\
\hline \multirow{3}{*}{60} & Alógeno & 156,86 & 14,35 & 145,33 & 16,04 \\
\hline & & & & & \\
\hline & Autógeno & 184,25 & 20,96 & 168,43 & 13,79 \\
\hline
\end{tabular}

* - diferença estatisticamente significante entre antes e depois $(\mathrm{p}<0,05)$.

O Gráfico 3 e a Tabela 9 mostram a comparação entre os dois grupos (alógenos versus autógenos) e entre os tempos experimentais (03, 05, 07, 10, 20 e 60 dias). 


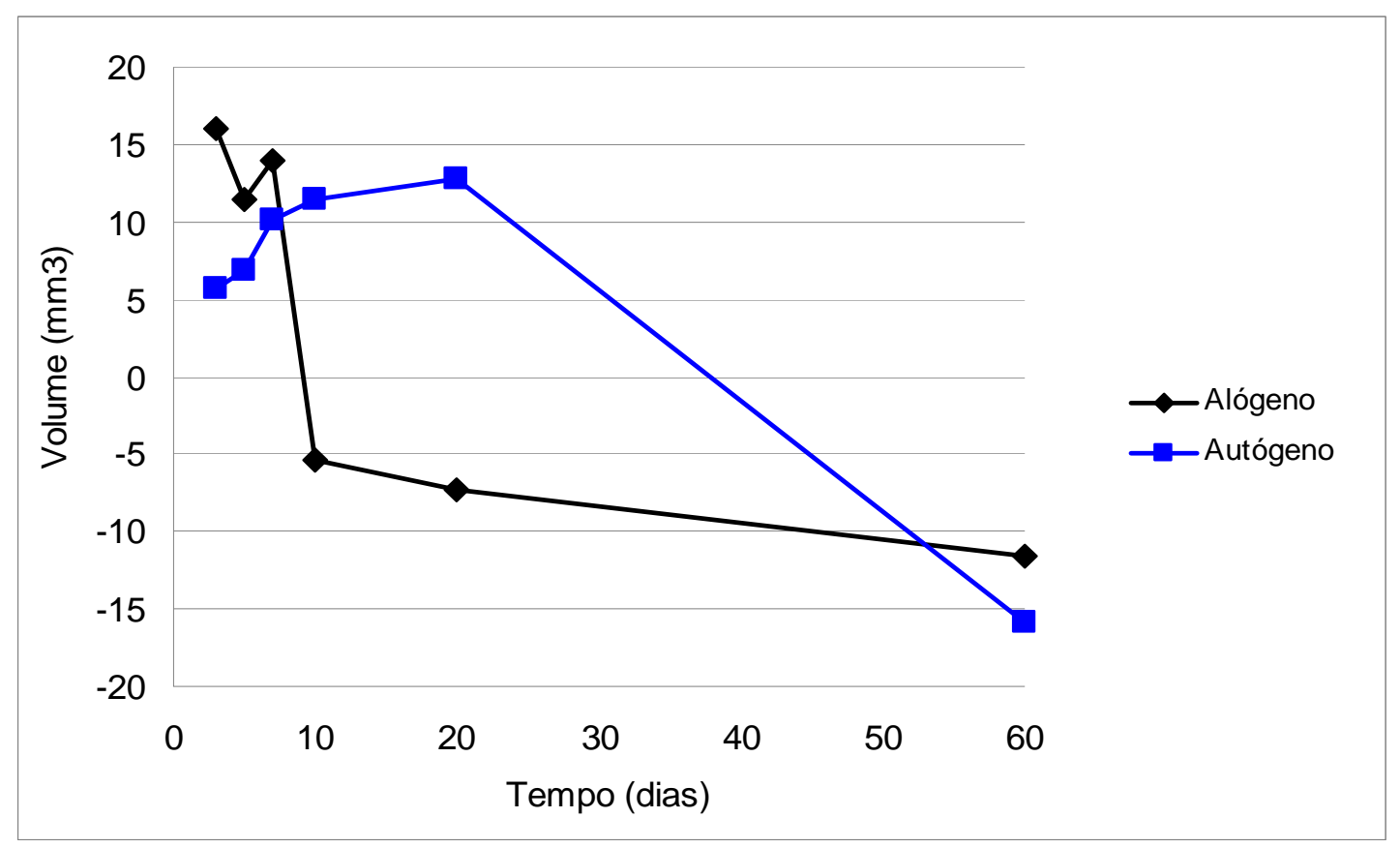

Gráfico 3 - Gráfico da variação do volume (depois - antes) para cada um dos grupos estudados, nos seis tempos de avaliação.

Tabela 9 - Média e desvio padrão da diferença (cirurgia - sacrifício) de volume $\left(\mathrm{mm}^{3}\right)$ e resultado da comparação entre os grupos e os tempos de avaliação.

\begin{tabular}{|c|c|c|c|c|}
\hline \multirow{2}{*}{ Tempo (dias) } & \multicolumn{2}{|c|}{ Alógeno } & \multicolumn{2}{|c|}{ Autógeno } \\
\hline & média & $\mathrm{Dp}$ & média & $\mathrm{dp}$ \\
\hline 3 & $16,07^{\mathrm{ab}}$ & 8,30 & $5,71^{a b}$ & 4,29 \\
\hline 5 & $11,44^{a b}$ & 31,55 & $6,94^{\mathrm{ab}}$ & 16,68 \\
\hline 7 & $13,99^{a}$ & 7,69 & $10,15^{a}$ & 10,84 \\
\hline 10 & $-5,36^{a b}$ & 21,17 & $11,41^{a b}$ & 21,88 \\
\hline 20 & $-7,30^{a b}$ & 32,20 & $12,72^{a b}$ & 25,07 \\
\hline 60 & $-11,52^{b}$ & 15,65 & $-15,82^{b}$ & 15,94 \\
\hline
\end{tabular}

Não houve diferença estatisticamente significativa entre grupos em nenhum tempo. Tempos com a mesma letra não possuem diferença estatisticamente significante entre si. 
Baseado na tabela 8 pode-se observar que os valores obtidos no tempo da cirurgia e do sacrifício houve diferença estatisticamente significante para ambos os grupos no tempo experimental de 3 dias. Já para o tempo experimental de 7 dias encontramos diferença estatisticamente significante apenas para o grupo de enxerto alógeno. Diferentemente, a comparação entre os grupos como observados no gráfico 3 e tabela 9 , não registrou diferenças estatisticamente significantes. Porém há diferenças estatística entre os tempos experimentais intra-grupos. Para o grupo alógeno existe uma diferença significante entre os tempos 7 e 60 dias. Paralelamente, no grupo autógeno a mesma diferença estatística foi encontrada nos mesmos tempos experimentais (entre 7 e 60 dias).

O grupo alógeno apresentou uma redução volumétrica contínua a partir do tempo experimental de 3 dias a 60 dias, exceto no quinto dia onde essa tendência se inverte, apresentando um aumento de volume. Contrariamente, o grupo autógeno exibiu aumento de volume até o vigésimo dia, quando se inicia um processo de redução volumétrica que perdurou até o final dos experimentos.

\subsubsection{Densidade dos enxertos ósseos}

De acordo com os resultados mostrados no gráfico 4 e na tabela 10, a densidade óssea em ambos os grupos (alógeno e autógeno) aumenta após a instalação dos enxertos e atinge grau de significância aos 3 dias pós-operatórios. No grupo alógeno esse aumento persiste até 7 dias. No grupo autógeno, o aumento também continua sendo estatisticamente significante até o tempo experimental de 10 dias.

O gráfico 5 e a tabela 11 revelam que o enxerto autógeno apresentou um aumento da densidade até o décimo dia, mesmo apresentando uma pequena redução no quinto dia. No tempo experimental de 20 dias houve uma redução drástica da densidade seguida de um aumento aos 60 dias. No grupo alógeno, ocorreu um aumento da densidade do terceiro dia para o quinto dia. A partir do sétimo dia, ocorreu uma inversão em relação ao grupo autógeno, caracterizada por uma redução até o décimo dia. No período experimental de 20 dias, a densidade se eleva, reduzindo no período de 60 dias, último tempo experimental. 


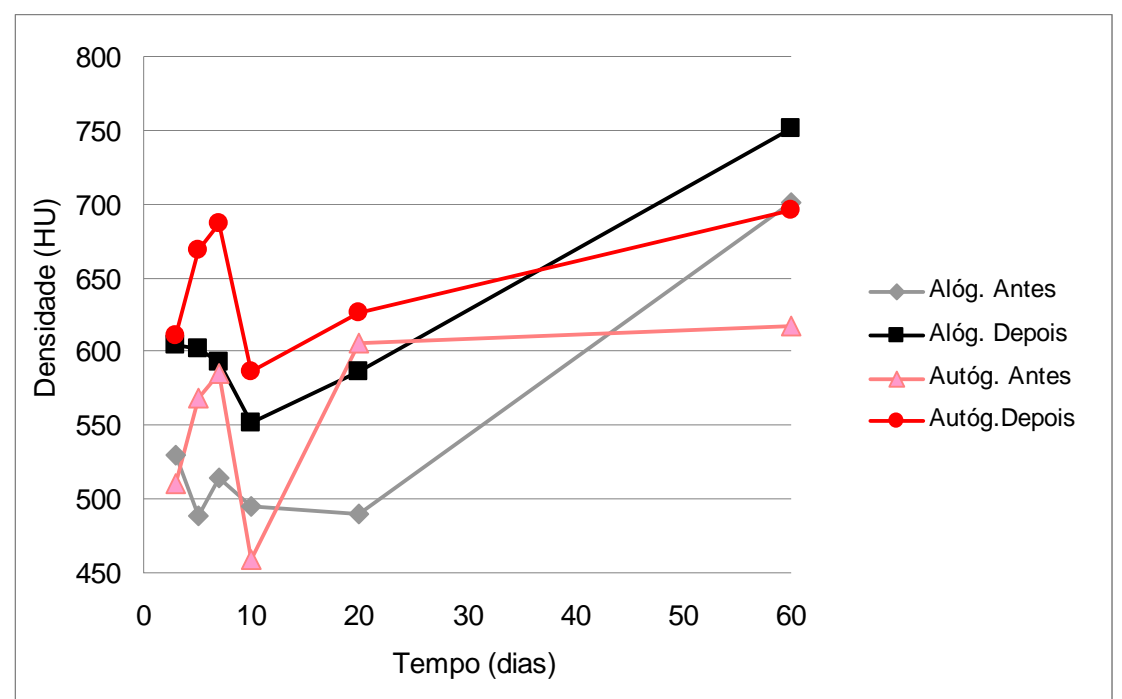

Gráfico 4 - Média da densidade dos grupos estudados, cirurgia e sacrifício, nos seis tempos de avaliação.

Tabela 10 - Média e desvio padrão da densidade (HU) e resultado da comparação entre o tempo da cirurgia e sacrifício.

\begin{tabular}{|c|c|c|c|c|c|}
\hline \multirow{2}{*}{$\begin{array}{c}\text { Tempo } \\
\text { (dias) }\end{array}$} & \multirow{2}{*}{ Leito } & \multicolumn{2}{|c|}{ Cirurgia } & \multicolumn{2}{|c|}{ Sacrifício } \\
\hline & & média & $\mathrm{Dp}$ & média & $\mathrm{dp}$ \\
\hline \multirow{2}{*}{3} & Alógeno & $529,42^{*}$ & 101,56 & $603,78^{*}$ & 79,16 \\
\hline & Autógeno & $510,23^{*}$ & 94,51 & $611,28^{*}$ & 129,84 \\
\hline \multirow{2}{*}{5} & Alógeno & 488,30 & 114,04 & 602,08 & 137,12 \\
\hline & Autógeno & 568,56 & 113,88 & 669,25 & 62,87 \\
\hline \multirow{2}{*}{7} & Alógeno & $513,73^{*}$ & 138,92 & $592,87^{*}$ & 127,36 \\
\hline & Autógeno & 584,70 & 217,22 & 686,85 & 160,13 \\
\hline \multirow{2}{*}{10} & Alógeno & 494,78 & 96,97 & 552,18 & 62,22 \\
\hline & Autógeno & $459,65^{*}$ & 69,43 & $585,96^{\star}$ & 67,65 \\
\hline \multirow{2}{*}{20} & Alógeno & 490,47 & 97,54 & 586,95 & 169,94 \\
\hline & Autógeno & 605,37 & 192,92 & 625,83 & 203,87 \\
\hline \multirow{2}{*}{60} & Alógeno & 700,43 & 65,35 & 751,35 & 104,87 \\
\hline & Autógeno & 617,39 & 81,42 & 695,68 & 140,91 \\
\hline
\end{tabular}




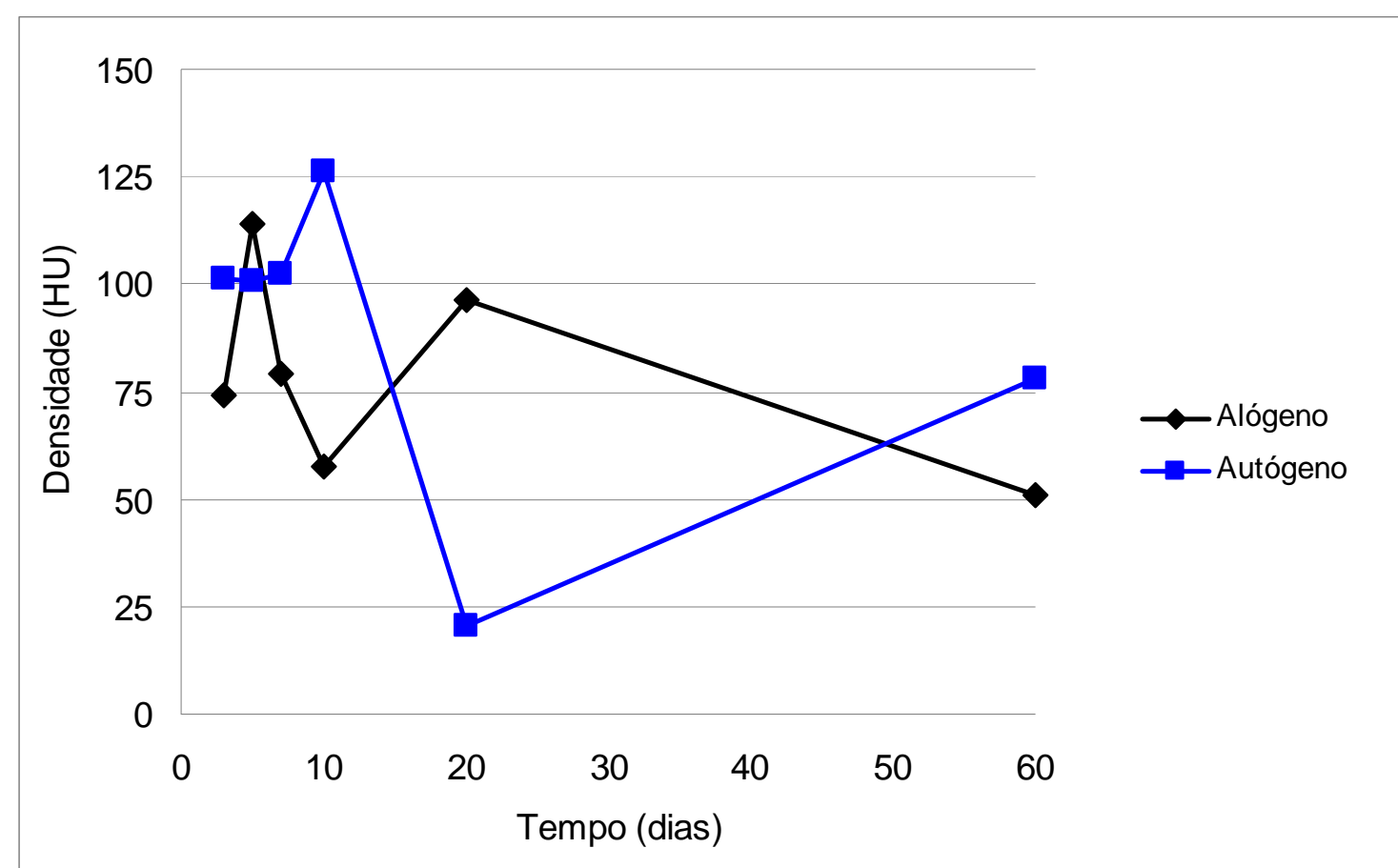

Gráfico 5 - Gráfico da variação da densidade (cirurgia - sacrifício) para cada um dos grupos estudados, nos seis tempos de avaliação.

Tabela 11 - Média e desvio padrão da diferença (cirurgia - sacrifício) de densidade (HU) e resultado da comparação entre os grupos e os tempos de avaliação.

\begin{tabular}{cccccc}
\hline \multirow{2}{*}{ Tempo (dias) } & \multicolumn{2}{c}{ Alógeno } & & \multicolumn{2}{c}{ Autógeno } \\
\cline { 2 - 3 } \cline { 5 - 6 } \cline { 5 - 6 } & média & Dp & & Média & dp \\
\hline 5 & 74,36 & 53,20 & & 101,05 & 91,61 \\
7 & 113,78 & 130,35 & & 100,69 & 124,33 \\
10 & 79,13 & 62,18 & & 102,15 & 98,04 \\
20 & 57,40 & 62,46 & & 126,31 & 87,62 \\
60 & 96,48 & 138,33 & & 20,47 & 329,66 \\
& 50,92 & 112,91 & & 78,30 & 91,43
\end{tabular}

Não houve diferença estatisticamente significativa entre grupos e entre tempos. 
6. DISCUSSÃO 


\section{DISCUSSÃO}

O uso de procedimentos para ganho ósseo para posterior reabilitação com implantes dentários através de enxerto ósseo é amplamente utilizado (BARONE et al, 2009). Nas últimas décadas o enxerto alógeno tem despertado o interesse de clínicos e pesquisadores como uma alternativa promissora para esses procedimentos. Historicamente, o primeiro enxerto com osso alógeno foi realizado em 1880 por um cirurgião escocês que reconstruiu com sucesso o úmero infectado de um menino de 4 anos de idade com enxerto obtido da tíbia de outro menino com raquitismo (De BOER, 1968). Mais recentemente, o enxerto ósseo alógeno fresco congelado tem tido sucesso há 20 anos em cirurgias ortopédicas para tratamento reconstrutivos de membros após ressecção de tumores, para preenchimento de cavidades no tratamento de cistos ósseos, redução de fraturas e uma variedade de outras condições (JOHNSON, 1980). O transplante de enxertos ósseos alógenos de osso longos continuou e teve sua expansão acelerada a partir da década de 90 (TOMFORD, 2000). Nesse período o emprego do enxerto alógeno se expandiu do campo da ortopedia para a odontologia e tem sido utilizado para a reconstrução de sítios afetados pela a ablação de tumores mandibulares e para correção de contornos mandibulares para instalação de implantes (JOHNSON, 1980). Chaushu et al (2009) avaliaram a taxa de sucesso implantes dentários colocados simultaneamente com levantamento do soalho do seio maxilar com enxerto alógeno em bloco. Eles concluíram que o enxerto alógeno possui potencial como material para enxerto em procedimentos com essa finalidade. O mesmo grupo de pesquisa avaliou o resultado da utilização do enxerto alógeno para aumento ósseo da região posterior de mandíbula atrófica e 6 meses após instalaram implantes dentários. Os autores concluíram que implantes dentários instalados em osso alógeno devem ser considerados um tratamento alternativo viável ao osso autógeno (NISSAN et al, 2009). Entretanto, ainda persistem dúvidas quanto ao comportamento biológico do material alógeno no curto, médio e longo prazos após sua implantação. O objetivo do presente estudo foi investigar comparativamente o comportamento do enxerto alógeno frente ao enxerto autógeno, ambos instalados "onlay" em mandíbula de coelhos, utilizando tomografia, histologia e imunohistoquímica.

Os dados tomográficos no grupo autógeno revelaram um aumento em volume até o vigésimo dia, seguido de redução até o final dos experimentos. O grupo alógeno exibiu uma curva contínua de perda de volume desde os tempos remotos da instalação até os 60 dias. Ambos os tipos de enxertos experimentaram significante reabsorção entre os tempos 7 dias e 
60 dias. Embora não houvesse significância estatística entre os grupos quanto aos valores de volume, os achados de marcações protéicas exibiram variação de escores para ALP; OC; OPG; e TRAP, enquanto COL-1; RANKL; e OPN não variaram, sugerindo que essas últimas não interferiram no processo de remodelação óssea avaliado neste estudo. No que se refere à concentração de ALP, houve um aumento significante nos grupos alógeno e autógeno aos 3 dias e permaneceu estável nos demais tempos. Em ambos os grupos ocorreu um aumento de volume aos 3 dias, portanto, a ALP - considerada marcador precoce da diferenciação osteoblástica (BELLOWS et al. 1991; LIU et al. 1996) - pode ter contribuído para o aumento intra-grupos de volumes ósseos verificado nesse período. Paralelamente, a OC é uma proteína da matriz óssea predominantemente sintetizada por osteoblasto (BRONCKERS et al. 1985) e tem papel importante na neoformação e mineralização óssea (GARNERO \& DELMAS, 1998). A OC está associada ao "turnover" ósseo quando reabsorção e formação estão ocorrendo simultaneamente (DUCY et al. 1996). Em nosso estudo, a OC exibiu um pico de concentração aos 3 dias no grupo alógeno comparado ao grupo autógeno (com diferença estatística) e sustentou níveis mais altos até o vigésimo dia (sem diferença estatística). Esse dado pode explicar os resultados histológicos de maior intensidade de reabsorção no grupo alógeno a partir de 10 dias até o final dos experimentos. Por outro lado, as marcações de OPG foram estatisticamente maiores no grupo autógeno comparado aos valores do grupo alógeno. A OPG atua como receptor inibitório para RANKL, pois bloqueia a interação RANK/RANKL, inibindo o estágio terminal de diferenciação osteoclástica e, assim, resultando em diminuição da reabsorção óssea (HOFBAUER, 2006; BAUD’HUIN et al., 2007). Adicionalmente, a marcação da TRAP foi mais intensa no sétimo dia para o grupo alógeno, o que pode justificar a redução volumétrica acentuada ocorrida a partir desse período, considerando que esta proteína está envolvida no processo de reabsorção óssea. Nossos dados corroboram com os de Winslow et al (2006), que afirmaram que as células TRAP positivas aparecem a partir do quinto dia após a enxertia. Assim, os resultados imunohistoquímicos juntos podem explicar a tendência de manutenção de volume dos enxertos autógenos em relação aos alógenos nesse estudo. As características histológicas encontradas para o grupo autógeno corroboram com os achados de Azem (2002), que analisou a revascularização do enxerto ósseo autógeno em bloco associado ou não a membrana de PTFE. O autor observou que após 3 dias o enxerto sem a barreira mostrou-se difuso com presença de brotos vasculares provenientes do leito. Após 7 dias, a revascularização ocorreu a partir de vasos originários do leito e do tecido conjuntivo circundante penetrando através da periferia do enxerto. No $14^{\mathrm{o}}$ dia, o grupo com enxerto ósseo autógeno mostrou penetração de 
vasos na periferia do enxerto, alcançando variáveis extensões no interior do mesmo. Aos 21 dias, a penetração vascular pôde ser observada em toda a extensão do enxerto e principalmente notada nas regiões próximas à perfuração.

A análise da densidade não mostrou diferenças estatísticas entre o grupo alógeno e autógeno, embora neste último houvesse uma tendência de valores Hounsfield mais elevada. No grupo autógeno houve um aumento de densidade até o décimo dia com uma pequena redução no quinto dia, sem significância estatística. A partir do vigésimo dia ocorre uma redução acentuada da densidade até o último período experimental. A provável explicação para esses efeitos estaria nos achados histológicos, pois há uma grande formação de novo osso nos períodos de até 20 dias caracterizada por maturação e mineralização óssea. Após esse período evidencia-se uma tendência acentuada para remodelação óssea, que é mais evidenciada no período de 60 dias. Para o grupo alógeno, encontramos variações bem menos intensas que no grupo autógeno. No período experimental de 3 e 5 dias, houve um aumento da densidade, pois nesse momento há evidências histológicas de diferenciação celular. A partir do sétimo dia ocorre uma redução até o último período (60 dias). Entretanto, no período de 20 dias houve ocorreu um intenso processo de maturação óssea, corroborado pela a análise histológica. Essa redução contínua da densidade pode ser explicada através dos achados de Intini et al. (2008), que identificaram desmineralização incompleta e parcial do enxerto alógeno detectada por análise micro-tomográfica. Outros autores (KLUGER et al, 2003) especulam que o osso congelado (osso alógeno) seria mais resistente à absorção, entretanto menos osteogênico.

No presente estudo, o osso autógeno foi incorporado e mostrou-se com vitalidade nos períodos tardios, fato este comprovado histológica e imunohistoquimicamente, o que não foi observado com o osso alógeno. A formação óssea é conduzida por células sobreviventes do enxerto e pela habilidade da matriz óssea em induzir a diferenciação de células osteoprogenitoras na área receptora. Embora o enxerto e o leito tenham contribuições individuais para o processo, é a soma dessas interações que determina o sucesso e falência do enxerto. Esta importante consideração talvez possa explicar os achados no grupo autógeno, aos 60 dias, com grande parte das regiões ocupadas por novos osteócitos viáveis, numeroso canais vasculares com conteúdo celular e regiões de neoformação óssea. Diferentemente do grupo alógeno, que exibia predominância de lacunas vazias de osteócitos e pouca vascularização. O tecido ósseo mineralizado contendo áreas com lacunas de osteócitos vazias é definida como enxerto ósseo não-vital, mesmo que haja formação de osso maduro ao redor de partículas do enxerto (KEITH et al, 2006; SOHN et al. 2009). 
7. CONCLUSÃO 


\section{CONCLUSÃO}

Com base nos resultados observados a partir das condições metodológicas experimentais deste trabalho, foi possível concluir que:

Enxertos autógenos e alógenos exibiram padrões de preservação de volume e densidade similares;

Os dados histológicos mostram que a remodelação óssea no grupo alógeno ocorreu de modo mais intenso que no grupo autógeno;

A avaliação por microscopia de luz mostra que a incorporação do osso autógeno ao leito receptor foi mais eficiente que no grupo alógeno;

No grupo alógeno os resultados de imunohistoquímica demonstraram um quadro típico de intensa remodelação dos enxertos. 


\section{REFERÊNCIAS BIBLIOGRÁFICAS}

$\mathrm{AHO}$, A. J. et al. Immune responses and clinical outcome of massive human osteoarticular allografts. Clin Orthop Res, v. 196, 1998.

AJZEN, S.A. et al. Análise por tomografia computadorizada do enxerto autógeno na cirurgia de "sinus lifting". Radiologia Brasileira, v. 38, n. 1, p. 25-31, Rio de Janeiro, JanFev.2005.

ALBERIUS, P. et al. Onlay bone graft behavior after marrow exposure of the recipient rat skull bone. Scandinavian Journal Plastic Reconsttuctive Hand Surgery, v. 30, p. 257-266, 1996.

ALBERIUS, P., GORDH, M. Osteopontin and bone sialoprotein distribution at the bone graft recipient site. Archives Otolaryngology Head Neck Surgery, v. 124, p.1382-1386. 1998.

AMERICAN ACADEMY OF PERIODONTOLOGY. Tissue banking of bone allografts used in periodontal regeneration. Journal of Periodontology, v. 72, p. 834-838, 2001.

ANITUA, E. et al. New insights into and novel applications for platelet-rich plasma fibrin therapies. Trends in Biotechnology, v. 24, n. 5, p. 227-234, Amsterdam, Maio. 2006.

AZEM, A.C. Revascularização de enxerto ósseo autógeno em bloco associado ou não a membrana de PTFE-e. 2002. 57 p. Dissertação (Mestrado) - Universidade de São Paulo. Faculdade de Odontologia. São Paulo.

BARONE, A. et al. Deep-frozen allogeneic onlay bone grafts for reconstruction of atrophic maxillary alveolar ridges: a preliminary study. Journal of Oral and Maxillofacial Surgery, v. 67, p. 1300-1306, 2009.

BAUD'HUIN, M. et al. RANKL, RANK, osetoprotegerin: key partners of osteoimunology and vascular diseases. Cell Mol Life Sci, v.64, p. 2334-2350,2007.

BELLOWS, C. G., AUBIN, J. E., HEERSCHE, J. N. M. Initiation and progression of mineralization of bone nodules formed in vitro: the role of alkaline phosphatase and organic phosphate. Bone mineralizatio; v. 14, p. 27-40, 1991. 
BOYNE, P.J. Introduction of bone repair by various bone grafting materials. Hard tissue growth repair and mineralization. Ciba Found. Symp. 11:121-141. 1973.

BOYNE, P.J. Studies of the surgical application of osteoconductive and osteoinductive materials. Tissue Engineering: Applications in Maxillofacial Surgery and Periodontics. Quitessence Publishing CO., Samuel E. Lynch; Robert J. Genco and Robert E. Marx . Eds., Illinois, 1999.

BRONCKERS, A. L. et al. Immunolocalization of gamma-carboxyglutamic acid containing proteins in developing rat bones. Collagen and RelatedResearch, v. 5, p. 273$281,1985$.

BUCHMAN, S.R., OZAKI, W. The ultrastructure and resorptive pattern of cancellous onlay bone grafts in the craniofacial skeleton. Annuals Plastic Surgery, v. 43, p. 49-56, 1999.

CHAUSHU, G. et al. The use of cancellous block allograft for sinus fllor augmentation with simultaneous implant placement in the posterior atrophic maxilla. Jounal Periodontology, V. 80, n. 3, p. 422-428, March. 2009.

CLAYMAN, L. Implant reconstruction of the bone-grafted maxilla: review of the literature and presentation of 8 cases. Journal of Oral and Maxillofacial Surgery, v. 64, n. 4, p. 674-682, Copenhagen, Apr, 2006.

CONTAR, C. M. et al. Maxillary ridge augmentation with fresh-frozen bone allograft. Journal of Oral and Maxillofacial Surgery, v. 67, p. 1280-1285, 2009.

COSTA, O. R.; VEINSTEIN, F. J. Injertos oseos em regeneracíon peridontal. Ver. Asoc. Odont. Argent., v. 82, p. 117-125, 1994.

DE BOER, H. The history of bone grafts. Clin Orthop Relat Res, v. 292, 1968.

DOUGLAS, C.R., DOUGLAS, N.A. Fisiologia do osso. In: Douglas, C.R. Patologia Oral, vol. II, $1^{\text {a }}$. reimpressão, Pancast, cap. 51, p. 201-245, 2000.

DUCY, P. et al. Increased bone formation in osteocalcin-deficient mice. Nature, v. 382, p. 448-452, 1996. 
ELLIS III, E., SINN, D.P. Use of homologous bone in maxillofacial surgery. Journal of Oral and Maxillofacial Surgery, v. 51, p. 1181-1193, 1993.

FARIA, P.E.P. et al. Immunohistochemical, tomographic and histologic study on onlay iliac grafts remodeling. Clinical Oral Implants Research, v. 19, p. 393-401, 2008.

GAMRADT, S.C., LIEBERMAN, J.R. Bone graft for revision hip arthroplasty: biology and future applications. Clinical Orthopaedics and Related Research, v. 417, p. 183-194, Dec, 2003.

GARBIN JÚNIOR, E.A. A avaliação do processo de reparo do osso alógeno fresco congelado, em bloco, e do enxerto ósseo autógeno: análise histológica, histométrica e imunoistoquímica em coelhos. 2008. 85f. Tese (Doutorado) - Universidade Estadual Paulista. Faculdade de Odontologia, Araçatuba.

GARNERO, P.; DELMAS, P. D. (1999) Laboratory assessment of postmenopausal osteoporosis. In: Seibel, M. J., Robins, S. P. \& Bilezikian, J. P. Dynamics of bone and cartilage metabolism, $1^{\text {st }}$ edition, p. 465-477. San Diego: Academic Press.

INTINI, G. et al. A comparative analysis of bone formation induced by human demineralized freeze-dried bone and enamel matrix derivative in rat calvaria criticalsize bone defects. Journal Periontology, v. 79, n. 4, p. 1217-1224, 2008.

ITO, H. et al. Remodeling of cortical bone allografts mediated by adherent rAAVRANKL and VEGF gene therapy. Nature Medicine, v. 11, n. 3, p. 291-297, Feb, 2005.

HYATT, G.W. Fundamentals in the use and preservation of homogenous bone. United Stated Armed Forces Medical Journal, v. 1, n. 8, p. 841-852, 1950.

HYATT, G.W. et al. New methods for preserving bone, skin, and blood vessels. Postgraduated Medicine, v. 12, n. 3, p. 239-254, 1952.

HOFBAUER, L. C. Pathophysiology of RANK ligand (RANKL) and osteoprotegerin (OPG). Ann Endocrinol , v. 67, n. 2, p. 139-141, 2006.

HOLMQUIST, P. et al. A new technique for reconstruction of the atrophied narrow alveolar crest in the maxilla using morselized impacted bone allograft and later placement of dental implants. Clinical Implant Dentistry and Related Research, v. 10, n. 2, p. 86-93, 2008. 
HOLTZCLAW, D. et al. The safety of bone allografts used un Dentistry: a review. Journal American Dental Association, v. 139, p. 1192-1199, 2008.

JOHNSON, L. Freeze-dried bone allografts in endosseous implant defects a preliminary report of two re-opened cases. Journal Oral Implantology, v. 9, n. 2, p. 217-228, 1980.

KAPPE, T. et al. Infections after bone allografts surgery: a prospective study by a hospital bone bank using frozen femoral heads from living donors. Cell Tissue Bank, DOI 10.1007/s10561-009-9140-5, 2009.

KEITH, J.D. et al. Clinical and histologic evaluation of a mineralized block allograft: results from the developmental period (2001-2004). International Journal Periodontics Restorative Dentistry, v. 26, n. 4, p. 321-327, Aug. 2006.

KHAN, N.S. et al. The biology of bone grafting. The Journal of the American Academy of Orthopaedic Surgery, v. 13, n. 1, p. 77-86, Jan-Feb, 2005.

KLONGNOI, B. et al. Influence of platelet-rich plasma on a bioglass and autogenous bone in sinus augmentation. An explorative study. Clinical Oral Implants Research, v. 17, n. 3, p. 312-320, Copenhagen, Jun. 2006a.

KLONGNOI, B. et al. Lack of beneficial effects of platelet-rich plasma on sinus augmentation using a fluorohydroxyapatite or autogenous bone: an explorative study. Journal of Clinical Periodontology, v. 33, n. 7, p. 500-509, Munksgaard, Jun. 2006b.

KLUGER, R. et al. Removal of the surface layers of human cortical bone allografts restores in vitro osteoclast function reduced by processing and frozen storage. Bone, $v$. 32, n. 3, p. 291-296, New York, Mar. 2003.

LAURIE, S.W. et al. Donor-site morbidity after harvesting rib and iliac bone. Plastic and Reconstructive Surgery, v. 73, n. 6, p. 933-38, 1984.

LEONETTI, J.A., KOUP, R. Localized maxillary ridge augmentation with a block allografts for dental implant placement: case reports. Implant Dentistry, v. 12, n. 3, p. 217-226, 2003.

LIU, F. A human Mad protein acting as a BMP-regulated transcriptional activator. Nature, v. 13, n. 381 (6583), p. 620-623, 1996. 
LIZUKA, T. et al. Extensive augmentation of the alveolar ridge using autogenous calvarial split bone grafts for dental rehabilitation. Clinical Oral Implants Research, v. 15, p. 607-615, 2004.

MANNAI, C. Early implant loading in severely resorbed maxilla using xenograft, autograft and platelet-rich plasma in 97 patients. Journal of Oral and Maxillofacial Surgery, v. 64, n. 9, p. 1420-1426, Copenhagen, Set. 2006.

MARTHY, S., RICHTER, M. Human immunodeficiency virus activity in rib allografts. Journal of Oral and Maxillofacial Surgery, v. 56, n. 4, p. 474-476, 1998.

MISH, C.M. Comparison of intraoral donor sites for onlay grafting prior to implant placement. International Journal of Oral and Maxillofacial Surgery, v. 12, p. 767-76, 1997.

MISCH, C. E., DIETSH, F. Bone grafting materials in implant dentistry. Implant. Dent., v. 2, p.158-67, 1993.

MONOV, G. et al. The effect of platelet-rich plasma upon implant stability measured by resonance frequency analysis in the lower anterior mandibles. A pilot study. Clinical Oral Implants Research. v. 16, n. 4, p. 461-465, Copenhagen, Ago. 2005

MONTAZEM, A. et al. The mandibular symphysis as a donor site in maxillofacial bone grafting: A quantitative anatomic study. Journal of Oral and Maxillofacial Surgery, v. 58, n. 12, p. 1368-71, 2000.

NGUYEN, H. et al. Sterilization of allograft bone: is 25 kGy the gold standard for gamma irradiation? Cell Tissue Banking, v. 8, n. 2, p. 81-91, 2007.

NISSAN, J. et al. Efficacy of cancellous block allograft augmentation prior to implant placement in the posterior atrophic mandible. Clinical Implant Dentistry and Related Research, DOI 10.1111/j.1708-8208.2009.00219.x, 2009.

NISHIGUCHI, $M$. et al. Amelogenin is a negative of osteoclastogenesis via downregulation of RANKL, M-CSF and fibronectin expression in osteoblasts. Archives of Oral Biology, v. 52, n. 3, p. 243-273, Oxford, Mar. 2007.

OHYA, M. et al. Sinus floor elevation applied tissue-engineered bone. Comparative study between mesenchymal stem cells/platelet-rich plasma (PRP) and autogenous bone with PRP complexes in rabbits. Clinical Oral Implants Research, v. 16, n. 5, p. 622-629, Copenhagen, Out. 2005. 
OLIVEIRA NETO, P.J. Estudo comparativo da fixação e integração de enxertos ósseos “onlay” com o uso de n-Butil-2-Cianocrilato ou parafuso de titânio. Estudo histológico, imunohistoquímico e tomográfico em coelhos. 2010. 55f. Dissertação (Mestrado) Universidade de São Paulo. Faculdade de Odontologia, Ribeirão Preto.

OYAMA, T. et al. Efficacy of platelet-rich plasma in alveolar bone grafting. Journal of Oral and Maxillofacial Surgery, v. 62, n. 5, p. 555-558, Copenhagen, Maio. 2004.

OZAKI, W., BUCHMAN, S.R. Volume maintenance of onlay bone grafts in the craniofacial skeleton: micro-architecture versus embryologic origin. Plastic and Reconstructive Surgery, v. 102, p. 291-299, 1998.

PEDROSA JUNIOR, W.F. et al. Immunohistochemical, tomographic and histological study on onlay bone grafts remodeling. Part II: calvarial bone. Clinical Oral Implants Research, v. 20, p. 1254-1264, 2009.

PELEG, M. et al. Maxillary sinus and ridge augmentations using a surface-derived autogenous bone graft. Journal of Oral and Maxillofacial Surgery, v. 62, n. 12, p. 15351544, Copenhagen, Dec. 2004.

PETRUNGARO, P.S., AMAR, S. Localized ridge augmentation with allogenic bloc grafts prior to implants placement: case reports and histologic evaluations. Implant Dentistry, v. 14, n. 2, p. 139-146, 2005.

RAJAN, G.P. et al. Cancellous allograft versus autologous bone grafting for repair of comminuted distal radius fractures: a prospective, randomized trial. The Journal CranioMaxillofacial Trauma, v. 60, n. 6, p. 1322-1329, 2006.

REYNOLDS, M., BOWERS, G. Fate of demineralized freeze-dried bone allografts in human intrabony defects. Journal Periodontology, v. 67, n. 2, p. 150-157, Feb. 1996.

SALAI, M. et al. The effects of prolonged cryopreservation on the biomechanical properties of bone allografts: A microbiological, histological and mechanical study. Cell and Tissue Banking, v. 1, n. 1, p. 69-73, 2000.

SHAND, J.M. et al. Allogeneic bone grafting of calvarial defects: an experimental study in the rabbit. International Journal of Ora and Maxillofacial. Surgery, v. 31, n. 5, p. 525$531,2002$. 
SIMONDS, R.J. et al. Transmission of human immunodeficiency virus type 1 from a seronegative organ and tissue donor. The New England of Journal Medicine, v. 326, n. 11, p. 726-732, 1992.

STEVENSON, S. et al. Factors affecting bone graft incorporation. Clinical Orthopaedics and Related Research, v. 323, p. 66-74, 1996.

SOHN, D.S. et al. Histomorphometric evaluation of mineralized cancellous allograft in the maxillary sinus augmentation: a 4 case report. Implant Dentistry, v. 18, n. 2, p. 172$181,2009$.

TOMFORD, W.W., MANKIN, H.J. Bone banking. Update on methods and materials. The Orthopedic Clinics of North America, v. 30, n. 4, p. 565-570, Oct, 1999.

TOMFORD, W.W. Bone allografts: Past, present and future. Cell and Tissue Banking, v. 1, p. 105-109, 2000.

TONG, L., BUCHMAN, R.S. Facial bone grafts: contemporary science and thought. The Journal of Cranio-maxillofacial Trauma, v. 6, p. 31-41, 2000.

TORREZAN, P.R. et al. Utilização de Homoenxerto congelado para reconstrução em áreas atróficas pré-implante: um relato de caso clínico. Revista Brás Implantodont Prótese Implant, v.10, n. 39, p.201-207, Jul-Set, 2003.

VIROLAINEN, P. et al. 30 years of bone banking at Turku bone bank. Cell Tissue Bank, V. 4, n. 43, 2003.

YAMADA, Y. et al. Tissue-engineered injectable bone regeneration for osseointegrated dental implants. Clinical Oral Implants Research, v. 15, n. 5, p. 589-597, Copenhagen, Out. 2004.

YOUNG, C. et al. A comparative study of anorganic xenogic bone and autogenous bone implants for bone regeneration in rabbits. International Journal of Oral Maxillofacial Implants, v.14, p. 72-76, 1999.

WINSLOW, M. M. et al. Calcineurin/NFAT signaling in osteoblasts regulates bone mass. Developmental Cell, v. 10, n. 6, p. 771-782, Cambridge, Jun. 2006.

ZEITER D. J. et al. The use of a bone block graft from the chin for alveolar ridge augmentation. The International Journal of Periodontics and Restorative Dentistry, v. 20, n. 6, p. 619-627, Dec, 2000. 